\title{
THE RELATION BETWEEN PAYROLL AND INCOME TAX AVOIDANCE
}

by

\author{
Michael Marin \\ A thesis submitted in conformity with the requirements \\ for the degree of Doctor of Philosophy \\ Joseph L. Rotman School of Management \\ University of Toronto
}

(C) Copyright 2021 by Michael Marin 


\title{
The Relation between Payroll and Income Tax Avoidance
}

\author{
Michael Marin \\ Doctor of Philosophy \\ Joseph L. Rotman School of Management \\ University of Toronto \\ 2021
}

\begin{abstract}
Payroll taxes, such as contributions mandated through the Federal Insurance Contributions Act (FICA), represent a considerable expense for businesses and are a large source of government revenue. Considering that employers pay approximately $50 \%$ of FICA, payroll taxes have a material impact on firm profitability. Despite the large cost, little is known about the determinants of payroll tax avoidance. By misclassifying employees as independent contractors, a firm can avoid their portion of FICA contributions and a variety of other employee related costs. This paper utilizes publicly available compliance action data from the Wage and Hour Division (i.e., WHD) of the United States Department of Labor (i.e., DOL) to identify employee misclassification and to empirically identify whether firms that avoid income taxes also avoid payroll taxes. This paper documents two main results. First, income tax avoidance, proxied by CashETR, is positively related to the likelihood of a successful discovery of a Fair Labor Standards Act (i.e., FLSA) violation during a Wage and Hour Division audit. Second, firms reduce their income tax avoidance following the discovery of FLSA violations.
\end{abstract}

Keywords: Tax Planning, Employee Classification, Non-Income Taxes 


\section{Acknowledgements}

I am extremely grateful to my chair, Alexander Edwards, for his mentorship and encouragement throughout my undergraduate, MBA and doctoral studies at Rotman. Few students are as fortunate as I in having such a supportive figure for so long in their academic career. I would also like to thank my committee members Aida Wahid and Baohua Xin for their tremendous guidance and support over the last 5 years. I also want to acknowledge and express my gratitude towards Ole-Kristian Hope and Gordon Richardson for their active involvement during my studies, job search, and for encouraging me to apply to the program. I also appreciate the helpful comments from my external examiner Sean McGuire and the financial support from the Rotman School of Management that made this degree possible.

I want to thank all the current and former Rotman Accounting PhD students and faculty that I have had the pleasure to interact with. Specifically, I want to thank my cohort of Bingxu Fang and Mingyue Zhang. I am also appreciative to Elisa Zuliani who gave me my first opportunity in academia that convinced me to continue in my studies.

This paper has greatly benefited from helpful comments from Andrea Down, Ramy Elitzur, Bingxu Fang, Jody Grewal, Ole-Kristian Hope, Yu Hou, Shushu Jiang, Devan Mescall, Partha Mohanram, Gordon Richardson, Shibin Tang, Dushyant Vyas, Yuchen Wu, and Mingyue Zhang.

Lastly, I would like to dedicate this dissertation to my parents, Eddy and Ornella, my brothers, Marco and Matthew, my fiancée Amanda, and my best friends Peter, Marc, and Matt. Your sacrifices will never be forgotten and are the reason I have been able to pursue what I most enjoy for so long. 


\section{Table of Contents}

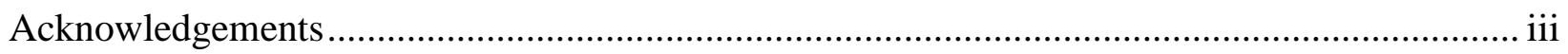

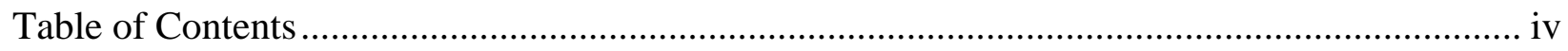

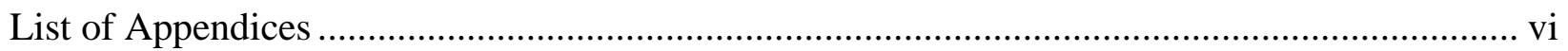

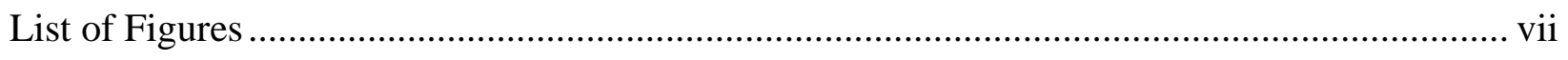

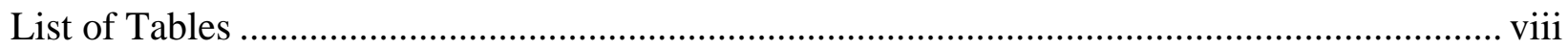

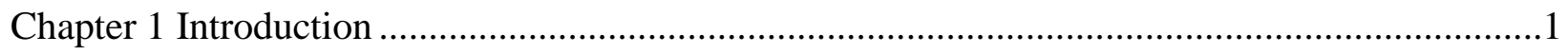

Chapter 2 Institutional Background and Prior Literature ……..................................................

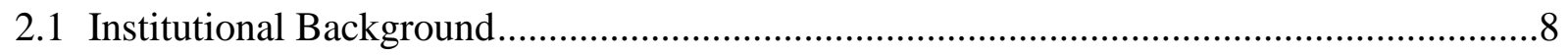

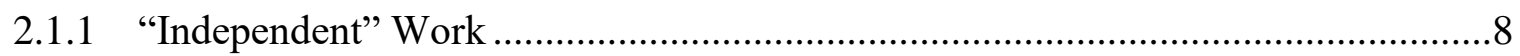

2.1.2 Payroll Taxes ………………………………….........................................10

2.1.3 Misclassification \& Detection........................................................................12

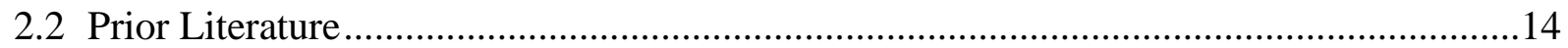

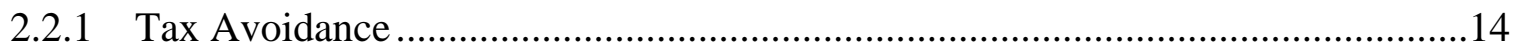

2.2.2 Tax Audits/Enforcement .............................................................................15

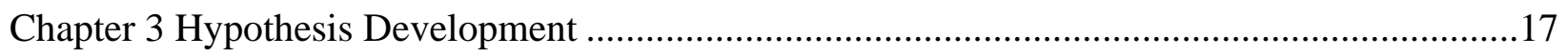

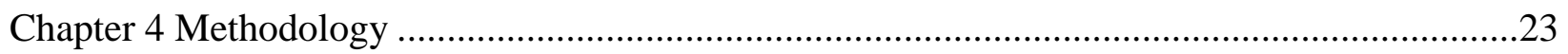

4.1 Measure of Payroll Tax Avoidance ………………......................................................23

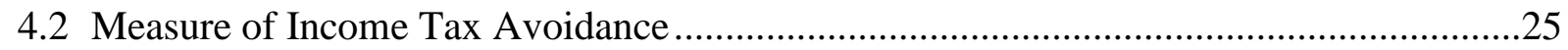

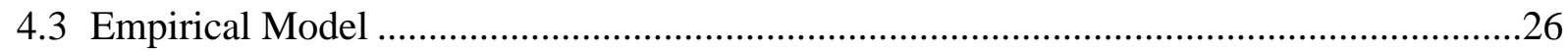

4.3.1 Likelihood of a Successful Employee Misclassification Audit ..............................26

4.3.2 Change in Firm Behavior Post DOL Investigation................................................31

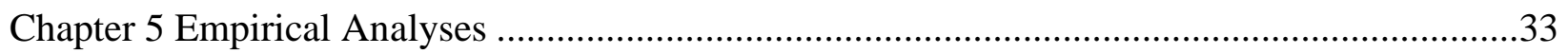

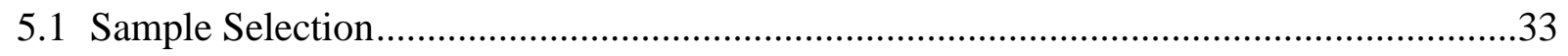

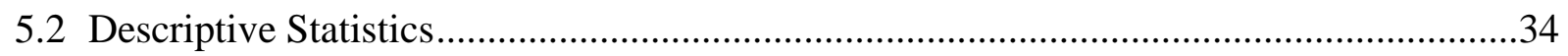




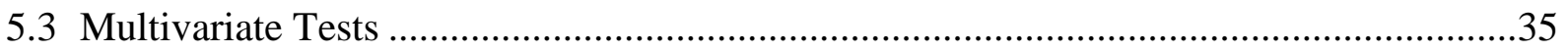

5.3.1 Likelihood of a Successful Employee Misclassification Audit ...............................35

5.3.2 Change in Firm Tax Avoidance Behavior Post DOL Investigation ........................37

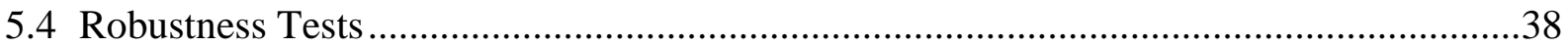

5.4.1 Validation of Misclassification Proxy ………………………….......................38

5.4.2 Sample Partitions ..............................................................................................

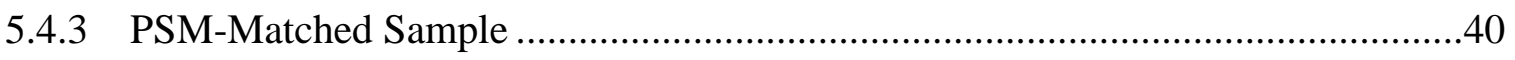

5.4.4 Alternative Control Group ................................................................................41

5.4.5 Alternative Treatment Group ........................................................................41

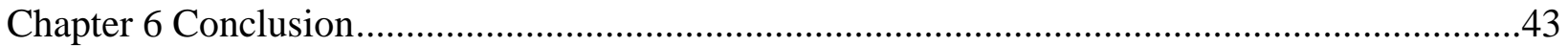

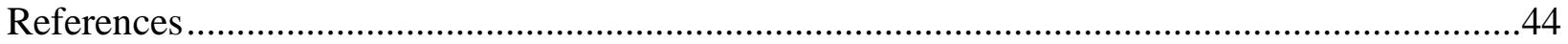

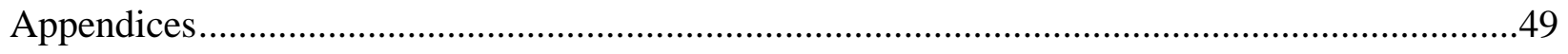

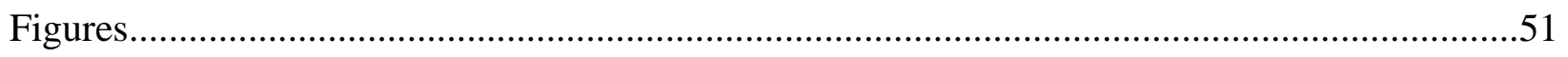

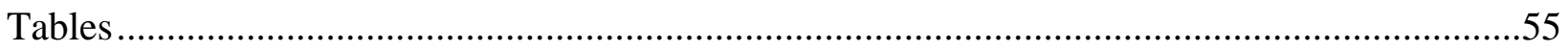




\section{List of Appendices}

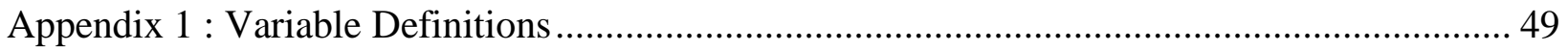




\section{List of Figures}

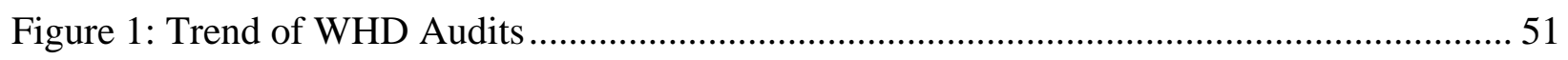

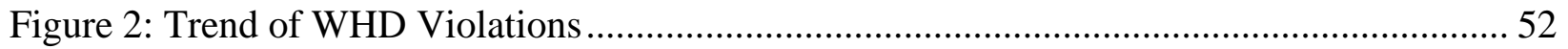

Figure 3: Industry Distribution of WHD Audits ............................................................. 53

Figure 4: Industry Distribution of FLSA Violations....................................................... 54 


\section{List of Tables}

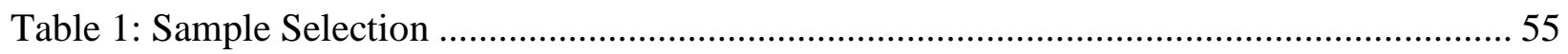

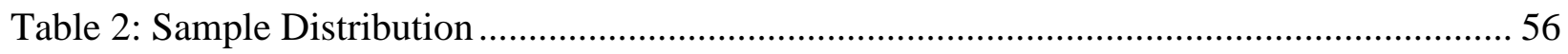

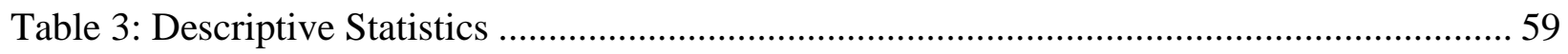

Table 4: First Stage Model of the Determinants of a WHD Audit ................................................... 66

Table 5: Second Stage Model of the Determinants of a Violation being Detected ....................... 68

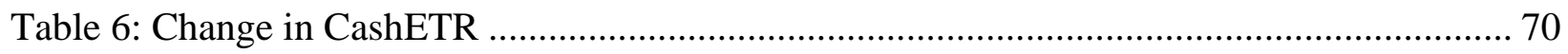

Table 7: Change in Employees/Sales following Violations ...................................................... 71

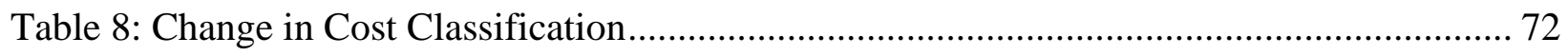

Table 9: Cross-Sectional Test: Likelihood of Tax Avoidance Sample Partition........................... 75

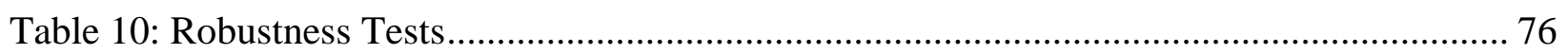




\section{Chapter 1 \\ Introduction}

"Workers classified as employees cost 30-40\% more than contractors because companies must pay federal income, Social Security, and Medicare taxes for

each employee, as well as unemployment insurance, and the cost of benefits, such as health insurance" (Mulcahy 2019).

Employee misclassification is the incorrect identification of workers as independent contractors instead of as employees, or as employees instead of independent contractors. Workers designated as independent contractors receive a Form 1099 (i.e., income from self-employment) and the employer avoids withholding payroll taxes, remitting their share of Social Security and Medicare tax, and any contributions related to unemployment insurance/workers' compensation. ${ }^{12}$ While the issue of employee misclassification is not new, the recent rise of the gig economy has brought increased attention to this issue from policymakers, activists, and the media. ${ }^{3}$ Additionally, several high-profile class action lawsuits involving Uber, Microsoft, FedEx, Lyft, and Citigroup, among others, have increased the salience of the issue to the general public. Payroll taxes represent a significantly larger share of tax revenue then corporate taxes and are the second-largest source of tax revenues after personal taxes. ${ }^{4}$ While prior academic literature devotes considerable attention, time, and resources to the notion of unfair and aggressive income tax avoidance, less is

\footnotetext{
${ }^{1}$ In contrast, properly classified employees receive a Form W-2 for which the employer withholds payroll taxes.

${ }^{2}$ In Canada, a contractor or freelancer will receive a T4A slip from each of their clients for the jobs completed within the specified tax period. In contrast, an employee will receive a T4.

3 The Gig economy is based on flexible, temporary, or freelance jobs, often involving connecting with clients or customers through an online platform.

${ }^{4}$ https://www.taxpolicycenter.org/briefing-book/what-are-sources-revenue-federal-government
} 
known about payroll tax avoidance and how these types of behavior relate. The purpose of this paper is to identify the determinants of payroll tax avoidance, and to establish whether a relation exists between income and payroll tax avoidance. This will help determine whether payroll and income taxes can be considered as complements or as substitutes.

Payroll taxes include those taxes deducted from an employee's wages and those taxes paid by the employer based on the employee's wages. ${ }^{5}$ Payroll taxes account for a significant portion of IRS collections revenue. In 2019, individual income taxes withheld (37.9\%), and Federal Insurance Contributions Act (FICA) taxes (31.7\%) account for $69.6 \%$ of the total IRS collections. After accounting for refunds, FICA taxes represent $36.3 \%$ of the net IRS collections compared to just $7.3 \%$ for business income taxes. For simplicity, if one assumes that employers pay $50 \%$ of all FICA contributions, payroll taxes paid by employers represent $18.15 \%$ of net IRS collections. ${ }^{6}$ Considering the difference in IRS percentages and the large literature addressing business income taxes, the relative sparsity of literature addressing payroll taxes is surprising. Even further, although not remitted to the IRS, unemployment taxes paid to the state on employee wages would add additional payroll tax costs to employers. ${ }^{7}$

The Scholes-Wolfson framework for effective tax planning suggests that all parties, all taxes, and all costs must be considered in evaluating tax management decisions (Erickson et al. 2020). Given that payroll taxes are costly, profit insensitive, and administratively burdensome

\footnotetext{
${ }^{5}$ For the purposes of my research question, I am interested in the payroll taxes that are the responsibility of the employer (i.e., the employer share of FICA). In other words, I am interested in the taxes that a firm can avoid through misclassification.

${ }^{6}$ It is slightly less than $50 \%$ because wages paid in excess of $\$ 200,000$ are subject to an extra $0.9 \%$ Medicare tax that is the sole responsibility of employees.

${ }^{7}$ State unemployment tax is a percentage of an employee's wages. Each state sets a different range of tax rates that is determined based on industry, how many former employees received unemployment benefits, and experience.
} 
(Cruz 2019), the employer's share of payroll taxes is likely an important managerial consideration. Although independent contracting can benefit workers and businesses, some employers intentionally misclassify employees. While it is not clear ex-ante that the use of independent contractors reduces the total labor cost, employee misclassification could represent a managerial decision to avoid payroll taxes. It is possible that some employers mistakenly misclassify employees due to ambiguous, and sometimes differing, criteria in determining employee status between the Department of Labor, IRS, and states (Donahue, Lamare, and Kotler 2007). However, it is also likely that some misclassification is an intentional strategy. If caught, firms that misclassify employees can be held responsible for paying back-taxes and interest on employees' wages, and for their portion of FICA taxes. Even further, if the misclassification is determined to be intentional, there can be criminal and civil penalties.

While misclassification clearly impacts the "employee", through incorrect payment of wages, absence of benefits, and increased employee risk exposure (Weil 2017), there are other negative consequences for the economy. Governments receive less tax revenue and legitimate businesses struggle to compete against companies that intentionally misclassify employees as a source of competitive advantage (Chau and Artecona 2017). The US Treasury estimates that forcing employers to properly classify their workers and tightening other (i.e., safe harbour) restrictions on classification, would yield $\$ 8.71$ billion in added tax revenue over the next decade (Loten and Maltby 2013). Given this estimate was made prior to the rise of the gig economy, it is likely that this amount is now much higher.

While not the focus of this study, another relevant issue is whether misclassified employees themselves reduce their overall tax burden. This could be an avenue for future research given the high noncompliance rate associated with self-employed income (Slemrod 2007). This could also 
explain why some misclassified workers do not report the misclassification to authorities. In 2009, the treasury inspector general estimated that employee misclassification costs the US \$54 billion in underpayment of employment taxes versus \$15 billion in unpaid FICA and unemployment taxes (Treasury Inspector General for Tax Administration 2013). While misclassified workers may be able to increase their after-tax earnings if considered independent, as highlighted from the recent Covid-19 Pandemic, misclassified workers cannot access federal and state benefits when they need them.

My research question is centered on the notion that tax avoidance should relate to all taxes. While the literature has primarily focused on income tax avoidance, all taxes that have a material impact on profitability should be effectively managed by firms. The National Conference of State Legislatures estimates that a business can save 30 percent of their labor costs by using independent contractors rather than employees (National Conference of State Legislatures 2014). ${ }^{8}$ Employee misclassification represents a simple (yet effective) mechanism for payroll tax avoidance. However, it should be noted that while misclassification may be easy to implement, it is both an illegal strategy and costly if the classification is proven to be incorrect. ${ }^{9}$ Misclassification may lead to monetary fines such as back taxes for misclassified workers, and may also result in reputation damage, criminal/civil penalties and/or sanctions (Zaino 2017).

\footnotetext{
${ }^{8}$ Many firms will legitimately hire independent contractors for its increased flexibility, for specific skill sets, and to reduce overhead.

${ }^{9}$ While the DOL and IRS consider written agreements as a factor for proper employee classification, they also consider the reality of the situation. While legitimate independent contracting exists, I am interested in intentional misclassification. For this reason, I use Department of Labor Wage and Hour Division Audits that uncover Fair Labor Standard Act Violations as a proxy for intentional misclassification.
} 
An issue with the study of payroll taxes is that these taxes cannot be identified from publicly available financial accounting data. Payroll taxes are allocated with wages/salaries into different income statement accounts. For this reason, this paper relies on publicly available Wage and Hour Compliance Action Data from the Wage and Hour Division (WHD) of the US Department of Labor (DOL). This dataset includes any violations of the Fair Labor Standards Act (FLSA) which establishes wage and overtime protections for employees, and not for independent contractors.

To estimate the determinants of payroll tax avoidance through employee misclassification, I estimate the determinants on the subsample of firms that have had WHD audits. However, given that the WHD audit itself is likely not random, I control for the potential sample selection issue through the use of a Heckman two-step correction procedure (Heckman 1979). In the first stage, I model the likelihood of a firm being subjected to a WHD audit. In the second stage, I estimate the likelihood of the WHD audit discovering employee misclassification. I find that firms with higher cash income taxes are more likely to misclassify employees. This result is consistent with the notion that firms without the ability to avoid income taxes look for other opportunities to reduce their total tax expense. Furthermore, using a difference-in-difference research design, I document that following detection of misclassification, firms increase their cash income taxes paid by 2.1 percent. This result suggests that, despite having higher cash taxes paid, these firms were still taking aggressive tax positions and chose to reduce their aggressiveness following a successful WHD audit.

My findings are robust to a number of specifications. First, in my main specification the control group is represented by firms subjected to a WHD audit but for which no labor violations were found. The results remain consistent when I consider all firms without FLSA violations as 
the control group. Second, while some employers misclassify employees as independent contractors, other employers misclassify employees as being exempt from overtime. While both misclassifications are FLSA violations, I repeat the analysis for the subset of firms that have fines related to minimum wage transgressions instead of overtime wages. Third, to address potential concerns that firms in the treatment group and the control group might not be comparable, I re-estimate the model using industry-year matched pairs of treatment and control firms. Taken together, these robustness tests provide comfort that the findings are not due to research design, and that the proxy for employee misclassification (i.e., FLSA violations) are indicative of employees being incorrectly labeled as independent contractors.

This paper makes several contributions to the literature. First, little is known about payroll tax avoidance because, even with proprietary data, payroll tax avoidance is difficult to explicitly identify. At least anecdotally, firms misclassify employees to avoid their share of payroll taxes (Mulcahy 2019). Publicly available Department of Labor Wage and Hour Division audits uncover labor violations and require no subjectivity from the researcher. Thus, the use of these audits as a proxy for payroll tax avoidance can circumvent the issue of identification and aid in the discovery of the determinants and consequences of payroll tax avoidance. By identifying the determinants of misclassification, the government can improve its enforcement initiatives. Second, albeit related to the above, although non-income taxes are economically significant, the avoidance of these taxes is a relatively unexplored research area (Wang et al. 2019). By establishing a relationship between payroll and income tax avoidance, I provide evidence consistent with the Scholes-Wolfson framework whereby firms consider multiple types of taxes in their decision making. The fact that a relationship exists between different types of taxes further exacerbates the lost government revenue problem. Third, this paper answers the call for studies that identify specific transactions 
and techniques that firms employ to generate tax savings (Wilde and Wilson 2018). Employee misclassification is an approach to avoid payroll taxes. Given the difficulty in explicitly identifying any type of avoidance activity, if the avoidance of payroll taxes may be related to other questionable tax behavior, authorities may want to devote increased scrutiny to the misclassifying firms to discover other types of avoidance strategies.

The remainder of this paper is structured as follows: Section 2 provides background information, Section 3 develops the hypotheses, Section 4 describes the data and outlines the empirical design, Section 5 presents the empirical results and a discussion of the findings, and Section 6 concludes. 


\section{Chapter 2 \\ Institutional Background and Prior Literature}

In this chapter, I provide a summary of the relevant institutional details related to independent work arrangements, payroll tax deductions, and employee misclassification/detection. I then summarize the extant literature that is most closely related to the study of my research question.

\subsection{Institutional Background}

In this subsection, I motivate the study by highlighting the prevalence of independent contractors in the economy, outline the key factors, criteria, and ambiguity when determining worker status, and highlight the tax differences that arise in different working arrangements.

\subsection{1 "Independent" Work}

While many of the tests are similar in nature, the IRS, the Department of Labor, and each state have their own specific tests to determine whether an individual should be classified as an independent contractor or as an employee. The DOL uses an economic reality test whereby it considers the degree of control over the work and the worker's opportunity for profit. For the IRS, the general rule is that an individual is an independent contractor if the payer has the right to control or direct only the result of the work, not what will be done or how it will be done (IRS 2020). Specifically, the IRS considers behavioral control, financial control, and the type of relationship between the parties. Behavioral control includes facts that show whether the business has a right to direct and control how a worker performs a task, financial control includes facts that show whether the business has a right to control the business aspects of the worker's job, and the type of relationship includes the permanency of the relationship and the extent to which services performed are a key aspect of the regular business of the company (IRS 2020). Using Uber as an 
example, in a 2019 memo the National Labor Relations Board argued that Uber drivers are independent because they have "significant entrepreneurial opportunity by virtue of their near complete control of their cars and work schedules, together with freedom to choose log-in locations and to work for competitors of Uber." (Scheiber 2019). ${ }^{10}$

The US Bureau of Labor Statistics defines contingent workers as "those who do not have an implicit or explicit contract for continuing employment." Such cases include independent contractors, on-call workers, temporary help agency workers, and workers provided by contract firms. According to the US Bureau of Labor, in May 2017, there were 10.6 million independent contractors, 2.6 million on-call workers, 1.4 million temporary help agency workers, and 933,000 workers provided by contract firms (US Bureau of Labor Statistics 2018) ${ }^{11}$. Unlike the other categories, independent contractors are legally self-employed and are thus subject to different tax and labor laws relative to traditional, or other alternative/contingent, employment (Collins et al. 2019). ${ }^{12}$ In 2016, one study estimated that $8 \%$ of the US workforce consists of independent contractors. ${ }^{13}$ As a caveat, the estimates do not include workers who have a traditional main job but engage in alternative work to supplement their income. It is well established that the gig economy serves as a source of secondary income for many households (Koustas 2019). In a recent study by the McKinsey Global Institute, 8,000 respondents across Europe and the United States

\footnotetext{
10 On November 3, 2020, California voters approved Proposition 22, a ballot measure that allows gig economy companies to continue treating drivers as independent contractors.

${ }^{11}$ In the same report, there were 5.9 million contingent workers. Contingent workers are persons who do not expect their jobs to last or who report that their jobs are temporary. While some workers are both contingent and working in an alternative arrangement, they are measured separately.

12 While contingent employment is not "traditional", contingent employees receive a W-2 tax form rather than a 1099 MISC.

13 https://www.cfo.com/people/2019/09/state-laws-cloud-the-use-of-independent-contractors/
} 
were surveyed about their income in the past 12 months. The results suggest that 20 to 30 percent of the working-age population engage in some form of independent work (Bughin et al. 2016).

It is important to note that being considered an independent contractor does not necessarily represent employee misclassification. Many workers self-select into independent work for its increased flexibility, control, and independence relative to traditional employment. Additionally, many firms legitimately structure their business model to rely on independent contractors instead of employees. ${ }^{14}$

\subsubsection{Payroll Taxes}

Companies are legally responsible for paying a portion of employee payroll taxes. As stipulated by FICA, an employer must pay Social Security (6.2\% on wages up to $\$ 137,700)$, and the Medicare Tax $(1.45 \%$ on wages up to $\$ 200,000)$. These rates can be found in IRS Publication 15: (Circular E), Employer's Tax Guide (Internal Revenue Service 2020). Independent contractors pay both the employer and employee portions of the FICA tax (i.e., 15.3\%) as outlined by the SelfEmployed Contributions Act (SECA) but can deduct 50\% on their personal tax return. Additionally, employers are responsible for federal and state unemployment taxes (FUTA, SUTA), workers compensation insurance, and for withholding and remitting employee income taxes to the appropriate authority. ${ }^{15}$ While there are other benefit costs paid to employees, that are often not paid to independent contractors, as mandated by union agreements or as incentives to attract/retain workers, for the purposes of this paper, I focus on the legal requirements imposed by statute on all

\footnotetext{
${ }^{14}$ Fiverr and Upwork are two companies that provide a marketplace for freelance services.

152020 FUTA tax rate is $6 \%$, applied to the first $\$ 7,000$ earned by each employee. $(\$ 7,000 * 6 \%=\$ 420)$
} 
firms and not on the additional benefits that affect a smaller subset of businesses. ${ }^{16}$ I argue that this is appropriate because additional deductions/benefits would increase the cost for each employee and thus further incentivize misclassification. As a robustness test (see Section 5.4.5), I separate FLSA violations into those that are more likely motivated by reduced payroll taxes, and those that are more likely motivated by reduced labor costs to see if there is a differing effect on my research question.

According to IRS administrative data, in 2019, FICA contributions amounted to $31.7 \%$ of all IRS collections. ${ }^{17}$ For illustrative purposes, corporate income taxes represent $7.7 \%$ (IRS 2020). As an example of payroll taxes that firms pay, consider an employee earning $\$ 100,000$. As an independent contractor, the cost to an employer is simply the $\$ 100,000$ wage. However, if classified as an employee, the cost is an additional $\$ 7,650(6.2 \%+1.45 \%)$ in Social Security and Medicare taxes. There are also administrative costs associated with other income tax withholding, other voluntary benefits, inflexibility costs, and unemployment insurance premiums. ${ }^{18}$ While the $\$ 7,650$ may not seem high, the cost can become material and is for each employee (at $\$ 100,000)$. While legitimate independent contractors may charge higher fees to compensate for lost benefits, for the purposes of this study, I am interested in employee misclassification. Therefore, the above example holds for intentional misclassifications. An intentional misclassification, provided it is

\footnotetext{
16 The most popularly offered employee benefits include: Health Insurance, Life Insurance, Dental Insurance, Pension Plans, Flexible Spending Accounts (FSAs) or Health Savings Accounts (HSAs), Paid Vacation and Sick Time, Paid Holidays, Paid Medical Leave, Flexible Schedules, and Education Assistance.

17 Self-Employment Insurance Contributions Act (SECA) are separate from the 31.74\%. Self-Employed FICA account for $1.8 \%$ of IRS collections.

${ }^{18}$ There are many benefits and allowances that can be provided to an employee on a non-taxable basis. The most common voluntary benefits include: Cell Phone and Internet Services, Education and Professional Development Costs, Professional Dues, Recreational Facilities and Club Dues, Gifts and Awards, Automobile Allowances, Counselling Services, Loyalty Points, Private Health Services Plan, and Short-Term/Long-Term Disability Insurance. These benefits are not usually awarded to independent contractors.
} 
not detected, will yield significant cost savings to an employer $(\$ 7,650$ per misclassified employee in my example).

\subsubsection{Misclassification \& Detection}

Employee misclassification is associated with labor and tax law violations (TIJTA 2018).

While many assume that the Internal Revenue Service (IRS) or Department of Labor (DOL) is primarily responsible for the detection and punishment of misclassification, neither is particularly effective. While taxpayers voluntarily pay about 81.7 percent of their tax liability, tax enforcement, mostly via audits, helps to recover an additional $2 \%$ of the total tax liability and the remaining 16.3 percent is lost (Debacker et al. 2018). As for the DOL, it normally only handles cases where there is the possibility that many workers have been misclassified and there has been a substantial loss to the federal and/or state government (Messina et al. 2019).

While it is likely that the DOL or IRS can identify employee misclassification through specific or targeted audits, proper classification is largely determined from other non-random mechanisms. If an employee believes that they are misclassified, there are several legal recourse options available. First, an employee may report to the state labor office for violations regarding unemployment insurance, worker's compensation, and tax fraud. Second, an employee may report a FLSA violation to the DOL Wage and Hour Division (WHD). Third, an employee may report suspected tax fraud to the IRS by using Form 3949-A. Fourth, an employee/employer may file an IRS Form SS-8 for a determination of worker status. Any of these approaches will work and it is unclear which approach a misclassified employee would take in each specific circumstance. For the purposes of this study, I rely on the US Department of Labor Wage and Hour Division complaints because the data is publicly available. In many cases, an employee would contact a lawyer who in turn would suggest the most appropriate form of action. 
The Wage and Hour Division of the Department of Labor enforces the Fair Labor Standards Act (FLSA) which provides employees with minimum wage, overtime pay, and child labor standards/protections. ${ }^{19}$ WHD FLSA investigations detect and address misclassification primarily when responding to complaints from workers (United States Government Accountability Office 2006). 75 percent of all WHD investigations are initiated by worker complaints (Weil 2010). Applying the FLSA's definition, workers who are economically dependent on the business of the employer, regardless of skill level, are employees. Conversely, independent contractors are workers with economic independence who are in business for themselves (WHD 2014). Fair Labor Standards Act Enforcement Statistics indicate that from FY 2009-2019 there were 239,437 WHD investigations that resulted in FLSA violations. In total, these violations impacted 3,027,957 employees who were awarded nearly $\$ 2$ billion dollars in back wages. The FLSA gives the Department of Labor the authority to recover back wages and liquidated damages (to be paid to employees), and to assess civil money penalties (to be paid to the government), in instances of violations (United States Department of Labor 2015).

There are reasons why a misclassified employee would not complain to the IRS or Department of Labor. For one, employees may be uneducated/unaware of the misclassification or fear potential job loss. It is also possible that an employee may prefer to be misclassified since employees do not have the same tax advantages. While unreimbursed employee business expenses are limited in deductibility, an independent contractor can write off all reasonable and necessary business expenses that would reduce their tax payments to receive higher after-tax remuneration (Parrish 2013).

\footnotetext{
${ }^{19}$ WHD also enforces a variety of other Acts including: Family and Medical Leave Act, Service Contract Act, Migrant and Seasonal Agricultural Worker Protection Act, Davis-Bacon and Related Act, etc.
} 


\subsection{Prior Literature}

In this subsection, I highlight the existing literature that is closely related to tax avoidance and tax enforcement as shown in different management and economics disciplines.

\subsubsection{Tax Avoidance}

Given that the Scholes-Wolfson framework for effective tax planning suggests that all parties, all taxes, and all costs must be considered in evaluating tax management decisions, it is likely that payroll taxes are an important consideration to firms. However, despite the large cost associated with payroll taxes, payroll tax avoidance has not been well documented in the literature. Following Hanlon and Heitzman (2010), tax avoidance can be defined as the reduction of explicit taxes. Explicit taxes are any tax levied and collected by the government. These taxes can include, but are not limited to income taxes, payroll taxes, property taxes, sales taxes, and capital gains.

While significant research exists regarding the mechanisms and determinants of corporate income tax avoidance (see Wilde and Wilson (2018) for a comprehensive review), there has been little research regarding non-income-based taxes (Dyreng and Maydew 2018). This is because while income taxes are reported in financial statements, other corporate tax payments, such as payroll taxes, are often hidden and/or difficult to explicitly identify (Christensen, Cline, and Neubig 2001).

Most closely related to this study, is Robinson (2012) who, using Bureau of Economic Analysis data, finds that firms that avoid income taxes also appear to avoid non-income (i.e., employer contributions and taxes other than income/payroll) taxes. However, the specific mechanisms of the non-income tax avoidance are not clear. Further, the measure of non-income tax avoidance (i.e., the sum of other taxes and employer contributions scaled by assets) may not 
be indicative of actual non-income tax avoidance. Firms operate across jurisdictions that each have different types of non-income taxes assessed at different rates. This implies that there is no benchmark to assess the amount of non-income taxes firms are avoiding (Drake et al. 2018). Regarding payroll taxes, it is difficult to explicitly identify the number of employees, the number of independent contractors, or the total compensation expense. ${ }^{20}$ In that sense, estimating the total amount of payroll taxes paid, or an appropriate benchmark, is extremely difficult without confidential or proprietary data.

In their comprehensive review of the tax avoidance literature, Wilde and Wilson (2018) call for studies that identify specific transactions and techniques that firms employ to generate tax savings. The authors argue that it is difficult to identify specific types of activities or tax planning mechanisms because tax planning activities are not publicly observable. Misclassification is one potential and simple way to reduce payroll taxes and could explain why $10 \%$ to $20 \%$ of employers misclassify at least one employee (Carré 2015). One can argue that misclassification is an easier strategy (albeit illegal) to implement and employ relative to other documented avoidance mechanisms including: shifting income across countries and states (Gupta and Mills 2002; Dyreng and Lindsey 2009), engaging in tax shelters (Wilson 2009), or engaging in complex financial arrangements (Engel et al. 1999).

\subsubsection{Tax Audits/Enforcement}

While corporations deal with a variety of different laws and regulations, it is up to the government to enforce them. Since enforcing laws is expensive, governmental agencies will

\footnotetext{
20 The number of employees is available on Compustat (emp) and represents the number of company workers as reported to shareholders. Using the Compustat universe, from 2000-2019, this figure is reported for $68.77 \%$ of firmyear observations.
} 
inspect for compliance through periodic or targeted audits. Analytical research shows that the threat of enforcement should deter tax avoidance (Allingham and Sandmo 1972).

While Hoopes, Mescall, and Pittman (2012) document that US public firms undertake less aggressive tax positions when tax enforcement is stricter, it is not explicitly clear how tax authorities select which firms to audit and what the impact, if any, is of such audits. Naturally, while prior research can infer or predict enforcement, the government will not identify its own criteria because doing so would cause firms to systematically alter their behaviors to avoid enforcement. Given the information sensitivity, tax authorities also rarely reveal which firms have been subject to a tax audit (Li, Pittman, and Wang 2019). While it may not be clear which or why firms are audited, it is understood that tax audits are not random. There are likely some specific characteristics that cause the firm to be selected for a tax audit.

Nessa et al. (2020) examine the impact of IRS resources on the tax enforcement process to document that the IRS reduces its rate of audit and the incidence/magnitude of proposed deficiencies when faced with fewer resources. From 2009-2018, the IRS Budget \& Workforce has been reduced by $14.4 \%$ and $20.6 \%$ respectfully (Internal Revenue Service 2019). The findings of this paper are especially relevant given the recent resource reductions experienced by the IRS. 


\section{Chapter 3 \\ Hypothesis Development}

Tax compliance is largely determined by the trade-off between the relevant costs and the relevant benefits granted by taking a specific tax position. Each firm considers the direct benefits of tax avoidance against the associated non-tax costs to derive its own unique level of optimal tax avoidance (Kim et al. 2019). The economics literature suggests that individual tax compliance is determined by the probability of detection, the cost of the punishment, and the risk aversion of the individual (Allingham and Sandmo 1972). Unlike individual tax compliance, corporate tax compliance decisions are made by an agent (Slemrod 2007). As such, for management to avoid taxes it must be that their total compensation is measured on an after-tax basis and expected firm profits are substantially greater compared to reporting the correct amount of taxes (Chen and Chu 2005). While these theoretical models specifically target tax evasion (or illegal) strategies, they can be applied to firms that engage in aggressive tax strategies, regardless of the type of tax, that may or may not be legal.

Given these incentives, it is likely that firms that would consider engaging in corporate income tax avoidance, may also consider non-income tax avoidance. Theoretically, the risk aversion of the firm and compensation incentive contracts offered to management will also lend themselves to non-income tax planning. It is likely that firms trade-off the different types of taxes that they can minimize. If an agent is remunerated based on after-tax cash flow, like corporate income taxes, payroll tax reduction would be incentivized. Furthermore, if managers are compensated on pre-tax performance, payroll taxes are a pre-tax expense and are thus incentivized as well. Additionally, an argument can be made that the threat of detection and punishment related 
to payroll tax avoidance is lower than for income taxes because unlike statutory rates, there is no appropriate benchmark to compare payroll taxes against (Drake et al. 2018).

Several studies examine the relationship between corporate social responsibility (CSR) and tax avoidance. CSR can be defined as the commitment to behave ethically, to contribute to economic development, and to improve society. Given that taxes fund government expenditures on public goods and services, there is a reason to believe that more socially responsible firms will engage in less tax avoidance. Several studies highlight the positive relationship between corporate tax payments and measures of CSR (Hoi, Wu, and Zhang 2013; Lanis and Richardson 2013; 2015). Given that employee relations are an important component of CSR, it is possible that firms committed to CSR, and who avoid less income taxes, would also be less willing to avoid payroll taxes. While tax payments and CSR could have a negative relation if firms that engage in aggressive tax avoidance increase their CSR activities (Davis et al. 2016), this concern is mitigated since intentionally misclassifying employees denies wages, benefits, and protections, as entitled by law, and therefore not likely to be considered socially responsible.

While the argument above has merit, it is not without tension. Tax avoidance can be characterized as the attempt to minimize a tax liability within the provisions of the law and income taxes and payroll taxes are inherently different. It is likely that management assess the relative risks and rewards for different types of taxes individually. Following Hanlon and Heitzman (2010), tax avoidance can be considered as a continuum with legal and acceptable strategies on one end and illegal activities on the other. Employee classification is likely best considered as a grey area. While employee misclassification can be intentional, it can also be an unintentional error. As the economy evolves, the typical employee versus independent contractor test is becoming convoluted and confusing. Firms should reduce payroll taxes by misclassifying employees, whether 
deliberately intentional or within the grey area, if the non-tax costs associated with the misclassification do not exceed the benefit. It is important to note that the non-tax associated costs with employee misclassification are not trivial and these costs are now likely much higher given that workers have become more knowledgeable about their rights (Johnson 2010). Furthermore, if firms misclassify employees as contractors to save on payroll taxes, or other labor related costs, profits will increase which may lead to higher income taxes. Therefore, firms may substitute different types of tax payments that ultimately result in the highest after-tax income.

Taken together, if income tax avoidance is positively related to payroll tax avoidance, then payroll and income taxes act as compliments. On the contrary, if income tax avoidance is negatively related to payroll tax avoidance, then payroll and income taxes act as substitutes. There is also the possibility that income and payroll tax avoidance are unrelated and/or the incentives to misclassify employees are not tax motivated. This leads to my first hypothesis, stated in the null form.

Hypothesis 1: There is no association between a firm's income tax avoidance behavior and its payroll tax avoidance.

Irrespective of whether income tax avoidance is associated with the likelihood of payroll tax avoidance, it is possible that successful labor violation audits would be of interest to the IRS. The IRS has a strong administrative preference for workers to be classified as employees (Steingold 2017). As employees, the IRS collects all withheld income taxes from the employer. As independent contractors, the IRS must collect and analyze the income taxes for each misclassified employee. The IRS may consider that firms that avoid payroll taxes have a risk tolerance that may translate to other aggressive tax behavior. This view is consistent with 
Hypothesis 1. Given the risk, there are non-random reasons why a firm would choose to misclassify employees and engage in payroll tax avoidance. One such reason is capital market pressure which has also been shown to impact income tax avoidance. (Huseynov, Sardarli, and Zhang 2017; S. Chen et al. 2019). Another potential reason is equity-based incentive compensation which increases managerial risk-taking. Many studies have shown that incentive compensation is associated with increased levels of income tax avoidance (Armstrong, Blouin, and Larcker 2012; Rego and Wilson 2012; Halioui, Neifar, and Abdelaziz 2016). Importantly, while payroll and income tax avoidance may or may not be related, the incentives that encourage managers to engage in payroll tax avoidance may cause the IRS to believe that further scrutiny into other activities is warranted. Given the statute of limitations, if misclassification is deemed to be intentional, the IRS can reassess the misclassifying firm for unpaid payroll/other taxes plus interest and penalties for the previous 3 years.

Tax authority enforcement has been shown to impact tax behavior. Li, Pittman, and Wang (2019) use confidential Chinese tax audit data and find that after firms have been audited, they significantly increase their effective tax rates, reduce their book-tax differences, and reduce their income-decreasing discretionary accruals. While DeBacker et al. (2015) use confidential IRS audit data to show that corporations gradually increase their tax aggressiveness following an audit, they find that firms reduce their tax aggressiveness when the perceived audit probability increases again.

While prior research focuses on the effects of tax audits on future tax compliance, the data is often proprietary. Ex-ante, it is not clear who is audited by the IRS and the probability of being audited by a fiscal authority is not evenly distributed across time, firms, or jurisdictions (Kovermann and Velte 2019). Some prior studies have circumvented the proprietary data issue by 
relying on Transactional Records Access Clearinghouse (TRAC) data to calculate the probability of an IRS audit based on asset size. One such study is Hoopes, Mescall, and Pittman (2012) who find that higher tax enforcement by the tax authority reduces tax avoidance. Using the TRAC data, the audit probability is calculated as the number of corporate tax return audits completed divided by the number of corporate tax returns received by the IRS each year across eight nominal asset levels. This measure represents the ex-ante risk of an IRS audit rather than an actual audit. In a similar vein, successful DOL audits may increase the ex-ante risk of an IRS audit.

Conceptually, the threat of IRS scrutiny should reduce tax avoidance because it increases the probability of detection. This is consistent with Atwood et al. (2012) who find that firms avoid less taxes when tax enforcement is perceived to be stronger. Prior literature has shown that regulatory agencies other than the IRS may impact income tax avoidance. Kubick et al. (2016) find that firms receiving a tax-related SEC comment letter, relative to firms receiving a non-tax comment letter, decrease their tax avoidance behavior.

In September 2011, the IRS signed a Memorandum of Understanding (MOU) with the Department of Labor. As part of the agreement, the Department of Labor will provide Wage and Hour investigation data to the IRS if the Department of Labor believes it raises employment tax compliance related to misclassification. In the 5 years since the signing of the MOU, the IRS evaluated and classified more than 1,300 DOL referrals, with $39 \%$ selected for further examinations. Under the agreement, the agencies will work together and share information to reduce the misclassification of employees, to reduce the tax gap, and to improve compliance with federal labor laws. In that sense, while DOL investigations may not be indicative of a future IRS audit, firms may perceive increased potential scrutiny from tax/employment authorities on other aggressive tax positions and may adjust their behavior accordingly. 
On the contrary, while the US government has committed to cooperative enforcement efforts between the DOL, IRS, and individual state unemployment agencies, the collaboration between the agencies has also not been very effective. The Treasury Inspector General for Tax Administration found that DOL referrals were less productive than worker classification examinations by the IRS that originated from other sources (TIJTA 2018). For this reason, firms may not believe that WHD audits increase the risk of increased scrutiny from the IRS.

Taken together, this leads to the second hypothesis, stated in the null form.

Hypothesis 2: There is no change in firm income tax avoidance behavior following the discovery of payroll tax avoidance during a WHD DOL Audit. 


\section{Chapter 4 \\ Methodology}

In this chapter, I provide the proxy for my variables of interest (i.e., payroll and income tax avoidance). I also highlight the empirical models used to test my hypotheses and a discussion of the relevant control variables.

\subsection{Measure of Payroll Tax Avoidance}

As discussed in earlier chapters, payroll taxes are not directly observable or reported in publicly available financial statements. To further complicate the issue, firms may legitimately hire independent contractors. While a researcher could compare the number of FTEs relative to their competitors, the payroll tax on their income tax returns, or the number of 1099-Misc forms (i.e., the tax form provided to each independent contractor), it is unclear how any of these would best approximate payroll tax avoidance. It is important to note that in and of itself, the decision to hire an employee versus an independent contractor is not illegal. Firms can, and should, do whatever is best for their business, reputation, and shareholders. On the contrary, it is the misclassification of employees that is against the law because of employer responsibilities mandated through tax and labor legislation (i.e., FICA, FLSA).

To circumvent this issue, and to proxy for payroll tax avoidance through employee misclassification, I rely on the Department of Labor Wage and Hour Compliance Action Enforcement dataset. This dataset contains all concluded Wage and Hour Compliance audits that relate to US labor laws. The Wage and Hour Division (WHD) enforces federal minimum wage, overtime pay, recordkeeping, and child labor requirements of the Fair Labor Standards Act and other labor acts including the Migrant and Seasonal Agricultural Worker Protection Act, the Employee Polygraph Protection Act, the Family and Medical Leave Act, Davis-Bacon and Related 
Acts, the Service Contract Act, etc. WHD audits mainly relate to the Fair Labor Standards Act. By misclassifying employees as independent contractors, firms deny their misclassified employees the benefits and protections mandated by the FLSA. Given the above, my proxy for payroll tax avoidance, or employee misclassification, is the discovery of FLSA violations during a WHD audit.

A WHD investigation can include all employees and independent contractors for a threeyear period. This corresponds to the three-year statute of limitations for willful violations. Workers often file a complaint when filing for unemployment and realizing they are not entitled, or when they are injured and not entitled to disability. Therefore, the complaints are likely to be timely in nature. As a caveat, the findings start/end date provided in the publicly available WHD dataset do not equal the date for which the audit was initiated/closed. To mitigate this issue, a Freedom of Information Act request was submitted whereby I received the case start and end date. ${ }^{21}$ The average (median) duration for an audit is 243 (130) days.

The dataset contains the number of labor violations found for each labor law, back wage amount, number of employees' due back wages, and civil money penalties assessed for each concluded audit. The use of this dataset removes the ambiguity of arbitrarily assuming employee misclassification through abnormally low payroll taxes. Instead, the data accurately identifies instances of labor wage violations for a given firm. One issue with the data is that it only represents investigations. Consistent with other types of enforcement, not every company is investigated every year, or ever at all, and there are likely non-random reasons why a firm is selected for an

\footnotetext{
${ }^{21}$ A Freedom of Information Act (FOIA) request was made in April 2020. See https://www.dol.gov/foia/: Tracking Number - 891322. A final response was received Match 8, 2021.
} 
Audit. ${ }^{22}$ However, most relevant to this paper, is the fact that investigations can lead to either detected violations or no violations. Therefore, the data provides a clean measure as to whether labor law violations were identified for a given investigation.

Another limitation of the data is that most investigations are related to small private companies. ${ }^{23}$ Given the research question, I require public financial accounting data to determine if there is a relationship between income tax and payroll tax avoidance. While this significantly reduces the sample, it should not bias the results. I argued above that, on occasion, employee misclassification occurs because of ambiguous criteria in determining employee status at the Department of Labor, IRS, and State Levels (Donahue, Lamare, and Kotler 2007). This ambiguity (and potential confusion) should be of greatest importance to companies that lack sophisticated tax/human resource departments. Therefore, it is likely that large public companies are more often intentionally, and not mistakenly, misclassifying employees. Additionally, given the trade-off literature, the associated non-tax costs from intentionally misclassifying employees are likely higher for public firms relative to small private firms.

\subsection{Measure of Income Tax Avoidance}

While many proxies exist for income tax avoidance, I employ Cash ETR defined as the ratio of cash taxes paid divided by pre-tax income. I choose this proxy because it represents the effects of both permanent and temporary tax avoidance strategies, is inclusive of both conservative and aggressive tax avoidance activities, and is not biased by changes in accounting accruals

\footnotetext{
22 To control for this sample selection issue, I employ a Heckman Selection Model (Heckman 1979). See Research Design.

23 Paying employees in cash is a common method of evading income and employment taxes used in small businesses. Therefore, the large incidence of private firms is not surprising.
} 
(Dyreng, Hanlon, and Maydew 2008). To employ this proxy, I require that firms must have nonmissing, and positive pre-tax income, and I remove observations where CashETR is above $100 \%$ or below $0 \%$ of pre-tax income. ${ }^{24}$

\subsection{Empirical Model}

In this subsection, I highlight the empirical models and relevant control variables used to test the hypotheses.

\subsubsection{Likelihood of a Successful Employee Misclassification Audit}

Hypothesis one posits an association between a firm's income tax avoidance behavior and its payroll tax avoidance through employee misclassification. As discussed in the literature review, very little is known about the determinants of payroll tax avoidance. Anecdotally, "misclassified workers can be found in almost every sector of the economy, working for small companies to publicly traded multinational corporations" (Carré 2015). Given that misclassification of employees denies employees their benefits and protections under the Fair Labor Standards Act (FLSA), I define a successful employee misclassification audit if the number of total FLSA case violations is greater than zero. For robustness and falsification tests, I also consider all WHD case labor violations. The logic for the falsification test is that labor violations not related to the FLSA statute would not be motivated by payroll tax savings.

Ex-ante, it is unclear whether income tax avoidance should predict payroll tax avoidance, or whether payroll tax avoidance should predict income tax avoidance. While I motivate the test through companies avoiding certain types of taxes being more inclined to avoid other types of

\footnotetext{
${ }^{24}$ Results remain consistent if negative CashETR outliers are reset to 0 and if positive CashETR outliers are reset to 1 .
} 
taxes, I justify income tax avoidance as the dependent variable because, at least in certain instances, income tax avoidance is less risky. Conversely, especially for the large publicly traded firms included in my sample, employee misclassification is illegal (or at least very aggressive). Gallemore, Maydew, and Thornock (2014) argue that "when the managers decide to engage in tax avoidance, they weigh the expected benefits of tax avoidance against the expected costs and will not engage in tax avoidance unless the net benefits are positive in an expected value sense." This implies that firms should take relatively low-risk (i.e., legal) tax avoidance strategies and then as these opportunities are utilized, take progressively more aggressive positions until the expected value is zero. For this reason, legal income tax avoidance, at least conceptually, should precede illegal (or questionable) payroll tax avoidance through employee misclassification.

Given that I am interested in examining the determinants of payroll tax avoidance through employee misclassification, I estimate the determinants on the subsample of firms that have had WHD audits. However, given that the audit itself is likely not random, without controlling for the sample selection issue, the results may be biased and unrepresentative (Maddala 1991). To control for the potential sample selection bias, I employ a Heckman two-step correction procedure (Heckman 1979). In the first stage, I estimate a probit model for having a WHD audit. In the second stage, I correct for the selection bias by including the fitted values from the first stage selection equation (i.e., the Inverse Mills ratio). This research design models the chance of a successful misclassification audit based on individual firm characteristics, and importantly, the measure of income tax avoidance while also addressing the endogeneity concern related to the selection bias. 
The model is specified as:

\section{Stage 1:}

$$
\begin{aligned}
& \text { (1) } \operatorname{Pr}(\text { WHD Audit })=\beta_{0}+\sum \beta_{k} \text { FirmTaxAvoidance Controls }_{i, t} \\
& +\sum \beta_{k} \text { Firm EmployeeControls } \text { Cit, }+ \text { Priority Industry }+ \text { HPState }+\epsilon_{t}
\end{aligned}
$$

\section{Stage 2:}

(2) $\operatorname{Pr}($ FLSA Violations $)=\beta_{0}+\boldsymbol{\beta}_{\mathbf{1}}$ CashETR $+\sum \beta_{k}$ FirmTaxAvoidance Controls Cit,

$$
+\sum \beta_{k} \text { Firm EmployeeControls } \text { Eit, }+\lambda+\epsilon_{t}
$$

The coefficient of interest for Hypothesis one is $\beta 1$ in the second stage of the Heckman two-step model. A negative coefficient would be consistent with WHD audits being more likely to discover FLSA violations (i.e., employee misclassification) for firms with lower cash taxes paid (i.e., higher income tax avoidance) after controlling for the potential selection bias of being audited by the WHD. A positive coefficient would be consistent with WHD audits being more likely to discover FLSA violations (i.e., employee misclassification) for firms with higher cash taxes paid (i.e., lower income tax avoidance) after controlling for the potential selection bias of being audited by the WHD.

Since the determinants of payroll tax avoidance are not well established, I control for the traditional firm-level variables that impact income tax avoidance, and the direct benefits and nontax costs related to payroll tax avoidance. The direct benefits and non-tax costs should encourage or discourage firms from misclassifying employees as independent contractors. 
I justify the inclusion of typical income tax avoidance controls because firm characteristics that predict corporate income tax avoidance likely capture many of the same opportunities and incentives to predict other types of tax avoidance. I control for firm size (size) since larger firms have more resources available to engage in tax avoidance, firm profitability $(R O A)$ because more profitable firms have a greater incentive to reduce taxes, leverage (leverage) because of the tax deductibility of interest, income from foreign operations (ForeignIncome) because of the opportunity to shift taxable income to lower-tax jurisdictions, and capital intensity (CapIntensity) because capital-intensive firms have cash tax benefits related to accelerated depreciation. I also control for income related to the equity method of accounting (EquityIncome), intangibles (Intangibles), and research and development activities $(R D)$ to control for the differences in the financial and tax accounting treatment of equity investments, intangibles, and research and development activities, respectfully. Lastly, I control for advertising expenditures ( $A D V)$ to proxy for political costs and reputation, the number of pre-tax losses that a firm experienced over the previous four years (LossIntensity) to control for the opportunity to utilize loss carry forwards, and whether the firm had negative profitability (LossFirm) since these firms will have a disincentive to engage in tax avoidance.

If each firm considers the direct benefits of payroll tax avoidance against its associated non-tax costs, I need to control for the benefits and costs related to misclassification. Therefore, I include variables that either increase the benefit of misclassification or increase the non-tax costs related to misclassification/detection. I control for whether the firm is audited by a Big 4 auditor (Big4) because the auditing literature suggests that the audit quality of Big 4 auditors is higher relative to non-Big 4 auditors since larger accounting firms provide higher quality services to protect their reputations (Simunic 1980). Additionally, I control for employee bargaining power. 
Firms who have a higher intensity of employees (Employees), are unionized (Union), offer a pension (Pension), are headquartered in a state with a higher minimum wage then the federal level (MinWageGreaterthenFederal), or are headquartered in a state with a higher median income then the federal level (MedIncomeGreaterthenFederal) have a stronger incentive to misclassify and save on employee related costs.

For proper identification, the Heckman model requires a valid exclusion restriction in the selection model that affects selection but not the outcome (Wolfolds and Siegel 2019). To provide context, I need an exclusion restriction that either increases or decreases the likelihood of being audited by the WHD without affecting the chance of violations being detected. I propose two such restrictions. First, in his report to the Wage and Hour Division, Weil (2010), identifies a subset of industries that should be the focus of WHD attention because such industries have a large concentration of vulnerable workers, workers are unlikely to step forward, and the WHD is likely to change employer behavior. Given that the WHD requested this report, and David Weil became the administrator of the WHD under President Obama in 2014, these identified targeted industries are more likely to be audited regardless of firm characteristics. For this reason, one exclusion variable is whether the firm operates in a Priority Industry (PriorityIndustry). Second, in 2014, the DOL provided Worker Misclassification Grants to high performing individual states to improve their own worker misclassification detection and enforcement initiatives. Given that the basis of these awards was performance, it is likely that these states are better at deterring and/or identifying misclassification relative to others and are thus less likely to require the DOL to combat misclassification. As such, firms that operate in these states are less likely to be audited by the WHD regardless of firm characteristics (HPState). In untabulated results, the results remain 
consistent when only the Priority Industry indicator or the High Performing State indicator are included as the exclusion restriction.

I include industry and year fixed effects to control for industry-level differences in tax planning. Detailed variable definitions are included in Appendix 1.

\subsubsection{Change in Firm Behavior Post DOL Investigation}

Hypothesis two tests whether the income tax avoidance behavior of a firm changes following the detection of employee misclassification during a WHD audit. To test hypothesis two, I employ a staggered DiD research design whereby I compare the change in behavior for firms that had employee misclassification detected versus firms that did not have any labor violations detected. $^{25}$

The model is specified as:

(3) Tax Avoidance $=\beta_{0}+\boldsymbol{\beta}_{1}$ Treat $*$ Post $+\beta_{2}$ Treat $+\beta_{3}$ Post

$$
+\sum \beta_{k} \text { Firm Controls }_{i, t}+\text { Year FE }+ \text { Industy FE }+\epsilon_{t}
$$

Treat equals 1 for public firms that have been subjected to a successful WHD audit (i.e., an audit that discovers FLSA violations) in either the year or two years pre/post a given WHD audit, and 0 otherwise. I choose this treatment effect because some firms are subjected to multiple WHD audits. Therefore, the treatment effect of one audit would overlap the treatment effect of another audit. Post equals 1 in the two subsequent years of a WHD audit, regardless of whether

\footnotetext{
25 I include firms with WHD (i.e., other labor violations) but not FLSA violations as a control group in robustness tests.
} 
the audit was successful. The logic for two years is consistent with the fact that the FLSA contains a two-year statute of limitations (three-years for willful violations). I also include industry and year fixed effects to control for industry-level differences in tax planning.

For this test, I rely exclusively on the successful versus unsuccessful WHD audits because it is unclear if firms not subjected to an audit are misclassifying employees but have yet to be caught. ${ }^{26}$ I include a similar set of controls and fixed effects as Hypothesis 1. Detailed variable definitions are presented in Appendix 1.

${ }^{26}$ I conduct a test with propensity score-matched sample for robustness. 


\section{Chapter 5 \\ Empirical Analyses}

In this chapter, I provide a description of the sample and data source. I then discuss my main results and the robustness tests used to answer my research question regarding the relationship between payroll and income tax avoidance.

\subsection{Sample Selection}

Table 1 Panel A presents the sample-selection process. I begin with all publicly available WHD audits. ${ }^{27}$ While there are over 300,000 unique investigations, I restrict the sample to publicly traded (i.e., Compustat) firms. Most of the sample attrition results from WHD audits primarily being conducted on private firms. This is consistent with the notion that either private firms lack the appropriate accounting or HR department to aid in compliance, and/or these firms have a different benefit and risk trade-off given the lower ex-ante threat of detection/enforcement or other non-tax costs. To match the firms in the WHD Sample to Compustat, I rely on the EIN number provided from my FOIA request rather than a matching procedure on the Company Legal Name. This results in 4,949 unique investigations. While the dataset contains all investigations from FY 2005, it includes findings from as early as 1984 . I constrain the investigation findings data to begin in 2004 because this is the first year provided in the FOIA request. I also constrain the data to end in 2018 to have a two-year post period for testing Hypothesis 2. Some firms are audited more than once in a calendar year. Since my tests are conducted at the firm-year level, I sum the total FLSA violations for a given firm each year to get the net result of all the WHD Audits and remove any

\footnotetext{
${ }^{27}$ Wage and Hour Compliance Action Data can be found at: https://enforcedata.dol.gov/views/data_catalogs.php.
} 
duplicates. Given that I require WHD Audits to detect FLSA violations, regardless of which specific audit discovers FLSA violations, FLSA violations would exist in a given year.

In total, there are 1,949 unique firm-year audit observations. 723 firm-year audits have zero labor violations (37.10\%), and 1,226 firm-year audits have non-zero labor law violations (62.90\%). While not perfectly balanced, it is encouraging that the number of successful audits is not substantially different from the number of unsuccessful audits.

Table 2 Panel A and B provide the observations over the sample period and further separate the WHD Audits into audits with FLSA violations. Of the 1,226 firm-year audits with non-zero labor law violations, 749 (61.09\%) have FLSA labor violations. Given that FLSA violations are my proxy for misclassification, 749 of the 1,949 (38.43\%) audits detect misclassification. Overall, the number of observations is well distributed by year. Figures 1 and 2 provide the time trend.

Table 2 Panel C and D provide the observations across industries. Consistent with above, the number of observations is well distributed across industries when considering all WHD violations or when only considering FLSA violations. ${ }^{28}$ Figures 3 and 4 graphically represent the industry distribution.

\subsection{Descriptive Statistics}

Table 3 provides descriptive statistics for the income tax avoidance measure and the control variables used in this study. All continuous variables are winsorized at the $1 \%$ and $99 \%$ levels to reduce the effect of outliers on the analyses. Panel A provides the descriptive statistics for all WHD audits, Panel B provides the descriptive statistics for WHD audits with FLSA Violations, Panel C

\footnotetext{
${ }^{28}$ My results are robust to the exclusion of firms in the financial services industry.
} 
provides the descriptive statistics for WHD audits with positive violations but without FLSA violations, and Panel D provides the descriptive statistics for WHD audits without any violations.

Panel E compares the differences in means between the WHD audits with FLSA violations and the WHD audits without any violations, Panel F compares the differences in means between the WHD audits with labor violations and the WHD audits without any violations, and Panel G compares the differences in means between the WHD audits with non FLSA labor violations and the WHD audits with FLSA violations. For most of the variables the two groups are not significantly different. This indicates that the discovery of FLSA violations are not concentrated on fundamentally different firms. However, to alleviate concerns, I conduct a test with a propensity score-matched sample for robustness in section 5.4.3.

\subsection{Multivariate Tests}

In this subsection, I provide a discussion of my main findings.

\subsubsection{Likelihood of a Successful Employee Misclassification Audit}

Table 4 presents the first stage result for modeling the likelihood of being audited by the WHD. The first column considers all observations while the second column removes observations that are either missing the data needed to calculate CashETR or have a CashETR calculated below 0 or above 1. Many of the coefficients are in the predicted direction, although not all are significant at traditional levels. The controls for employee bargaining power are almost all highly significant. Firms are more likely to be audited if they have a higher number of employees vs. sales ratio, are unionized, offer a pension, or are located in a state with a higher minimum wage than the federal level. Furthermore, the exclusion restrictions (i.e., PriorityIndustry and HPState) are highly significant. Consistent with expectations, the likelihood of being audited is strongly, positively 
related to being in a priority industry as identified by Weil (2010). Additionally, being headquartered in a high performing state is negatively related to the likelihood of being audited. This is consistent with these states being less reliant on the federal DOL to detect misclassification because of the strength of their own employer audit programs. While not directly related to my research question, an indirect contribution of this study is the documentation of the determinants of DOL labor audits.

Table 5 presents the second stage results for modeling the likelihood of being found to be a labor violator conditional on controlling for the determinants of being selected for a WHD audit. While columns 1 and 2 consider all WHD labor violations, columns 3 and 4 only consider FLSA violations. Furthermore, Columns 1 and 3 do not include CashETR. While I am most interested in studying whether income tax avoidance is related to payroll tax avoidance, given the scarcity related to payroll tax avoidance, it is also relevant to document whether other firm attributes are positive predictors of misclassification.

I observe a significantly positive coefficient on Cash ETR only for FLSA violations. As can be seen in Column 2, while positive, CashETR is not statistically significant when considering all labor violations. This is of note for two reasons. First, this test offers validation to my measure of payroll tax avoidance given that misclassification is a violation of FLSA laws and not all WHD violations. Second, the positive coefficient on CashETR in Column 4 suggests that WHD audits are more likely to discover FLSA violations for firms with higher cash taxes paid. Put simply, firms with higher CashETR are more likely to avoid payroll taxes through employee misclassification. One potential explanation is that these firms do not have the ability to avoid income taxes and look for other approaches to reduce their total tax expense. 
Regarding economic significance, CashETR has a positive coefficient of 0.289 (p-value, 0.003). This implies that if CashETR decreases by 1 percentage point, holding everything else constant, the firm is $0.335 \%$ less likely to have FLSA labor violations (i.e., employee misclassification) detected by a WHD audit. ${ }^{29}$ In my sample, the standard deviation of CashETR is $16.4 \%$. Therefore, a one-standard deviation increase in CashETR reduces the likelihood of discovering FLSA labor violations by approximately $5.5 \%$.

\subsubsection{Change in Firm Tax Avoidance Behavior Post DOL Investigation}

Table 6 presents the results for Hypothesis 2 and is related to the change in CashETR following the discovery of FLSA labor violations during a WHD audit. Treated firms represent those firms that have had labor violations detected in either the year, or two years before or after the WHD audit. Control Firms represent those firms that have been subjected to unsuccessful WHD audits in either the year, or two years before or after a WHD audit. This specification was implemented because it is difficult to decipher which specific audit-year is driving the result if a firm is subject to multiple WHD audits year after year. Additionally, the CashETR reaction may not be immediate.

The DiD coefficient is positive across all specifications when considering all WHD violations and when only considering FLSA violations. However, the coefficient is only significant with FLSA violations as the treatment group. This suggests that following the discovery of FLSA labor violations, firms increase their CashETR. This result signals that firms adjust their income tax planning down. Following the discovery of FLSA violations, firms reduce their CashETR by 2.1 to 2.3 percent. I conjecture that firms decrease their income tax avoidance to reflect the threat

$29 e^{.289}-1=0.335 \%$ 
of increased IRS scrutiny and that firms update the cost-benefit trade-off of other aggressive tax positions. In untabulated tests, the results remain consistent when I add the ex-ante threat of audit enforcement. Consistent with prior literature (ex., Hoopes, Mescall, and Pittman 2012) the audit probability for a firm-year is calculated as the number of corporate audits completed in the same asset class as the firm divided by the total number of corporate tax returns filed in that asset class in the prior year.

\subsection{Robustness Tests}

\subsubsection{Validation of Misclassification Proxy}

Tables 7 and 8 provide additional support that FLSA violations are detecting employee misclassification. Following a similar difference-in-difference research design to Equation (3), in Table 7, I examine whether FLSA violations result in changes to the employee intensity of a firm (\# of employees/sales). Employee misclassification implies that true employees are being mislabeled as independent contractors. For that reason, employee intensity will be artificially lower than for firms properly recording employees. When considering FLSA violations, the DiD coefficient is positive and statistically significant with and without industry fixed effects. However, when considering all WHD violations, the DiD coefficient is positive but not significant at traditional levels. The positive and significant coefficient related to FLSA violations provides assurance that the proxy for payroll tax avoidance is indeed related to misclassification. It is difficult to corroborate why employee intensity would increase for reasons other than employees being properly recorded after being underreported and mislabeled as independent contractors.

In Table 8, again with a similar difference-in-difference research design, I test whether FLSA violations result in cost classification differences on the Income Statement, or changes in 
profitability. I do this for two reasons. First, it is likely harder to justify independent contractor status if the work being performed is directly related to sales. I support this conjecture because when the IRS or DOL assess employee classification, they consider the extent to which the services performed are a key aspect of the regular business of the company. Therefore, given that Cost of Goods Sold (COGS) represent the direct costs incurred in the production of goods or services, firms may want to avoid classifying the labor costs of misclassified employees as COGS and instead classify the costs as Selling, General, and Admin (SG\&A) expenses. Second, there may be non-tax reasons for misclassifying employees as independent contractors that are more important than payroll taxes. Firms may misclassify employees to reduce labor costs with taxes being a secondary, or non-important, consideration.

In Table 8, Panel A, I present the test for the impact of WHD audits on the COGS percentage of sales. Following the discovery of FLSA violations and all labor violations, relative to the control group, the $\mathrm{DiD}$ coefficient is positive, although not significant at traditional levels. Conversely, in Table 8, Panel B, I present results following a similar approach to test for changes in Selling, General and Administrative Expenses. Again, while the DiD coefficient is negative, it is not significant at traditional levels. Taken together, these results provide some, albeit not significant, comfort that firms increase COGS and decrease SGA following the detection of labor violations. In Table 8, Panel C, I present results for the impact of WHD audits on firm ROA. Following the discovery of FLSA violations and all labor violations, relative to the control group, firm profitability, does not materially change. This result provides assurance that the motivation to misclassify employees relates to taxes and not reducing other non-tax costs. 


\subsubsection{Sample Partitions}

Each firm has a unique optimal level of tax avoidance that balances the costs of different tax planning techniques with the benefits (Kim et al. 2019). In that sense, each firm has a unique portfolio of tax planning tools available to employ. In Table 9, I partition sample firms into groups that are more likely to engage in higher rates of tax avoidance to see if the effect in Table 6 differs across groups. Following Guenther, Wilson, and Wu (2019), I partition my sample into firms that are considered to be multinational and domestic. For this partition, the DiD coefficient is only significant for domestic firms. This suggests that firms with more tax planning opportunities do not exhibit the same increase in their taxes paid following the detection of employee misclassification.

\subsubsection{PSM-Matched Sample}

To address potential concerns that firms in the treatment group and the control group might not be comparable, I re-estimate the difference-in-difference model using industry-year matched pairs of treatment and control firms. To do this analysis, I use a logit model to estimate a propensity score of being audited based on the same controls employed in the Heckman determinants model from Table 4. To match audited firms with firms in the control group, I perform 1:1 matching within a .25 caliper width. Intuitively, I create matched pairs by identifying a firm in the control group that is similar to a treated firm but who has not been audited. The results using this propensity score matched sample are presented in Table 10, Panel A. Consistent with the results from Table 6, only FLSA violations have a positive and significant coefficient on the interaction term. The coefficient of interest (0.023) is quantitatively similar to the results from Table 6 . This test provides some assurance that the WHD audit itself is not driving the results. Rather, it is the 
discovery of FLSA violations during the audit, or my proxy for employee misclassification, that impacts CashETR.

\subsubsection{Alternative Control Group}

In my main specification from Table 6, the control group are firms subjected to an audit but for which no labor violations were found. As a robustness check, I test whether the results remain consistent when I consider all audited firms without FLSA violations as the control group.

The results are presented in Table 10, Panel B. The DiD coefficient remains positive with and without Industry and Year fixed effects. The coefficient of interest $(2.2 \%-2.5 \%)$ is quantitatively similar to the results from Table 6.

\subsubsection{Alternative Treatment Group}

Under the FLSA, there are two types of employee misclassification. While some employers misclassify employees as independent contractors, other employers misclassify employees as being exempt from overtime. In general, to be considered an exempt employee, the employee must be paid a salary (i.e., not hourly) and must perform executive, administrative, or professional duties. Importantly, the motivation for misclassifying employees as independent contractors relative to being exempt vs. non-exempt are likely different. Employers often intentionally misclassify their employees as exempt to avoid paying overtime wages. On the contrary, the primary benefit of misclassifying employees as independent contractors is to avoid FICA. Given that I am interested in studying payroll tax avoidance, I am most interested in the FLSA violations that specifically relate to employee misclassification. While the dataset does not differentiate the two types of FLSA violations, it does provide the total back wages related to FLSA minimum wage violations and the total back wages related to FLSA overtime violations. Given that an employee must be paid a salary to be exempt from overtime, minimum wage violations are more 
likely indicative of employee misclassification. For this reason, I consider any back wage related to minimum wage being indicative of independent contractor misclassification rather than an exempt misclassification.

Table 10, Panel C presents the results whereby treated firms are those firms that have had back wages related to minimum wage labor violations detected in either the year, or two years before or after the WHD audit. In columns 1 and 2, control firms represent those firms that have been subjected to unsuccessful WHD audits in either the year, or two years before or after a WHD audit. In columns 3 and 4, control firms represent those firms that have been subjected to a WHD audit in either the year, or two years before or after a WHD audit and have had either zero labor violations or zero assessed back wages for minimum wage violations. In all specifications, the results are positive and statistically significant. The results are also stronger and more positive than in the main specification from Table 6. This provides comfort that the change in income tax avoidance is concentrated for firms that avoid payroll taxes through misclassifying employees as independent contractors rather than as employees being exempt from overtime. This also provides assurance that the motivation for the misclassification is related to payroll tax savings rather than other labor cost savings. 


\section{Chapter 6 \\ Conclusion}

This paper empirically identifies whether firms that avoid income taxes also avoid payroll taxes. Given the recent rise of the Gig Economy, there has been an increasing trend for employers to classify their employees as independent contractors. While this classification may be legitimate, some firms intentionally misclassify their employees to reduce costs. By misclassifying an employee as an independent contractor, a firm can avoid their share of the FICA contribution which, for the typical firm, represents a large cost.

To answer the research question, I first establish that income tax avoidance is negatively related to the likelihood of successfully discovering FLSA violations during a WHD audit. I then establish that firms increase their income taxes paid following the detection of FLSA violations during a WHD Audit. Taken together, these results suggest that firms that avoid income taxes also avoid payroll taxes.

The results are important for a variety of reasons. First, little is known about the determinants of payroll tax avoidance or the determinants of being audited by the DOL for labour violations. Second, by showing that firms that avoid income taxes also avoid payroll taxes, I provide evidence consistent with the complementarity of avoiding different types of taxes. Third, given a reduction in income tax avoidance following the discovery of labor violations, governments may be able to reduce the tax gap in ways other than through traditional IRS tax enforcement activities. Different types of enforcement, including WHD audits, may cause firms to adjust their tax avoidance trade-off and increase taxes paid. 


\section{References}

Allingham, Michael G., and Agnar Sandmo. 1972. "Income Tax Evasion: A Theoretical Analysis." Journal of Public Economics 1 (3-4): 323-38.

Armstrong, Christopher S., Jennifer L. Blouin, and David F. Larcker. 2012. "The Incentives for Tax Planning." Journal of Accounting and Economics 53 (1-2): 391-411. https://doi.org/10.1016/j.jacceco.2011.04.001.

Bughin, Jacques, James Manyika, Susan Lund, Kelsey Robinson, Jan Mischke, and Deepa Mahajan. 2016. "Independent Work: Choice, Necessity, and the Gig Economy." McKinsey Global Institute, no. October. https://www.mckinsey.com/ /media/McKinsey/Featured Insights/Employment and Growth/Independent work Choice necessity and the gig economy/Independent-Work-Choice-necessity-and-the-gig-economy-Full-report.ashx.

Carré, Françoise. 2015. “(In)Dependent Contractor Misclassification.” Economic Policy Institute. https://www.epi.org/publication/independent-contractor-misclassification/.

Chau, Terence, and Raquel Artecona. 2017. "Labour Issues in the Digital Economy." United Nations: ECLAC, no. July: 27. https://repositorio.cepal.org/bitstream/handle/11362/42046/1/S1700563_en.pdf.

Chen, Author Kong-pin, and C Y Cyrus Chu. 2005. "Internal Control versus External Manipulation: A Model of Corporate Income Tax Evasion.” The RAND Journal of Economics 36 (1): 151-64.

Chen, Shuping, Ying Huang, Ningzhong Li, and T. Shevlin. 2019. "How Does Quasi-Indexer Ownership Affect Corporate Tax Planning?" Journal of Accounting and Economics 67 (23): 278-96. https://doi.org/10.1016/j.jacceco.2018.01.001.

Christensen, Kevin, Robert Cline, and Tom Neubig. 2001. 'Total Corporate Taxation: 'Hidden,' above-the-Line, Non-Income Taxes.” National Tax Journal 54 (3): 495-506. https://doi.org/10.17310/ntj.2001.3.05.

Collins, Brett, Andrew Garin, Emilie Jackson, Dmitri Koustas, and Mark Payne. 2019. "Is Gig Work Replacing Traditional Employment? Evidence from Two Decades of Tax Returns *." https://www.irs.gov/pub/irs-soi/19rpgigworkreplacingtraditionalemployment.pdf.

Cruz, Marvin. 2019. "Taxing Payroll: A Barrier to Business Growth and Competitiveness." Canadian Federation of Independent Business.

Davis, Angela K., David A. Guenther, Linda K. Krull, and Brian M. Williams. 2016. "Do Socially Responsible Firms Pay More Taxes?” Accounting Review 91 (1): 47-68. https://doi.org/10.2308/accr-51224.

DeBacker, Jason, Bradley T. Heim, Anh Tran, and Alexander Yuskavage. 2015. "Legal Enforcement and Corporate Behavior: An Analysis of Tax Aggressiveness after an Audit." Journal of Law and Economics 58 (2): 291-324. https://doi.org/10.1086/684037. 
Donahue, Linda H, James Ryan Lamare, and Fred B Kotler. 2007. "The Cost of Worker Misclassification In New York State." Cornell University, School of Industrial and Labor Relations. Ithaca, NY. http://digitalcommons.irl.cornell.edu/reports/9.

Drake, M, R Hess, J Wilde, and B Williams. 2018. "The Relevance and Pricing of Non-Income Tax Relief." Working Paper. https://www.ntanet.org/wpcontent/uploads/2019/03/Session1253_Paper1895_FullPaper_1.pdf.

Dyreng, Scott D., Michelle Hanlon, and Edward L. Maydew. 2008. "Long-Run Corporate Tax Avoidance." Accounting Review 83 (1): 61-82. https://doi.org/10.2308/accr.2008.83.1.61.

Dyreng, Scott D., and Bradley P. Lindsey. 2009. "Using Financial Accounting Data to Examine the Effect of Foreign Operations Located in Tax Havens and Other Countries on U.S. Multinational Firms' Tax Rates." Journal of Accounting Research 47 (5): 1283-1316. https://doi.org/10.1111/j.1475-679X.2009.00346.x.

Dyreng, Scott, and Edward L. Maydew. 2018. "Virtual Issue on Tax Research." Journal of Accounting Research, no. 18: 4. https://doi.org/10.2139/ssrn.3068168.

Engel, Ellen, Merle Erickson, Edward Maydew, Ellen Engel, Merle Erickson, and Edward Maydewt. 1999. "Debt-Equity Hybrid Securities University of Chicago Stable" 37 (2): 24974.

Erickson, Merle M., Michelle L. Hanlon, Edward L. Maydew, and Terrence J. Shevlin. 2020. Taxes \& Business Strategy. 6th ed. Westmont, IL: Cambridge Business Publishers.

Gallemore, John, Edward L. Maydew, and Jacob R. Thornock. 2014. "The Reputational Costs of Tax Avoidance." Contemporary Accounting Research 31 (4): 1103-33. https://doi.org/10.1111/1911-3846.12055.

Guenther, David A, Ryan J Wilson, and Kaishu Wu. 2019. “Tax Uncertainty and Incremental Tax Avoidance" 94 (2): 229-47. https://doi.org/10.2308/accr-52194.

Gupta, Sanjay, and Lillian F. Mills. 2002. "Corporate Multistate Tax Planning: Benefits of Multiple Jurisdictions." Journal of Accounting and Economics 33 (1): 117-39. https://doi.org/10.1016/S0165-4101(01)00045-3.

Halioui, Khamoussi, Souhir Neifar, and Fouad Ben Abdelaziz. 2016. "Corporate Governance, CEO Compensation and Tax Aggressiveness: Evidence from American Firms Listed on the NASDAQ 100." Review of Accounting and Finance 15 (4): 445-62. https://doi.org/10.1108/RAF-01-2015-0018.

Hanlon, Michelle, and Shane Heitzman. 2010. “A Review of Tax Research.” Journal of Accounting and Economics 50 (2-3): 127-78. https://doi.org/10.1016/j.jacceco.2010.09.002.

Hoi, Chun Keung, Qiang Wu, and Hao Zhang. 2013. "Is Corporate Social Responsibility (CSR) Associated with Tax Avoidance? Evidence from Irresponsible CSR Activities.” Accounting 
Review 88 (6): 2025-59. https://doi.org/10.2308/accr-50544.

Hoopes, Jeffrey L., Devan Mescall, and Jeffrey A. Pittman. 2012. "Do IRS Audits Deter

Corporate Tax Avoidance?" Accounting Review 87 (5): 1603-39.

https://doi.org/10.2308/accr-50187.

Huseynov, Fariz, Sabuhi Sardarli, and Wei Zhang. 2017. "Does Index Addition Affect Corporate Tax Avoidance?" Journal of Corporate Finance 43: 241-59. https://doi.org/10.1016/j.jcorpfin.2017.01.008.

Internal Revenue Service. 2019. "2018 Databook."

—. 2020. Circular E, Employer's Tax Guide. Vol. 941.

IRS. 2020. "Publication 15-A: Employer's Supplemental Tax Guide."

James J. Heckman. 1979. "Sample Selection Bias as a Specification Error." Econometrica 47 (1): $153-61$.

Johnson, Sarah. 2010. "Cracking Down on Independent Contractors." CFO Magazine, March 2010. https://www.cfo.com/accounting-tax/2010/03/cracking-down-on-independentcontractors/.

Kim, Jaewoo, Sean T. McGuire, Steven Savoy, Ryan Wilson, and Judson Caskey. 2019. "How Quickly Do Firms Adjust to Optimal Levels of Tax Avoidance?" Contemporary Accounting Research 36 (3): 1824-60. https://doi.org/10.1111/1911-3846.12481.

Koustas, Dmitri K. 2019. "What Do Big Data Tell Us about Why People Take Gig Economy Jobs?" AEA Papers and Proceedings 109: 367-71. https://doi.org/10.1257/pandp.20191041.

Kovermann, Jost, and Patrick Velte. 2019. "The Impact of Corporate Governance on Corporate Tax Avoidance-A Literature Review." Journal of International Accounting, Auditing and Taxation 36. https://doi.org/10.1016/j.intaccaudtax.2019.100270.

Kubick, Thomas R., Daniel P. Lynch, Michael A. Mayberry, and Thomas C. Omer. 2016. "The Effects of Regulatory Scrutiny on Tax Avoidance: An Examination of SEC Comment Letters." Accounting Review 91 (6): 1751-80. https://doi.org/10.2308/accr-51433.

Lanis, Roman, and Grant Richardson. 2013. "Corporate Social Responsibility and Tax Aggressiveness: A Test of Legitimacy Theory." Accounting, Auditing and Accountability Journal 26 (1): 75-100. https://doi.org/10.1108/09513571311285621.

_ 2015. "Is Corporate Social Responsibility Performance Associated with Tax Avoidance?" Journal of Business Ethics 127 (2): 439-57. https://doi.org/10.1007/s10551014-2052-8.

Li, Wanfu, Jeffrey A. Pittman, and Zi Tian Wang. 2019. "The Determinants and Consequences of Tax Audits: Some Evidence from China." Journal of the American Taxation Association 
41 (1): 91-122. https://doi.org/10.2308/atax-52136.

Loten, Angus, and Emily Maltby. 2013. "Payroll Audits Put Small Employers on Edge.” Wall Street Journal, March 13, 2013. https://www.wsj.com/articles/SB10001424127887324392804578358473085106876.

Maddala, G. S. 1991. "A Perspective on the Use of Limited-Dependent and Qualitative Variables Models in Accounting Research.” The Accounting Review 66 (4): 788-807.

Messina, Frank, Ely Bruce P., Polack Lisa-Ann, and Marena Messina. 2019. "Employee Versus Independent Contractor: The IRS and Department of Labor's Focus on Worker Classification." The CPA Journal. https://www.cpajournal.com/2019/02/11/employeeversus-independent-contractor/.

Mulcahy, Diane. 2019. "How Can We Stop Companies From Misclassifying Employees As Independent Contractors?" Forbes, June 25, 2019. https://www.forbes.com/sites/dianemulcahy/2019/06/25/how-can-we-stop-companies-frommisclassifying-employees-as-independent-contractors/\#4dae62f2544c.

National Conference of State Legislatures. 2014. "Employee Misclassification Resources.” 2014. https://www.ncsl.org/research/labor-and-employment/employee-misclassificationresources.aspx\%0A.

Nessa, Michelle, Casey M. Schwab, Bridget Stomberg, and Erin M. Towery. 2020. "How Do IRS Resources Affect the Corporate Audit Process?” Accounting Review 95 (2): 311-38. https://doi.org/10.2308/accr-52520.

Parrish, Steve. 2013. "Should I Be An Employee Or An Independent Contractor?” Forbes, December 16, 2013. https://www.forbes.com/sites/steveparrish/2013/12/16/should-i-be-anemployee-or-an-independent-contractor/\#4dde93f6138c.

Rego, Sonja Olhoft, and Ryan Wilson. 2012. "Equity Risk Incentives and Corporate Tax Aggressiveness.” Journal of Accounting Research 50 (3): 775-810. https://doi.org/10.1111/j.1475-679X.2012.00438.x.

Robinson, Leslie. 2012. “Corporate Non-Income-Tax Avoidance.” Working Paper.

Scheiber, Noam. 2019. "Uber Drivers Are Contractors, Not Employees, Labor Board Says." The New York Times, May 14, 2019.

https://www.nytimes.com/2019/05/14/business/economy/nlrb-uber-drivers-contractors.html.

Simunic, Dan A. 1980. "The Pricing of Audit Services: Theory and Evidence.” Journal of Accounting Research 18 (1): 161-90.

Slemrod, Joel. 2007. "Cheating Ourselves : The Economics of Tax Evasion.” The Journal of Economic Perspectives 21 (1): 25-48.

Steingold, Fred S. 2017. Employer's Legal Handbook, The: Manage Your Employees \& 
Workplace Effectively Paperback. Berkeley, California: Nolo.

TIJTA. 2013. "Employers Do Not Always Follow Internal Revenue Service Worker Determination Rulings."

. 2018. "Additional Actions Are Needed to Make the Worker Misclassification Initiative With the Department of Labor a Success."

https://www.treasury.gov/tigta/iereports/2018reports/2018IER002fr.pdf.

U.S. Bureau of Labor Statistics. 2018. "Contingent and Alternative Employment Arrangements News Release." https://www.bls.gov/news.release/conemp.htm.

United States Department of Labor. 2015. "Wage and Hour Division Fact Sheet," no. January. https://www.dol.gov/WHD/overtime/final2016/overtime-factsheet.htm.

United States Government Accountability Office. 2006. "Employment Arrangements - Improved Outreach Could Help Ensure Proper Worker Classification."

http://www.gao.gov/new.items/d06656.pdf.

Wang, Fangjun, Shuolei Xu, Junqin Sun, and Charles P. Cullinan. 2019. "Corporate Tax Avoidance: A Literature Review and Research Agenda." Journal of Economic Surveys 0 (0): 1-19. https://doi.org/10.1111/joes.12347.

Weil, David. 2010. "Improving Workplace Conditions through Strategic Enforcement."

_ 2017. "Lots of Employees Get Misclassified as Contractors. Here's Why It Matters." Harvard Business Review. https://hbr.org/2017/07/lots-of-employees-get-misclassified-ascontractors-heres-why-it-matters.

WHD. 2014. "Fact Sheet \#13: Am I an Employee?: Employment Relationship Under the Fair Labor Standards Act (FLSA)." https://www.edola.org/wpcontent/uploads/2015/10/WageHourDivisionIndContractorFactSheet.pdf.

Wilde, Jaron H., and Ryan J. Wilson. 2018. "Perspectives on Corporate Tax Planning: Observations from the Past Decade." Journal of the American Taxation Association 40 (2): 63-81. https://doi.org/10.2308/ATAX-51993.

Wilson, Ryan J. 2009. "An Examination of Corporate Tax Shelter Participants.” Accounting Review 84 (3): 969-99. https://doi.org/10.2308/accr.2009.84.3.969.

Wolfolds, Sarah E, and Jordan Siegel. 2019. "Misaccounting for Endogeneity : The Peril of Relying on the Heckman Two-Step Method without a Valid Instrument." Strategic Management Journal, no. 40: 432-62. https://doi.org/10.1002/smj.2995.

Zaino, Gene. 2017. "When Misclassification Comes Your Way, Here's What To Do.” Forbes, November 6, 2017. 


\section{Appendices}

\section{Appendix 1 : Variable Definitions}

\begin{tabular}{|c|c|}
\hline Variable & Definition \\
\hline CashETR & $\begin{array}{l}\text { Cash taxes paid (txpd) divided by the sum of pre-tax } \\
\text { income (pi) }\end{array}$ \\
\hline COGSPercent & Cost of Goods Sold $(\operatorname{cog} s)$ divided by Net Sales (sale) \\
\hline Employees & Number of Employees (emp) divided by Net Sales (sale) \\
\hline SGA/Sales & $\begin{array}{l}\text { Selling, General and Administrative Expense (xsga) } \\
\text { divided by Net Sales (sale) }\end{array}$ \\
\hline Adv & $\begin{array}{l}\text { Advertising expense (xad) divided by total assets (at); } \\
\text { missing values set equal to zero }\end{array}$ \\
\hline Big4 & $\begin{array}{l}\text { Indicator Variable if the firm is audited by a Big } 4 \\
\text { Auditor }\end{array}$ \\
\hline CapInt & Net PPE (ppent) scaled by total assets (at) \\
\hline Equity Income & Equity income (esub) scaled by total assets (at) \\
\hline Foreign Income & $\begin{array}{l}\text { Indicator Variable if the firm had non-zero foreign } \\
\text { income (pifo) }\end{array}$ \\
\hline HPState & $\begin{array}{l}\text { Indicator Variable if the firm is headquarterd in a high } \\
\text { performing state. See: } \\
\text { https://www.dol.gov/newsroom/releases/eta/eta2014091 } \\
\underline{5}\end{array}$ \\
\hline IndustryMedianETR & $\begin{array}{l}\text { The median CASHETR for the firm's two-digit Standard } \\
\text { Industrial Classification Code (sictwo) }\end{array}$ \\
\hline Intangibles & $\begin{array}{l}\text { Intangibles (intan) scaled by total assets (at); missing } \\
\text { values set equal to zero }\end{array}$ \\
\hline Leverage & Long-term debt (dltt)) scaled by total assets (at) \\
\hline
\end{tabular}




\begin{tabular}{|c|c|}
\hline Loss Firm & $\begin{array}{l}\text { Indicator Variable if the firm had missing pre-tax } \\
\text { income (pi) }\end{array}$ \\
\hline LossIntensity & $\begin{array}{l}\text { Loss intensity over the previous four-year period defined } \\
\text { as the number of years a firm has negative pre-tax book } \\
\text { income (pi) from year } t-4 \text { to year } t-1 \text { scaled to range } \\
\text { from }[0,1]\end{array}$ \\
\hline MedianIncomeGreaterthenFederal & $\begin{array}{l}\text { Indicator Variable if the corporate headquarter state } \\
\text { median income is greater then US federal level for a } \\
\text { given year }\end{array}$ \\
\hline MinWageGreaterthenFederal & $\begin{array}{l}\text { Indicator Variable if the corporate headquarter state } \\
\text { minimum wage is greater then US federal level for a } \\
\text { given year }\end{array}$ \\
\hline MTB & $\begin{array}{l}\text { Market value of equity (Cprcc_f*csho) divided by book } \\
\text { value of equity (ceq) }\end{array}$ \\
\hline Pension & $\begin{array}{l}\text { Indicator Variable if the firm had non-zero Pension and } \\
\text { Retirement Expense (xpr) }\end{array}$ \\
\hline PriorityIndustry & $\begin{array}{l}\text { Indicator Variable if the firm Industry Sector is } \\
\text { identified by Weil (2010) }\end{array}$ \\
\hline RD & $\begin{array}{l}R \& D \text { expense (xrd) scaled by total assets (at); missing } \\
\text { values are set equal to zero. }\end{array}$ \\
\hline ROA & Pre-tax book income (pi) divided by total assets (at) \\
\hline SalesGrowth & $\begin{array}{l}\text { Current year sale (sale) less lag Sales divided by lag } \\
\text { Sales }\end{array}$ \\
\hline Sictwo & Two-digit Standard Industrial Classification Code \\
\hline Size & Natural log of total assets (at) \\
\hline StateIncomeTax & $\begin{array}{l}\text { Indicator Variable if the corporate headquarter state has } \\
\text { state income taxes }\end{array}$ \\
\hline Union & $\begin{array}{l}\text { Indicator Variable if the firm had a Collective } \\
\text { Bargaining Agreements File } \\
\text { (https://www.dol.gov/agencies/olms/regs/compliance/cb } \\
\text { a) }\end{array}$ \\
\hline
\end{tabular}




\section{Figures}

Figure 1: Trend of WHD Audits

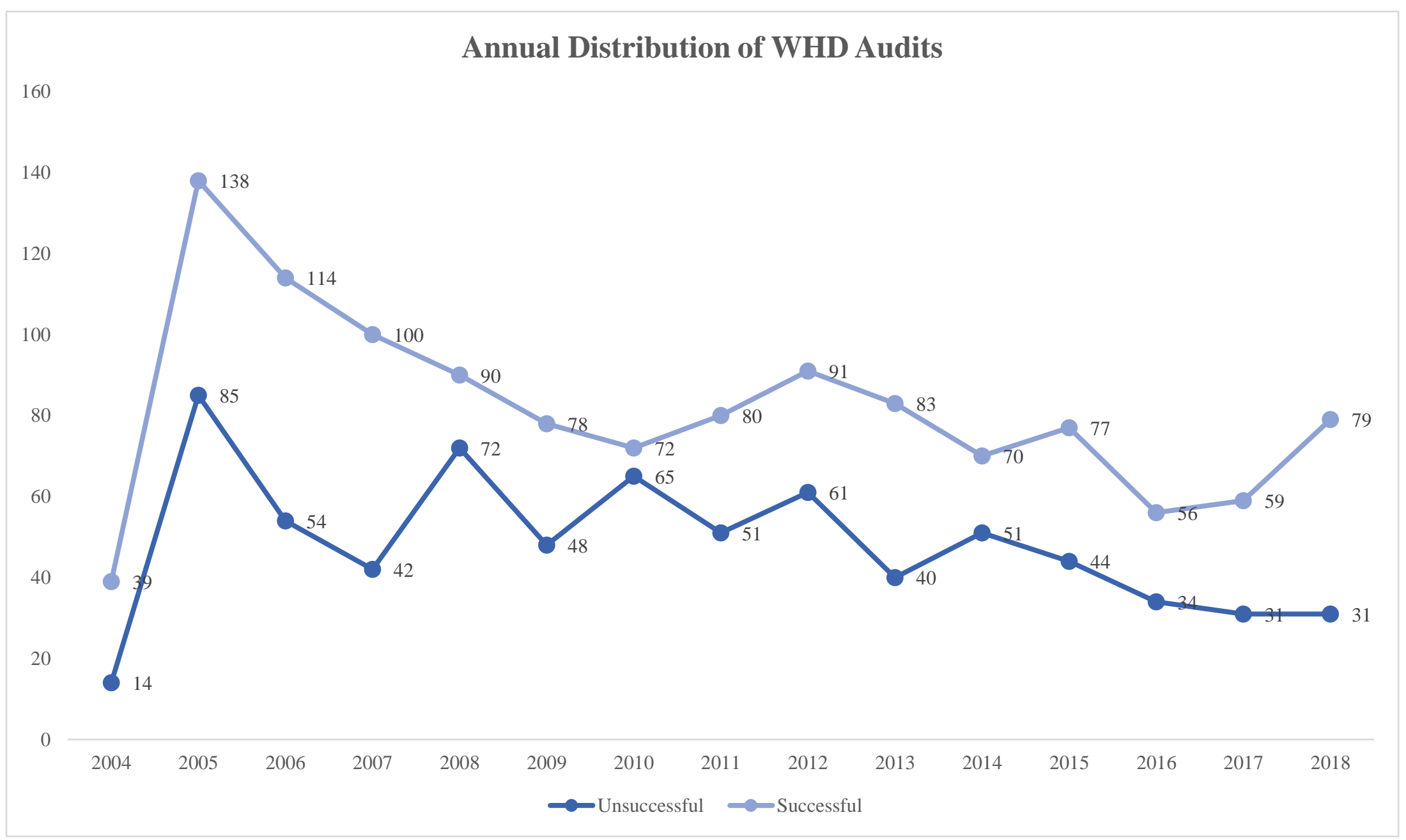


Figure 2: Trend of WHD Violations

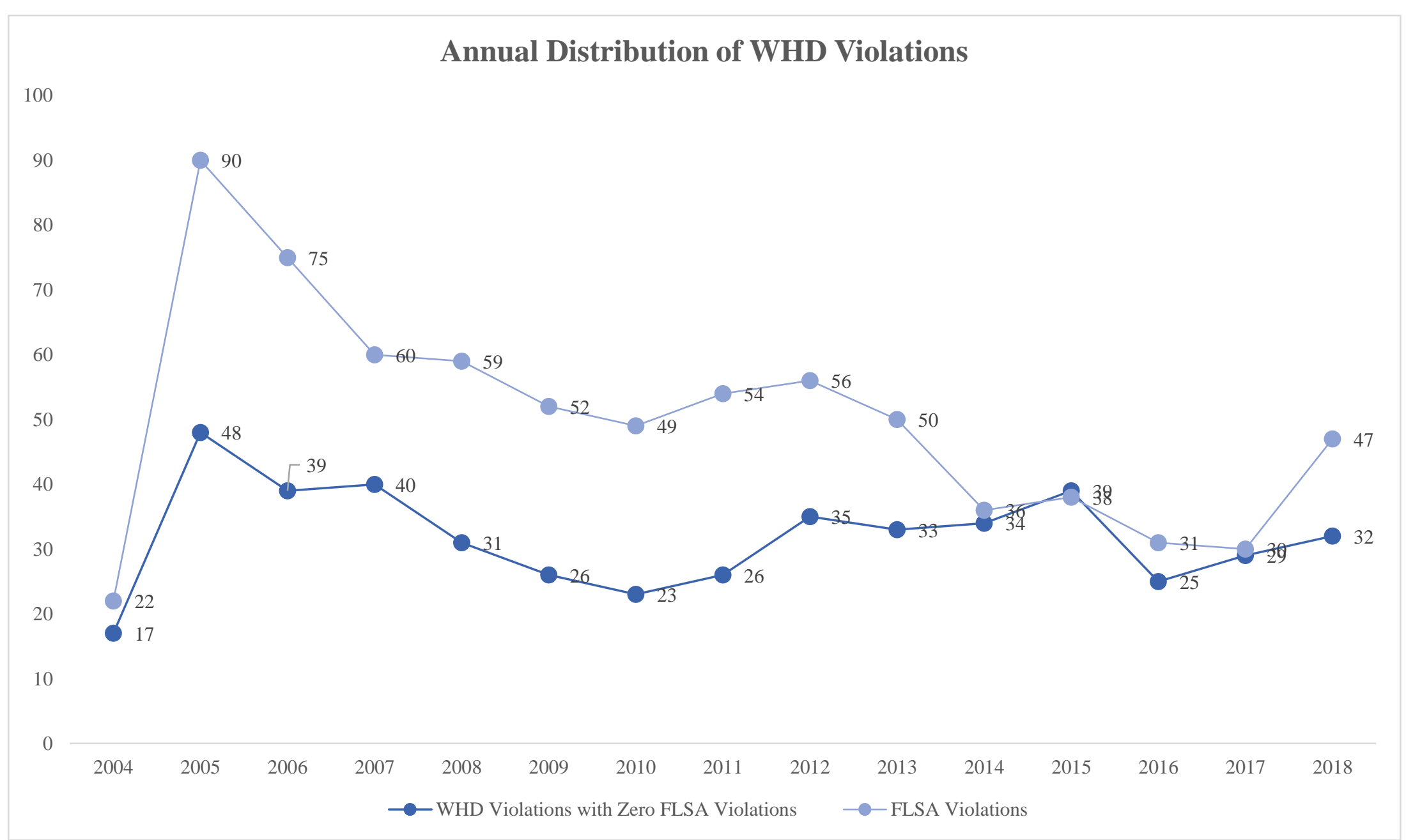


Figure 3: Industry Distribution of WHD Audits

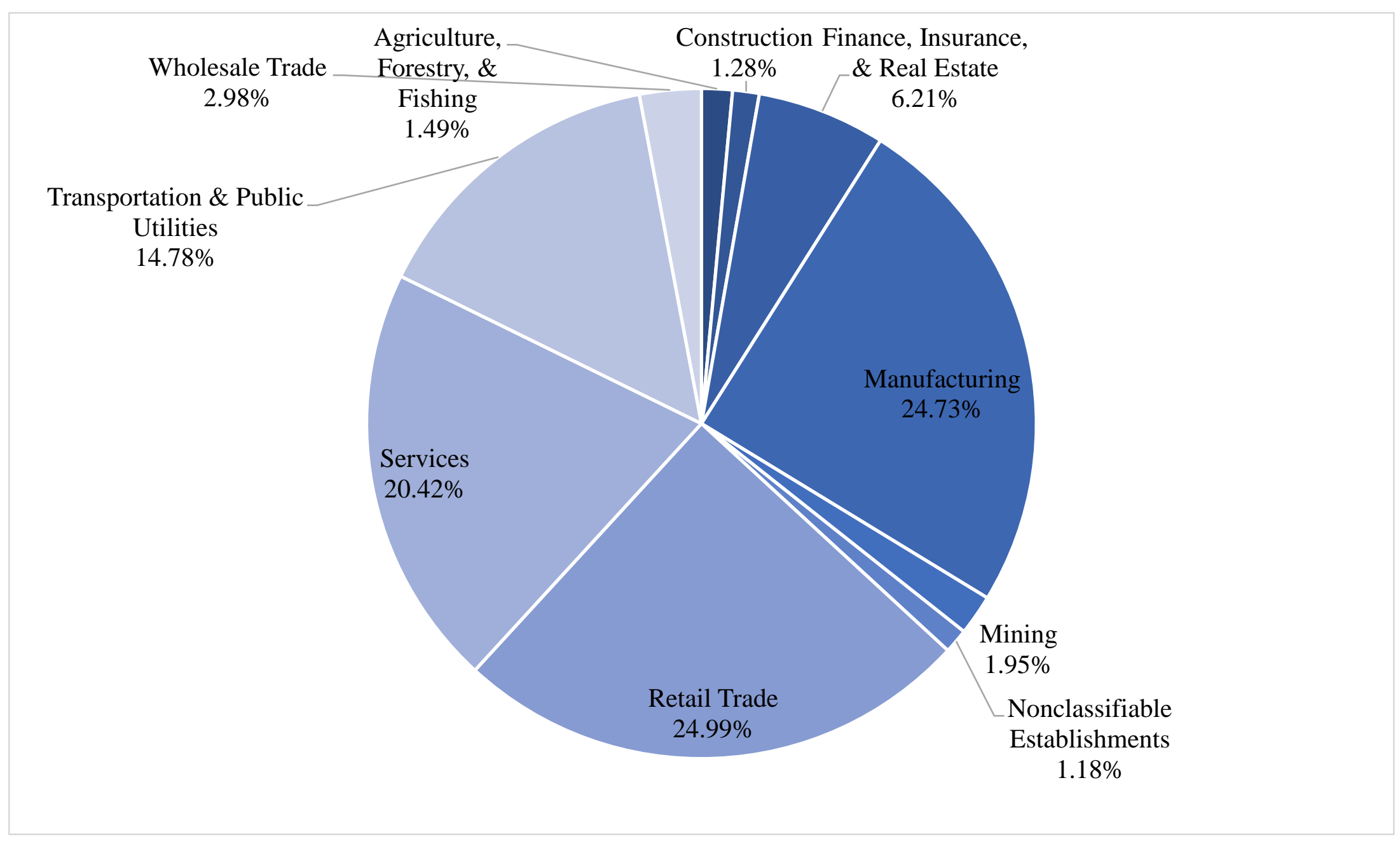




\section{Figure 4: Industry Distribution of FLSA Violations}

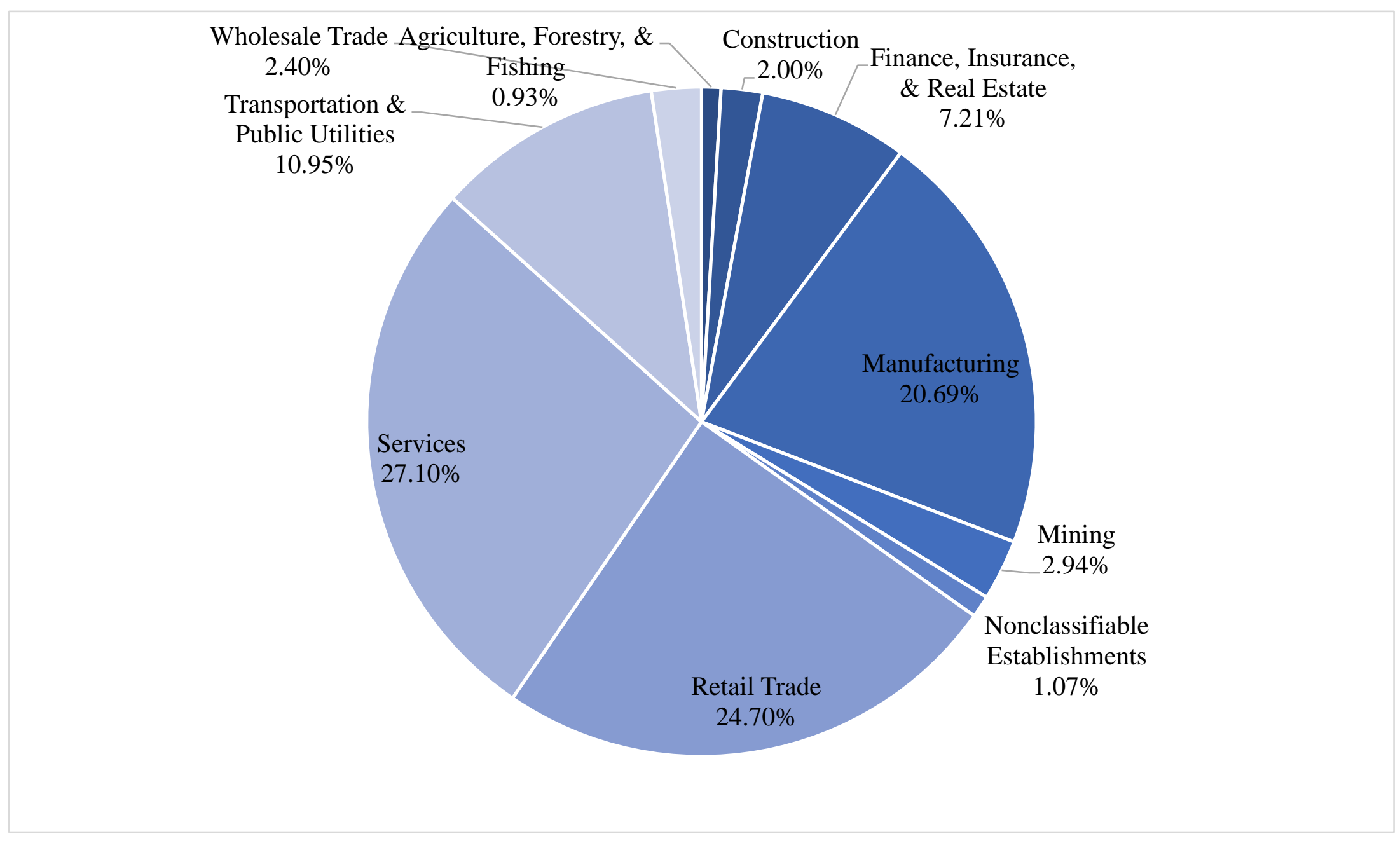




\section{Tables}

\section{Table 1: Sample Selection}

Detailed variable definitions are presented in Appendix 1

\# Obs.

Number of Publicly Matched WHD Audits

Less: "Duplicate" Audits***

Less: Audit Ended after 2018

Less: Observations missing/Duplicates from Compustat

Less: Observations with missing Pre-Tax Income

Less: Observations missing Cash Taxes Paid

Less: Observations with Cash Taxes Paid $<0 \%$

Less: Observations with Cash Taxes Paid $>100 \%$

*** The duplicate audits represent observations for firms that have had multiple audits over the given year. Given that tests are conducted at the firm-year level, I only require the cumulative audit result for a given year. As such, I aggregate the number of WHD violations for each firm in a given year irrespective of how many WHD Audits they endure. 


\section{Table 2: Sample Distribution}

Detailed variable definitions are presented in Appendix 1.

Panel A: Annual Distribution of WHD Audits

\begin{tabular}{|c|c|c|c|c|c|c|}
\hline \multirow[t]{2}{*}{ Year } & \multicolumn{2}{|c|}{$\begin{array}{c}\text { Unsuccessful Audit } \\
\text { (i.e., WHD Violations < } \\
\text { 0) }\end{array}$} & \multicolumn{2}{|c|}{$\begin{array}{c}\text { Successful Audit } \\
\text { (i.e., WHD Violations }>0 \text { ) }\end{array}$} & \multicolumn{2}{|c|}{ Total } \\
\hline & Count & $\%$ & Count & $\%$ & Count & $\%$ \\
\hline 2004 & 14 & $0.72 \%$ & 39 & $2.00 \%$ & 53 & $2.72 \%$ \\
\hline 2005 & 85 & $4.36 \%$ & 138 & $7.08 \%$ & 223 & $11.44 \%$ \\
\hline 2006 & 54 & $2.77 \%$ & 114 & $5.85 \%$ & 168 & $8.62 \%$ \\
\hline 2007 & 42 & $2.15 \%$ & 100 & $5.13 \%$ & 142 & $7.29 \%$ \\
\hline 2008 & 72 & $3.69 \%$ & 90 & $4.62 \%$ & 162 & $8.31 \%$ \\
\hline 2009 & 48 & $2.46 \%$ & 78 & $4.00 \%$ & 126 & $6.46 \%$ \\
\hline 2010 & 65 & $3.34 \%$ & 72 & $3.69 \%$ & 137 & $7.03 \%$ \\
\hline 2011 & 51 & $2.62 \%$ & 80 & $4.10 \%$ & 131 & $6.72 \%$ \\
\hline 2012 & 61 & $3.13 \%$ & 91 & $4.67 \%$ & 152 & $7.80 \%$ \\
\hline 2013 & 40 & $2.05 \%$ & 83 & $4.26 \%$ & 123 & $6.31 \%$ \\
\hline 2014 & 51 & $2.62 \%$ & 70 & $3.59 \%$ & 121 & $6.21 \%$ \\
\hline 2015 & 44 & $2.26 \%$ & 77 & $3.95 \%$ & 121 & $6.21 \%$ \\
\hline 2016 & 34 & $1.74 \%$ & 56 & $2.87 \%$ & 90 & $4.62 \%$ \\
\hline 2017 & 31 & $1.59 \%$ & 59 & $3.03 \%$ & 90 & $4.62 \%$ \\
\hline \multirow[t]{2}{*}{2018} & 31 & $1.59 \%$ & 79 & $4.05 \%$ & 110 & $5.64 \%$ \\
\hline & 723 & $37.10 \%$ & 1,226 & $62.90 \%$ & 1,949 & $100.00 \%$ \\
\hline
\end{tabular}


Panel B: Year Distribution of WHD Violations

\begin{tabular}{|c|c|c|c|c|c|c|}
\hline \multirow[t]{2}{*}{ Year } & \multicolumn{2}{|c|}{$\begin{array}{c}\text { WHD Violations with } \\
\text { Zero FLSA Violations } \\
\text { (i.e., WHD Violations > } \\
\text { 0, FLSA Violations = 0) }\end{array}$} & \multicolumn{2}{|c|}{$\begin{array}{c}\text { FLSA Violations } \\
\text { (i.e., FLSA Violations >0) }\end{array}$} & \multicolumn{2}{|c|}{$\begin{array}{c}\text { Total WHD } \\
\text { Violations }\end{array}$} \\
\hline & Count & $\%$ & Count & $\%$ & Count & $\%$ \\
\hline 2004 & 17 & $1.39 \%$ & 22 & $1.79 \%$ & 39 & $3.18 \%$ \\
\hline 2005 & 48 & $3.92 \%$ & 90 & $7.34 \%$ & 138 & $11.26 \%$ \\
\hline 2006 & 39 & $3.18 \%$ & 75 & $6.12 \%$ & 114 & $9.30 \%$ \\
\hline 2007 & 40 & $3.26 \%$ & 60 & $4.89 \%$ & 100 & $8.16 \%$ \\
\hline 2008 & 31 & $2.53 \%$ & 59 & $4.81 \%$ & 90 & $7.34 \%$ \\
\hline 2009 & 26 & $2.12 \%$ & 52 & $4.24 \%$ & 78 & $6.36 \%$ \\
\hline 2010 & 23 & $1.88 \%$ & 49 & $4.00 \%$ & 72 & $5.87 \%$ \\
\hline 2011 & 26 & $2.12 \%$ & 54 & $4.40 \%$ & 80 & $6.53 \%$ \\
\hline 2012 & 35 & $2.85 \%$ & 56 & $4.57 \%$ & 91 & $7.42 \%$ \\
\hline 2013 & 33 & $2.69 \%$ & 50 & $4.08 \%$ & 83 & $6.77 \%$ \\
\hline 2014 & 34 & $2.77 \%$ & 36 & $2.94 \%$ & 70 & $5.71 \%$ \\
\hline 2015 & 39 & $3.18 \%$ & 38 & $3.10 \%$ & 77 & $6.28 \%$ \\
\hline 2016 & 25 & $2.04 \%$ & 31 & $2.53 \%$ & 56 & $4.57 \%$ \\
\hline 2017 & 29 & $2.37 \%$ & 30 & $2.45 \%$ & 59 & $4.81 \%$ \\
\hline \multirow[t]{2}{*}{2018} & 32 & $2.61 \%$ & 47 & $3.83 \%$ & 79 & $6.44 \%$ \\
\hline & 477 & $38.91 \%$ & 749 & $61.09 \%$ & 1,226 & $100.00 \%$ \\
\hline
\end{tabular}


Panel C: Industry Distribution of WHD Audits

\begin{tabular}{|c|c|c|c|c|c|c|}
\hline \multirow[t]{2}{*}{ Industry Sector*** } & \multicolumn{2}{|c|}{$\begin{array}{c}\text { WHD } \\
\text { Violations }=0\end{array}$} & \multicolumn{2}{|c|}{$\begin{array}{c}\text { WHD } \\
\text { Violations }>0\end{array}$} & \multicolumn{2}{|c|}{ Total } \\
\hline & Count & $\%$ & Count & $\%$ & Count & $\%$ \\
\hline Agriculture, Forestry, \& Fishing & 13 & $0.67 \%$ & 16 & $0.82 \%$ & 29 & $1.49 \%$ \\
\hline Construction & 10 & $0.51 \%$ & 15 & $0.77 \%$ & 25 & $1.28 \%$ \\
\hline Finance, Insurance, \& Real Estate & 41 & $2.10 \%$ & 80 & $4.10 \%$ & 121 & $6.21 \%$ \\
\hline Manufacturing & 178 & $9.13 \%$ & 304 & $15.60 \%$ & 482 & $24.73 \%$ \\
\hline Mining & 12 & $0.62 \%$ & 26 & $1.33 \%$ & 38 & $1.95 \%$ \\
\hline Nonclassifiable Establishments & 4 & $0.21 \%$ & 19 & $0.97 \%$ & 23 & $1.18 \%$ \\
\hline Retail Trade & 206 & $10.57 \%$ & 281 & $14.42 \%$ & 487 & $24.99 \%$ \\
\hline Services & 131 & $6.72 \%$ & 267 & $13.70 \%$ & 398 & $20.42 \%$ \\
\hline Transportation \& Public Utilities & 103 & $5.28 \%$ & 185 & $9.49 \%$ & 288 & $14.78 \%$ \\
\hline Wholesale Trade & 25 & $1.28 \%$ & 33 & $1.69 \%$ & 58 & $2.98 \%$ \\
\hline & 723 & $37.10 \%$ & 1,226 & $62.90 \%$ & 1,949 & $100.00 \%$ \\
\hline
\end{tabular}

Panel D: Industry Distribution of WHD Audits with Violations

\begin{tabular}{lcccccc}
\hline \multicolumn{1}{c}{ Industry Sector*** } & $\begin{array}{c}\text { WHD Violations } \\
\text { with Zero FLSA }\end{array}$ & \multicolumn{2}{c}{$\boldsymbol{F L S A ~ V i o l a t i o n s}$} & \multicolumn{2}{c}{$\begin{array}{c}\text { Total WHD } \\
\text { Violations }\end{array}$} \\
& $\begin{array}{l}\text { Violations } \\
\text { Count }\end{array}$ & $\mathbf{\%}$ & Count & \% & Count & $\%$ \\
\hline Agriculture, Forestry, \& Fishing & 9 & $0.73 \%$ & 7 & $0.57 \%$ & 16 & $1.31 \%$ \\
Construction & 0 & $0.00 \%$ & 15 & $1.22 \%$ & 15 & $1.22 \%$ \\
Finance, Insurance, \& Real Estate & 26 & $2.12 \%$ & 54 & $4.40 \%$ & 80 & $6.53 \%$ \\
Manufacturing & 149 & $12.15 \%$ & 155 & $12.64 \%$ & 304 & $24.80 \%$ \\
Mining & 4 & $0.33 \%$ & 22 & $1.79 \%$ & 26 & $2.12 \%$ \\
Nonclassifiable Establishments & 11 & $0.90 \%$ & 8 & $0.65 \%$ & 19 & $1.55 \%$ \\
Retail Trade & 96 & $7.83 \%$ & 185 & $15.09 \%$ & 281 & $22.92 \%$ \\
Services & 64 & $5.22 \%$ & 203 & $16.56 \%$ & 267 & $21.78 \%$ \\
Transportation \& Public Utilities & 103 & $8.40 \%$ & 82 & $6.69 \%$ & 185 & $15.09 \%$ \\
Wholesale Trade & 15 & $1.22 \%$ & 18 & $1.47 \%$ & 33 & $2.69 \%$ \\
& & & & & & \\
\hline
\end{tabular}

\footnotetext{
***For the multivariate tests, I classify firms into their 2-Digit SIC classification code. However, for brevity, this table reports the industry sector. The Gig Economy is often associated with technology firms and the potential for employee misclassification. These types of firms would be represented by a variety of industry sectors. For example: Alphabet (Services), Amazon (Retail Trade), Apple (Manufacturing), Facebook (Services), Microsoft (Services), and Uber (Transportation \& Public Utilities).
} 
Table 3: Descriptive Statistics

Detailed variable definitions are presented in Appendix 1.

\section{Panel A: All WHD Audits}

\begin{tabular}{|c|c|c|c|c|c|c|c|c|}
\hline Variables & $\underline{\mathbf{N}}$ & $\underline{\text { Mean }}$ & $\underline{\text { SD }}$ & $\underline{\text { Min }}$ & p25 & $\underline{\text { Median }}$ & p75 & $\underline{\operatorname{Max}}$ \\
\hline Adv & 1,939 & 0.015 & 0.026 & 0.000 & 0.000 & 0.002 & 0.021 & 0.140 \\
\hline Big4 & 1,935 & 0.885 & 0.319 & 0.000 & 1.000 & 1.000 & 1.000 & 1.000 \\
\hline CapIntensity & 1,927 & 0.345 & 0.250 & 0.006 & 0.125 & 0.297 & 0.529 & 0.900 \\
\hline CashETR & 1,474 & 0.264 & 0.164 & 0.000 & 0.150 & 0.270 & 0.356 & 0.811 \\
\hline COGSPercent & 1,891 & 0.681 & 0.172 & 0.152 & 0.592 & 0.707 & 0.810 & 1.006 \\
\hline Employees & 1,847 & 0.009 & 0.013 & 0.000 & 0.003 & 0.005 & 0.009 & 0.101 \\
\hline EquityIncome & 1,628 & 0.001 & 0.003 & -0.005 & 0.000 & 0.000 & 0.000 & 0.022 \\
\hline ForeignIncome & 1,967 & 0.463 & 0.499 & 0.000 & 0.000 & 0.000 & 1.000 & 1.000 \\
\hline HPState & 1,930 & 0.494 & 0.500 & 0.000 & 0.000 & 0.000 & 1.000 & 1.000 \\
\hline Intangibles & 1,939 & 0.178 & 0.203 & 0.000 & 0.012 & 0.095 & 0.287 & 0.736 \\
\hline Leverage & 1,922 & 0.238 & 0.200 & 0.000 & 0.084 & 0.214 & 0.339 & 0.952 \\
\hline LossFirm & 1,939 & 0.184 & 0.387 & 0.000 & 0.000 & 0.000 & 0.000 & 1.000 \\
\hline LossIntensity & 1,940 & 0.159 & 0.198 & 0.000 & 0.000 & 0.000 & 0.250 & 0.667 \\
\hline MinWageGreaterthenFederal & 1,930 & 0.507 & 0.500 & 0.000 & 0.000 & 1.000 & 1.000 & 1.000 \\
\hline MedianIncomeGreaterthenFederal & 1,930 & 0.520 & 0.500 & 0.000 & 0.000 & 1.000 & 1.000 & 1.000 \\
\hline MTB & 1,664 & 2.993 & 4.193 & -11.122 & 1.409 & 2.247 & 3.637 & 26.204 \\
\hline Pension & 1,967 & 0.909 & 0.288 & 0.000 & 1.000 & 1.000 & 1.000 & 1.000 \\
\hline PriorityIndustry & 1,967 & 0.347 & 0.476 & 0.000 & 0.000 & 0.000 & 1.000 & 1.000 \\
\hline $\mathrm{RD}$ & 1,939 & 0.008 & 0.021 & 0.000 & 0.000 & 0.000 & 0.000 & 0.125 \\
\hline ROA & 1,939 & 0.058 & 0.120 & -0.469 & 0.016 & 0.066 & 0.118 & 0.345 \\
\hline SalesGrowth & 1,866 & 0.062 & 0.162 & -0.420 & -0.010 & 0.051 & 0.118 & 0.849 \\
\hline SGAPercent & 1,698 & 0.203 & 0.139 & 0.014 & 0.097 & 0.174 & 0.272 & 0.774 \\
\hline Size & 1,939 & 8.127 & 2.076 & 3.168 & 6.611 & 8.040 & 9.648 & 13.395 \\
\hline StateIncomeTax & 1,930 & 0.753 & 0.431 & 0.000 & 1.000 & 1.000 & 1.000 & 1.000 \\
\hline Union & 1,967 & 0.120 & 0.325 & 0.000 & 0.000 & 0.000 & 0.000 & 1.000 \\
\hline
\end{tabular}


Panel B: FLSA Violations (i.e., Audits with FLSA Violations >0)

\begin{tabular}{|c|c|c|c|c|c|c|c|c|}
\hline Variables & $\underline{\mathbf{N}}$ & Mean & $\underline{\text { SD }}$ & $\underline{\text { Min }}$ & p25 & Median & p75 & $\underline{\text { Max }}$ \\
\hline $\mathrm{Adv}$ & 741 & 0.015 & 0.028 & 0.000 & 0.000 & 0.001 & 0.019 & 0.140 \\
\hline Big4 & 740 & 0.832 & 0.374 & 0.000 & 1.000 & 1.000 & 1.000 & 1.000 \\
\hline CapIntensity & 737 & 0.311 & 0.254 & 0.006 & 0.095 & 0.245 & 0.488 & 0.900 \\
\hline CashETR & 541 & 0.278 & 0.175 & 0.000 & 0.158 & 0.278 & 0.361 & 0.811 \\
\hline COGSPercent & 719 & 0.678 & 0.179 & 0.152 & 0.575 & 0.698 & 0.813 & 1.006 \\
\hline Employees & 701 & 0.011 & 0.016 & 0.000 & 0.003 & 0.006 & 0.011 & 0.101 \\
\hline EquityIncome & 632 & 0.001 & 0.003 & -0.005 & 0.000 & 0.000 & 0.000 & 0.022 \\
\hline ForeignIncome & 749 & 0.431 & 0.496 & 0.000 & 0.000 & 0.000 & 1.000 & 1.000 \\
\hline HPState & 735 & 0.536 & 0.499 & 0.000 & 0.000 & 1.000 & 1.000 & 1.000 \\
\hline Intangibles & 741 & 0.184 & 0.205 & 0.000 & 0.011 & 0.103 & 0.301 & 0.736 \\
\hline Leverage & 730 & 0.223 & 0.206 & 0.000 & 0.043 & 0.196 & 0.329 & 0.952 \\
\hline LossFirm & 741 & 0.227 & 0.419 & 0.000 & 0.000 & 0.000 & 0.000 & 1.000 \\
\hline LossIntensity & 743 & 0.163 & 0.202 & 0.000 & 0.000 & 0.000 & 0.250 & 0.667 \\
\hline MinWageGreaterthenFederal & 735 & 0.479 & 0.500 & 0.000 & 0.000 & 0.000 & 1.000 & 1.000 \\
\hline MedianIncomeGreaterthenFederal & 735 & 0.501 & 0.500 & 0.000 & 0.000 & 1.000 & 1.000 & 1.000 \\
\hline MTB & 665 & 3.017 & 4.365 & -11.122 & 1.280 & 2.140 & 3.624 & 26.204 \\
\hline Pension & 749 & 0.904 & 0.295 & 0.000 & 1.000 & 1.000 & 1.000 & 1.000 \\
\hline PriorityIndustry & 749 & 0.397 & 0.490 & 0.000 & 0.000 & 0.000 & 1.000 & 1.000 \\
\hline $\mathrm{RD}$ & 741 & 0.007 & 0.023 & 0.000 & 0.000 & 0.000 & 0.000 & 0.125 \\
\hline ROA & 741 & 0.047 & 0.136 & -0.469 & 0.008 & 0.061 & 0.121 & 0.345 \\
\hline SalesGrowth & 706 & 0.075 & 0.183 & -0.420 & -0.011 & 0.056 & 0.131 & 0.849 \\
\hline SGAPercent & 650 & 0.222 & 0.156 & 0.014 & 0.095 & 0.204 & 0.294 & 0.774 \\
\hline Size & 741 & 7.562 & 2.019 & 3.168 & 6.235 & 7.477 & 8.878 & 13.395 \\
\hline StateIncomeTax & 735 & 0.722 & 0.448 & 0.000 & 0.000 & 1.000 & 1.000 & 1.000 \\
\hline Union & 749 & 0.076 & 0.265 & 0.000 & 0.000 & 0.000 & 0.000 & 1.000 \\
\hline
\end{tabular}


Panel C: WHD Violations but Zero FLSA Violations (i.e., Audits with WHD >0 \& FLSA Violations = 0)

Detailed variable definitions are presented in Appendix 1.

\begin{tabular}{|c|c|c|c|c|c|c|c|c|}
\hline Variables & $\underline{\mathbf{N}}$ & $\underline{\text { Mean }}$ & $\underline{\text { SD }}$ & $\underline{\operatorname{Min}}$ & p25 & $\underline{\text { Median }}$ & p75 & $\underline{\operatorname{Max}}$ \\
\hline $\mathrm{Adv}$ & 476 & 0.012 & 0.021 & 0.000 & 0.000 & 0.002 & 0.016 & 0.140 \\
\hline Big4 & 474 & 0.922 & 0.269 & 0.000 & 1.000 & 1.000 & 1.000 & 1.000 \\
\hline CapIntensity & 472 & 0.368 & 0.243 & 0.006 & 0.152 & 0.336 & 0.563 & 0.900 \\
\hline CashETR & 375 & 0.245 & 0.163 & 0.000 & 0.114 & 0.247 & 0.351 & 0.811 \\
\hline COGSPercent & 468 & 0.687 & 0.164 & 0.152 & 0.617 & 0.713 & 0.798 & 1.006 \\
\hline Employees & 459 & 0.006 & 0.010 & 0.000 & 0.002 & 0.004 & 0.006 & 0.101 \\
\hline EquityIncome & 389 & 0.001 & 0.003 & -0.005 & 0.000 & 0.000 & 0.001 & 0.022 \\
\hline ForeignIncome & 477 & 0.507 & 0.500 & 0.000 & 0.000 & 1.000 & 1.000 & 1.000 \\
\hline HPState & 473 & 0.427 & 0.495 & 0.000 & 0.000 & 0.000 & 1.000 & 1.000 \\
\hline Intangibles & 476 & 0.173 & 0.196 & 0.000 & 0.019 & 0.098 & 0.273 & 0.736 \\
\hline Leverage & 473 & 0.241 & 0.181 & 0.000 & 0.103 & 0.225 & 0.348 & 0.952 \\
\hline LossFirm & 476 & 0.143 & 0.350 & 0.000 & 0.000 & 0.000 & 0.000 & 1.000 \\
\hline LossIntensity & 475 & 0.158 & 0.188 & 0.000 & 0.000 & 0.000 & 0.250 & 0.667 \\
\hline MinWageGreaterthenFederal & 473 & 0.520 & 0.500 & 0.000 & 0.000 & 1.000 & 1.000 & 1.000 \\
\hline MedianIncomeGreaterthenFederal & 473 & 0.507 & 0.500 & 0.000 & 0.000 & 1.000 & 1.000 & 1.000 \\
\hline MTB & 385 & 3.063 & 4.706 & -11.122 & 1.483 & 2.258 & 3.612 & 26.204 \\
\hline Pension & 477 & 0.948 & 0.223 & 0.000 & 1.000 & 1.000 & 1.000 & 1.000 \\
\hline PriorityIndustry & 477 & 0.275 & 0.447 & 0.000 & 0.000 & 0.000 & 1.000 & 1.000 \\
\hline $\mathrm{RD}$ & 476 & 0.009 & 0.012 & 0.000 & 0.000 & 0.000 & 0.005 & 0.125 \\
\hline ROA & 476 & 0.061 & 0.107 & -0.469 & 0.025 & 0.062 & 0.109 & 0.345 \\
\hline SalesGrowth & 463 & 0.046 & 0.146 & -0.420 & -0.015 & 0.043 & 0.098 & 0.849 \\
\hline SGAPercent & 413 & 0.187 & 0.120 & 0.014 & 0.101 & 0.165 & 0.245 & 0.774 \\
\hline Size & 476 & 8.825 & 2.085 & 3.352 & 7.264 & 9.003 & 10.270 & 13.395 \\
\hline StateIncomeTax & 473 & 0.770 & 0.422 & 0.000 & 1.000 & 1.000 & 1.000 & 1.000 \\
\hline Union & 477 & 0.203 & 0.403 & 0.000 & 0.000 & 0.000 & 0.000 & 1.000 \\
\hline
\end{tabular}


Panel D: WHD Audits with Zero Violations (i.e., Audits with Violations = 0)

Detailed variable definitions are presented in Appendix 1.

\begin{tabular}{|c|c|c|c|c|c|c|c|c|}
\hline Variables & $\underline{\mathbf{N}}$ & $\underline{\text { Mean }}$ & $\underline{\text { SD }}$ & $\underline{\operatorname{Min}}$ & p25 & $\underline{\text { Median }}$ & p75 & $\underline{\operatorname{Max}}$ \\
\hline $\mathrm{Adv}$ & 722 & 0.017 & 0.028 & 0.000 & 0.000 & 0.003 & 0.024 & 0.140 \\
\hline Big4 & 721 & 0.915 & 0.278 & 0.000 & 1.000 & 1.000 & 1.000 & 1.000 \\
\hline CapIntensity & 718 & 0.364 & 0.249 & 0.006 & 0.150 & 0.317 & 0.557 & 0.900 \\
\hline CashETR & 558 & 0.263 & 0.151 & 0.000 & 0.162 & 0.270 & 0.355 & 0.811 \\
\hline COGSPercent & 704 & 0.679 & 0.171 & 0.152 & 0.590 & 0.710 & 0.810 & 1.006 \\
\hline Employees & 687 & 0.008 & 0.011 & 0.000 & 0.002 & 0.005 & 0.009 & 0.101 \\
\hline EquityIncome & 607 & 0.001 & 0.003 & -0.005 & 0.000 & 0.000 & 0.000 & 0.022 \\
\hline ForeignIncome & 723 & 0.477 & 0.500 & 0.000 & 0.000 & 0.000 & 1.000 & 1.000 \\
\hline HPState & 722 & 0.494 & 0.500 & 0.000 & 0.000 & 0.000 & 1.000 & 1.000 \\
\hline Intangibles & 722 & 0.175 & 0.206 & 0.000 & 0.011 & 0.086 & 0.274 & 0.736 \\
\hline Leverage & 719 & 0.250 & 0.204 & 0.000 & 0.096 & 0.225 & 0.343 & 0.952 \\
\hline LossFirm & 722 & 0.166 & 0.373 & 0.000 & 0.000 & 0.000 & 0.000 & 1.000 \\
\hline LossIntensity & 722 & 0.157 & 0.200 & 0.000 & 0.000 & 0.000 & 0.250 & 0.667 \\
\hline MinWageGreaterthenFederal & 722 & 0.528 & 0.500 & 0.000 & 0.000 & 1.000 & 1.000 & 1.000 \\
\hline MedianIncomeGreaterthenFederal & 722 & 0.547 & 0.498 & 0.000 & 0.000 & 1.000 & 1.000 & 1.000 \\
\hline MTB & 614 & 2.922 & 3.629 & -11.122 & 1.494 & 2.337 & 3.682 & 26.204 \\
\hline Pension & 723 & 0.911 & 0.284 & 0.000 & 1.000 & 1.000 & 1.000 & 1.000 \\
\hline PriorityIndustry & 723 & 0.353 & 0.478 & 0.000 & 0.000 & 0.000 & 1.000 & 1.000 \\
\hline $\mathrm{RD}$ & 722 & 0.008 & 0.021 & 0.000 & 0.000 & 0.000 & 0.001 & 0.125 \\
\hline ROA & 722 & 0.067 & 0.109 & -0.469 & 0.023 & 0.073 & 0.119 & 0.345 \\
\hline SalesGrowth & 697 & 0.058 & 0.149 & -0.420 & -0.005 & 0.048 & 0.118 & 0.849 \\
\hline SGAPercent & 635 & 0.193 & 0.130 & 0.014 & 0.096 & 0.161 & 0.267 & 0.774 \\
\hline Size & 722 & 8.246 & 1.967 & 3.168 & 6.828 & 8.173 & 9.646 & 13.395 \\
\hline StateIncomeTax & 722 & 0.774 & 0.418 & 0.000 & 1.000 & 1.000 & 1.000 & 1.000 \\
\hline Union & 723 & 0.113 & 0.317 & 0.000 & 0.000 & 0.000 & 0.000 & 1.000 \\
\hline
\end{tabular}




\section{Panel E: Mean Comparison Between Successful and Unsuccessful WHD Audits}

This table presents the means for the sample of WHD Audits with Zero Violations and WHD Audits with Violations, and the difference for all variables between the two groups. Detailed variable definitions are presented in Appendix 1.

\begin{tabular}{lccc}
\hline \multicolumn{1}{c}{ Variables } & $\begin{array}{c}\text { WHD Audits } \\
\text { with } \\
\text { Violations } \\
\text { Mean }\end{array}$ & $\begin{array}{c}\text { WHD Audits } \\
\text { with Zero } \\
\text { Violations } \\
\text { Mean }\end{array}$ & MeanDiff \\
\hline Adv & & & \\
Big4 & 0.014 & 0.017 & $-0.003^{* * * *}$ \\
CapIntensity & 0.867 & 0.915 & $-0.048^{* * *}$ \\
CashETR & 0.333 & 0.364 & $-0.030^{* *}$ \\
COGSPercent & 0.264 & 0.263 & 0.001 \\
Employees & 0.682 & 0.679 & 0.003 \\
EquityIncome & 0.009 & 0.008 & 0.001 \\
ForeignIncome & 0.001 & 0.001 & 0 \\
HPState & 0.461 & 0.466 & -0.005 \\
Intangibles & 0.493 & 0.494 & -0.001 \\
Leverage & 0.18 & 0.175 & 0.004 \\
LossFirm & 0.23 & 0.25 & $-0.020^{* *}$ \\
LossIntensity & 0.194 & 0.166 & 0.028 \\
MinWageGreaterthenFederal & 0.161 & 0.157 & 0.004 \\
MedianIncomeGreaterthenFederal & 0.495 & 0.528 & -0.033 \\
MTB & 0.503 & 0.547 & $-0.044^{*}$ \\
Pension & 3.034 & 2.922 & 0.111 \\
PriorityIndustry & 0.921 & 0.889 & $0.032^{* *}$ \\
RD & 0.349 & 0.344 & 0.005 \\
ROA & 0.008 & 0.008 & -0.000 \\
SalesGrowth & 0.053 & 0.067 & $-0.014^{* *}$ \\
SGAPercent & 0.063 & 0.058 & 0.005 \\
Size & 0.208 & 0.193 & $0.015^{* *}$ \\
StateIncomeTax & 8.056 & 8.246 & $-0.190^{*}$ \\
Union & 0.741 & 0.774 & -0.033 \\
& 0.126 & 0.111 & 0.015 \\
\hline
\end{tabular}




\section{Panel F: Mean Comparison Between Successful and Unsuccessful WHD Audits}

This table presents the means for the sample of WHD Audits with Zero Violations and WHD Audits with FLSA Violations, and the difference for all variables between the two groups. Detailed variable definitions are presented in Appendix 1.

\begin{tabular}{|c|c|c|c|}
\hline Variables & $\begin{array}{c}\text { WHD Audits } \\
\text { with FLSA } \\
\text { Violations } \\
\text { Mean } \\
\end{array}$ & $\begin{array}{c}\text { WHD Audits } \\
\text { with Zero } \\
\text { Violations } \\
\text { Mean } \\
\end{array}$ & MeanDiff \\
\hline Adv & 0.015 & 0.017 & -0.002 \\
\hline Big4 & 0.832 & 0.915 & $-0.083 * * *$ \\
\hline CapIntensity & 0.311 & 0.364 & $-0.052 * * *$ \\
\hline CashETR & 0.278 & 0.263 & 0.015 \\
\hline COGSPercent & 0.678 & 0.679 & 0.000 \\
\hline Employees & 0.011 & 0.008 & $0.002 * * *$ \\
\hline EquityIncome & 0.001 & 0.001 & 0.000 \\
\hline ForeignIncome & 0.431 & 0.466 & -0.034 \\
\hline HPState & 0.536 & 0.494 & 0.042 \\
\hline Intangibles & 0.184 & 0.175 & 0.008 \\
\hline Leverage & 0.223 & 0.25 & $-0.026 * *$ \\
\hline LossFirm & 0.227 & 0.166 & $0.061 * * *$ \\
\hline LossIntensity & 0.163 & 0.157 & 0.006 \\
\hline MinWageGreaterthenFederal & 0.479 & 0.528 & $-0.049 *$ \\
\hline MedianIncomeGreaterthenFederal & 0.501 & 0.547 & $-0.046^{*}$ \\
\hline MTB & 3.017 & 2.922 & 0.094 \\
\hline Pension & 0.904 & 0.889 & 0.015 \\
\hline PriorityIndustry & 0.397 & 0.344 & $0.052 * *$ \\
\hline $\mathrm{RD}$ & 0.007 & 0.008 & -0.001 \\
\hline $\mathrm{ROA}$ & 0.047 & 0.067 & $-0.020 * * *$ \\
\hline SalesGrowth & 0.075 & 0.058 & $0.017 *$ \\
\hline SGAPercent & 0.222 & 0.193 & $0.029 * * *$ \\
\hline Size & 7.562 & 8.246 & $-0.684 * * *$ \\
\hline StateIncomeTax & 0.722 & 0.774 & $-0.052 * *$ \\
\hline Union & 0.076 & 0.111 & $-0.035 * *$ \\
\hline
\end{tabular}




\section{Panel G: Mean Comparison Between Audits with non FLSA Violations and FLSA Violations}

This table presents the means for the sample of WHD Audits with Zero Violations and WHD Audits with FLSA Violations, and the difference for all variables between the two groups. Detailed variable definitions are presented in Appendix 1.

\begin{tabular}{|c|c|c|c|}
\hline Variables & $\begin{array}{c}\text { WHD Audits } \\
\text { with } \\
\text { Violations but } \\
\text { not FLSA } \\
\text { Violations } \\
\text { Mean } \\
\end{array}$ & $\begin{array}{c}\text { WHD Audits } \\
\text { with FLSA } \\
\text { Violations } \\
\text { Mean } \\
\end{array}$ & MeanDiff \\
\hline Adv & 0.015 & 0.012 & $0.004 * *$ \\
\hline Big4 & 0.832 & 0.922 & $-0.090 * * *$ \\
\hline CapIntensity & 0.311 & 0.368 & $-0.057 * * *$ \\
\hline CashETR & 0.278 & 0.245 & $0.033 * * *$ \\
\hline COGSPercent & 0.678 & 0.687 & -0.009 \\
\hline Employees & 0.011 & 0.006 & $0.004 * * *$ \\
\hline EquityIncome & 0.001 & 0.001 & $-0.000 * *$ \\
\hline ForeignIncome & 0.431 & 0.489 & $-0.058 * *$ \\
\hline HPState & 0.536 & 0.427 & $0.109 * * *$ \\
\hline Intangibles & 0.184 & 0.173 & 0.011 \\
\hline Leverage & 0.223 & 0.241 & -0.017 \\
\hline LossFirm & 0.227 & 0.143 & $0.084 * * *$ \\
\hline LossIntensity & 0.163 & 0.158 & 0.005 \\
\hline MinWageGreaterthenFederal & 0.479 & 0.52 & -0.041 \\
\hline MedianIncomeGreaterthenFederal & 0.501 & 0.507 & -0.007 \\
\hline MTB & 3.017 & 3.063 & -0.047 \\
\hline Pension & 0.904 & 0.913 & -0.009 \\
\hline PriorityIndustry & 0.397 & 0.265 & $0.132 * * *$ \\
\hline $\mathrm{RD}$ & 0.007 & 0.009 & -0.001 \\
\hline ROA & 0.047 & 0.061 & $-0.014 *$ \\
\hline SalesGrowth & 0.075 & 0.046 & $0.029 * * *$ \\
\hline SGAPercent & 0.222 & 0.187 & $0.035 * * *$ \\
\hline Size & 7.562 & 8.825 & $-1.263 * * *$ \\
\hline StateIncomeTax & 0.722 & 0.770 & $-0.047 *$ \\
\hline Union & 0.076 & 0.196 & $-0.120 * * *$ \\
\hline
\end{tabular}




\section{Table 4: First Stage Model of the Determinants of a WHD Audit}

This table presents the Probit regression results for modelling the likelihood of being audited by the Department of Labor. P-values are presented in parentheses. ***,**,* denote significance at $1 \%, 5 \%$, and $10 \%$ levels, respectively. Detailed variable definitions are presented in Appendix 1.

\begin{tabular}{|c|c|c|}
\hline VARIABLES & All Observations & $\begin{array}{c}\text { Observations with } \\
\text { CashETR }\end{array}$ \\
\hline Size & $\begin{array}{c}0.208 * * * \\
0.000\end{array}$ & $\begin{array}{c}0.217 * * * \\
0.000\end{array}$ \\
\hline ROA & $\begin{array}{c}0.228 * \\
0.054\end{array}$ & $\begin{array}{l}0.785 * * * \\
0.000\end{array}$ \\
\hline МTB & $\begin{array}{l}0.001 \\
0.650\end{array}$ & $\begin{array}{l}0.000 \\
0.981\end{array}$ \\
\hline Leverage & $\begin{array}{c}-0.498 * * * \\
0.000\end{array}$ & $\begin{array}{l}-0.572 * * * \\
0.000\end{array}$ \\
\hline ForeignIncome & $\begin{array}{c}-0.100 * * * \\
0.001\end{array}$ & $\begin{array}{c}-0.096 * * * \\
0.008\end{array}$ \\
\hline CapIntensity & $\begin{array}{l}0.274 * * * \\
0.000\end{array}$ & $\begin{array}{l}0.399 * * * \\
0.000\end{array}$ \\
\hline Employees & $\begin{array}{c}14.834 * * * \\
0.000\end{array}$ & $\begin{array}{c}15.246 * * * \\
0.000\end{array}$ \\
\hline EquityIncome & $\begin{array}{c}-12.296 * * * \\
0.000\end{array}$ & $\begin{array}{c}-16.461 * * * \\
0.000\end{array}$ \\
\hline Intangibles & $\begin{array}{c}-0.230 * * * \\
0.004\end{array}$ & $\begin{array}{c}-0.095 \\
0.315\end{array}$ \\
\hline $\mathrm{RD}$ & $\begin{array}{l}-4.115 * * * \\
0.000\end{array}$ & $\begin{array}{l}-4.894 * * * \\
0.000\end{array}$ \\
\hline COGSPercent & $\begin{array}{l}0.030 \\
0.103\end{array}$ & $\begin{array}{c}0.072 * * \\
0.025\end{array}$ \\
\hline SGAPercent & $\begin{array}{c}-0.117 * * * \\
0.000\end{array}$ & $\begin{array}{c}-0.179 * * * \\
0.001\end{array}$ \\
\hline SalesGrowth & $\begin{array}{l}-0.301 * * * \\
0.000\end{array}$ & $\begin{array}{c}-0.465 * * * \\
0.000\end{array}$ \\
\hline LossFirm & $\begin{array}{c}-0.030 \\
0.485\end{array}$ & $\begin{array}{l}0.043 \\
0.591\end{array}$ \\
\hline LossIntensity & $\begin{array}{c}-0.128 * * \\
0.049\end{array}$ & $\begin{array}{c}-0.056 \\
0.459\end{array}$ \\
\hline Big4 & $\begin{array}{l}0.022 \\
0.591\end{array}$ & $\begin{array}{l}0.019 \\
0.702\end{array}$ \\
\hline Pension & $\begin{array}{c}0.194 * * * \\
0.000\end{array}$ & $\begin{array}{c}0.211 * * * \\
0.000\end{array}$ \\
\hline Union & $\begin{array}{c}0.468 * * * \\
0.000\end{array}$ & $\begin{array}{l}0.505^{* * *} \\
0.000\end{array}$ \\
\hline MinWageGreaterthenFederal & $0.054^{*}$ & $0.075^{* *}$ \\
\hline
\end{tabular}




\begin{tabular}{l|c|c} 
& 0.069 & 0.027 \\
MedianIncomeGreaterthenFederal & 0.007 & -0.003 \\
HPState & 0.814 & 0.924 \\
PriorityIndustry & $-0.069^{* *}$ & $-0.066^{* *}$ \\
& 0.011 & 0.034 \\
Constant & $0.293^{* * *}$ & $0.278^{* * *}$ \\
& 0.000 & 0.000 \\
\hline Number of observations & $-3.388^{* * *}$ & $-3.57 * * *$ \\
Pseudo R2 & 0.000 & 0.000 \\
\hline
\end{tabular}




\section{Table 5: Second Stage Model of the Determinants of a Violation being Detected}

This table presents the Probit regression results for modelling the likelihood of being detecting for labor law violations while correcting for the potential selection bias of being Audited. P-values are presented in parentheses. ${ }^{* * *}, * *, *$ denote significance at $1 \%, 5 \%$, and $10 \%$ levels, respectively. Detailed variable definitions are presented in Appendix 1.

\begin{tabular}{|c|c|c|c|c|}
\hline \multirow{3}{*}{$\begin{array}{l}\text { VARIABLES } \\
\text { CashETR }\end{array}$} & \multicolumn{2}{|c|}{ WHDViolator } & \multicolumn{2}{|c|}{ FLSAViolator } \\
\hline & & 0.121 & & $0.289 * * *$ \\
\hline & & 0.227 & & 0.003 \\
\hline \multirow[t]{2}{*}{ Size } & 0.034 & 0.043 & -0.031 & -0.039 \\
\hline & 0.122 & 0.117 & 0.142 & 0.137 \\
\hline \multirow[t]{2}{*}{ ROA } & -0.077 & -0.063 & -0.19 & $-0.487 * *$ \\
\hline & 0.642 & 0.794 & 0.244 & 0.036 \\
\hline \multirow[t]{2}{*}{ МТB } & $0.005^{* *}$ & $0.006 * *$ & 0.003 & 0.003 \\
\hline & 0.023 & 0.01 & 0.1 & 0.141 \\
\hline \multirow[t]{2}{*}{ Leverage } & -0.103 & -0.125 & -0.069 & -0.107 \\
\hline & 0.257 & 0.268 & 0.433 & 0.326 \\
\hline \multirow[t]{2}{*}{ ForeignIncome } & -0.044 & -0.055 & -0.028 & -0.012 \\
\hline & 0.202 & 0.171 & 0.409 & 0.756 \\
\hline \multirow[t]{2}{*}{ CapIntensity } & -0.111 & -0.045 & -0.108 & -0.109 \\
\hline & 0.159 & 0.658 & 0.159 & 0.265 \\
\hline \multirow[t]{2}{*}{ Employees } & $3.137 *$ & $3.552 *$ & 1.754 & 0.883 \\
\hline & 0.069 & 0.088 & 0.293 & 0.656 \\
\hline \multirow[t]{2}{*}{ EquityIncome } & 0.998 & -0.992 & 2.29 & 3.312 \\
\hline & 0.782 & 0.815 & 0.515 & 0.417 \\
\hline \multirow[t]{2}{*}{ Intangibles } & -0.009 & 0.035 & 0.025 & 0.006 \\
\hline & 0.919 & 0.726 & 0.768 & 0.951 \\
\hline \multirow[t]{2}{*}{$\mathrm{RD}$} & $-1.556 * *$ & $-2.103 * *$ & $-1.224^{*}$ & -1.344 \\
\hline & 0.039 & 0.038 & 0.097 & 0.169 \\
\hline \multirow[t]{2}{*}{ COGSPercent } & -0.037 & 0.008 & $-0.164 *$ & -0.166 \\
\hline & 0.696 & 0.967 & 0.081 & 0.361 \\
\hline \multirow[t]{2}{*}{ SGAPercent } & 0.025 & 0.158 & -0.05 & 0.03 \\
\hline & 0.69 & 0.482 & 0.417 & 0.893 \\
\hline \multirow[t]{2}{*}{ SalesGrowth } & -0.069 & -0.111 & 0.114 & 0.138 \\
\hline & 0.376 & 0.386 & 0.131 & 0.263 \\
\hline \multirow[t]{2}{*}{ LossFirm } & 0.022 & -0.018 & 0.01 & -0.12 \\
\hline & 0.656 & 0.849 & 0.837 & 0.18 \\
\hline \multirow[t]{2}{*}{ LossIntensity } & 0.076 & 0.071 & 0.028 & 0.023 \\
\hline & 0.25 & 0.339 & 0.663 & 0.744 \\
\hline \multirow[t]{2}{*}{ Big4 } & $-0.074 *$ & $-0.089 *$ & -0.025 & -0.027 \\
\hline & 0.095 & 0.094 & 0.567 & 0.593 \\
\hline \multirow[t]{2}{*}{ Pension } & 0.068 & 0.093 & -0.02 & -0.027 \\
\hline & 0.227 & 0.167 & 0.712 & 0.678 \\
\hline Union & $0.123 *$ & $0.132^{*}$ & $-0.107^{*}$ & -0.112 \\
\hline
\end{tabular}




\begin{tabular}{c|cc|cc} 
& 0.066 & 0.094 & 0.099 & 0.138 \\
MinWageGreaterthenFederal & -0.025 & -0.04 & -0.03 & -0.053 \\
MedianIncomeGreaterthenFederal & 0.412 & 0.253 & 0.314 & 0.114 \\
Constant & -0.025 & -0.016 & -0.027 & -0.012 \\
& 0.402 & 0.647 & 0.349 & 0.724 \\
\hline Number of Observations & 0.048 & -0.151 & $0.811^{*}$ & $0.928^{*}$ \\
\hline Prob > chi2 & 0.909 & 0.792 & 0.05 & 0.093 \\
\hline & 46,850 & 29,887 & 46,850 & 29,887 \\
\hline
\end{tabular}




\section{Table 6: Change in CashETR}

This table presents results for Equation (3) which tests the impact of discovering labor violations on firms' Cash ETR. The control group includes firms that were subjected to a WHD audit but for which no labor violations were found. P-values are presented in parentheses. ***, **, * denote significance at $1 \%, 5 \%$, and $10 \%$ levels, respectively. Detailed variable definitions are presented in Appendix 1.

\begin{tabular}{|c|c|c|c|c|}
\hline \multirow[t]{2}{*}{ VARIABLES } & \multicolumn{2}{|c|}{ WHD Violations } & \multicolumn{2}{|c|}{$\underline{\text { FLSA Violations }}$} \\
\hline & $\begin{array}{l}0.015 \\
(0.19)\end{array}$ & $\begin{array}{l}0.013 \\
(0.22)\end{array}$ & $\begin{array}{c}0.023 * \\
(0.06)\end{array}$ & $\begin{array}{c}0.021 * \\
(0.08)\end{array}$ \\
\hline Treat & $\begin{array}{l}-0.012 \\
(0.11)\end{array}$ & $\begin{array}{c}-0.010 \\
(0.16)\end{array}$ & $\begin{array}{c}-0.007 \\
(0.42)\end{array}$ & $\begin{array}{c}-0.008 \\
(0.35)\end{array}$ \\
\hline Post & $\begin{array}{l}-0.005 \\
(0.57)\end{array}$ & $\begin{array}{l}0.000 \\
(0.99)\end{array}$ & $\begin{array}{c}-0.008 \\
(0.44)\end{array}$ & $\begin{array}{r}-0.002 \\
(0.82)\end{array}$ \\
\hline size & $\begin{array}{c}0.001 \\
(0.49)\end{array}$ & $\begin{array}{c}0.004 * * \\
(0.02)\end{array}$ & $\begin{array}{c}0.006 * * * \\
(0.00)\end{array}$ & $\begin{array}{c}0.008 * * * \\
(0.00)\end{array}$ \\
\hline ForeignIncome & $\begin{array}{c}0.023 * * * \\
(0.00)\end{array}$ & $\begin{array}{c}0.027 * * * \\
(0.00)\end{array}$ & $\begin{array}{c}0.025 * * * \\
(0.00)\end{array}$ & $\begin{array}{c}0.030 * * * \\
(0.00)\end{array}$ \\
\hline Leverage & $\begin{array}{c}-0.067 * * * \\
(0.00)\end{array}$ & $\begin{array}{c}-0.061 * * * \\
(0.00)\end{array}$ & $\begin{array}{c}-0.083 * * * \\
(0.00)\end{array}$ & $\begin{array}{c}-0.083 * * * \\
(0.00)\end{array}$ \\
\hline CapIntensity & $\begin{array}{c}-0.035 * * * \\
(0.01)\end{array}$ & $\begin{array}{c}-0.037 * \\
(0.08)\end{array}$ & $\begin{array}{c}-0.034^{* *} \\
(0.03)\end{array}$ & $\begin{array}{c}-0.036 \\
(0.11)\end{array}$ \\
\hline $\mathrm{RD}$ & $\begin{array}{c}-0.268 * * * \\
(0.00)\end{array}$ & $\begin{array}{c}-0.256 * * \\
(0.01)\end{array}$ & $\begin{array}{c}-0.219 * * * \\
(0.01)\end{array}$ & $\begin{array}{c}-0.211 * * \\
(0.04)\end{array}$ \\
\hline Adv & $\begin{array}{r}-0.077 \\
(0.39)\end{array}$ & $\begin{array}{c}-0.212^{* *} \\
(0.05)\end{array}$ & $\begin{array}{c}-0.002 \\
(0.98)\end{array}$ & $\begin{array}{c}-0.138 \\
(0.27)\end{array}$ \\
\hline Intangibles & $\begin{array}{l}0.000 \\
(0.98)\end{array}$ & $\begin{array}{l}0.012 \\
(0.52)\end{array}$ & $\begin{array}{c}-0.005 \\
(0.76)\end{array}$ & $\begin{array}{l}0.003 \\
(0.88)\end{array}$ \\
\hline ROA & $\begin{array}{c}0.022 * * * \\
(0.00)\end{array}$ & $\begin{array}{c}0.019 * * * \\
(0.00)\end{array}$ & $\begin{array}{c}0.018 * * * \\
(0.00)\end{array}$ & $\begin{array}{c}0.016 * * * \\
(0.00)\end{array}$ \\
\hline MTB & $\begin{array}{c}-0.000 \\
(0.29)\end{array}$ & $\begin{array}{c}-0.000 \\
(0.70)\end{array}$ & $\begin{array}{r}-0.001 \\
(0.19)\end{array}$ & $\begin{array}{c}-0.000 \\
(0.69)\end{array}$ \\
\hline EquityIncome & $\begin{array}{l}-0.615 \\
(0.34)\end{array}$ & $\begin{array}{c}-1.510 * * \\
(0.01)\end{array}$ & $\begin{array}{l}-0.176 \\
(0.82)\end{array}$ & $\begin{array}{c}-1.259 * \\
(0.10)\end{array}$ \\
\hline LossIntensity & $\begin{array}{l}0.014 \\
(0.27)\end{array}$ & $\begin{array}{c}-0.034 \\
(0.21)\end{array}$ & $\begin{array}{l}0.014 \\
(0.34)\end{array}$ & $\begin{array}{c}-0.021 \\
(0.47)\end{array}$ \\
\hline IndustryMedianETR & $\begin{array}{c}0.412 * * * \\
(0.00)\end{array}$ & $\begin{array}{c}0.520 * * * \\
(0.00)\end{array}$ & $\begin{array}{c}0.415^{* * *} * \\
(0.00)\end{array}$ & $\begin{array}{c}0.546 * * * \\
(0.00)\end{array}$ \\
\hline Constant & $\begin{array}{c}0.195 * * * \\
(0.00)\end{array}$ & $\begin{array}{c}0.155 * * * \\
(0.00)\end{array}$ & $\begin{array}{c}0.161 * * * \\
(0.00)\end{array}$ & $\begin{array}{c}0.131 * * * \\
(0.00)\end{array}$ \\
\hline $\begin{array}{l}\text { Observations } \\
\text { Fixed Effects } \\
\text { Adj. R-squared }\end{array}$ & $\begin{array}{c}3,611 \\
\text { NO } \\
0.0878 \\
\end{array}$ & $\begin{array}{c}3,611 \\
\text { Industry \& Year } \\
0.152\end{array}$ & $\begin{array}{c}2,786 \\
\text { NO } \\
0.0970 \\
\end{array}$ & $\begin{array}{c}2,786 \\
\text { Industry \& Year } \\
0.155\end{array}$ \\
\hline
\end{tabular}


Table 7: Change in Employees/Sales following Violations

This table presents results for testing the impact of discovering labor violations on firms' Employee Intensity. The control group includes firms that were subjected to a WHD audit but for which no labor violations were found. P-values are presented in parentheses. ***,**,* denote significance at 1\%, 5\%, and 10\%. Detailed variable definitions are presented in Appendix 1.

\begin{tabular}{|c|c|c|c|c|}
\hline \multirow[t]{2}{*}{ VARIABLES } & \multicolumn{2}{|c|}{ WHD Violations } & \multicolumn{2}{|c|}{$\underline{\text { FLSA Violations }}$} \\
\hline & $\begin{array}{l}0.001 \\
(0.20)\end{array}$ & $\begin{array}{l}\mathbf{0 . 0 0 1} \\
(0.13)\end{array}$ & $\begin{array}{c}0.002 * * \\
(0.05)\end{array}$ & $\begin{array}{c}0.002 * \\
(0.06)\end{array}$ \\
\hline Treat & $\begin{array}{l}0.001 * \\
(0.09)\end{array}$ & $\begin{array}{l}0.001 * \\
(0.06)\end{array}$ & $\begin{array}{c}0.001 * \\
(0.09)\end{array}$ & $\begin{array}{l}0.001 \\
(0.11)\end{array}$ \\
\hline Post & $\begin{array}{l}0.000 \\
(0.62)\end{array}$ & $\begin{array}{l}0.001 \\
(0.16)\end{array}$ & $\begin{array}{l}0.000 \\
(0.66)\end{array}$ & $\begin{array}{l}0.001 \\
(0.22)\end{array}$ \\
\hline size & $\begin{array}{c}-0.002 * * * \\
(0.00)\end{array}$ & $\begin{array}{c}-0.001 * * * \\
(0.00)\end{array}$ & $\begin{array}{c}-0.002 * * * \\
(0.00)\end{array}$ & $\begin{array}{c}-0.001 * * * \\
(0.00)\end{array}$ \\
\hline ForeignIncome & $\begin{array}{l}0.000 \\
(0.43)\end{array}$ & $\begin{array}{l}0.000 \\
(0.41)\end{array}$ & $\begin{array}{l}0.000 \\
(0.63)\end{array}$ & $\begin{array}{l}0.001 \\
(0.45)\end{array}$ \\
\hline Leverage & $\begin{array}{c}-0.002 * * \\
(0.04)\end{array}$ & $\begin{array}{c}-0.003^{* *} \\
(0.05)\end{array}$ & $\begin{array}{c}-0.003 * * \\
(0.02)\end{array}$ & $\begin{array}{c}-0.002 \\
(0.11)\end{array}$ \\
\hline CapIntensity & $\begin{array}{l}0.002 * * \\
(0.02)\end{array}$ & $\begin{array}{l}0.000 \\
(0.70)\end{array}$ & $\begin{array}{c}0.002^{*} \\
(0.06)\end{array}$ & $\begin{array}{l}-0.001 \\
(0.46)\end{array}$ \\
\hline Intangibles & $\begin{array}{c}-0.000 \\
(0.86)\end{array}$ & $\begin{array}{c}-0.005^{* * *} \\
(0.00)\end{array}$ & $\begin{array}{l}-0.001 \\
(0.58)\end{array}$ & $\begin{array}{c}-0.006 * * * \\
(0.00)\end{array}$ \\
\hline ROA & $\begin{array}{l}0.001 \\
(0.17)\end{array}$ & $\begin{array}{l}0.001 \\
(0.49)\end{array}$ & $\begin{array}{l}0.001 * \\
(0.07)\end{array}$ & $\begin{array}{l}0.001 \\
(0.14)\end{array}$ \\
\hline MTB & $\begin{array}{c}-0.000 \\
(0.87)\end{array}$ & $\begin{array}{c}-0.000 * \\
(0.08)\end{array}$ & $\begin{array}{c}-0.000 \\
(0.88)\end{array}$ & $\begin{array}{c}-0.000 * * \\
(0.02)\end{array}$ \\
\hline $\mathrm{RD}$ & $\begin{array}{c}0.027 * * * \\
(0.00)\end{array}$ & $\begin{array}{l}0.024 \\
(0.44)\end{array}$ & $\begin{array}{c}0.031 * * * \\
(0.00)\end{array}$ & $\begin{array}{l}0.025 \\
(0.49)\end{array}$ \\
\hline Pension & $\begin{array}{c}-0.004 * * * \\
(0.00)\end{array}$ & $\begin{array}{c}-0.003 * * \\
(0.02)\end{array}$ & $\begin{array}{c}-0.004 * * * \\
(0.00)\end{array}$ & $\begin{array}{c}-0.003^{*} \\
(0.06)\end{array}$ \\
\hline Union & $\begin{array}{r}-0.001 \\
(0.21)\end{array}$ & $\begin{array}{l}0.000 \\
(0.85)\end{array}$ & $\begin{array}{r}-0.001 \\
(0.17)\end{array}$ & $\begin{array}{l}0.000 \\
(0.76)\end{array}$ \\
\hline LossFirm & $\begin{array}{l}-0.000 \\
(0.47)\end{array}$ & $\begin{array}{l}0.000 \\
(0.96)\end{array}$ & $\begin{array}{c}-0.000 \\
(0.81)\end{array}$ & $\begin{array}{l}0.000 \\
(0.72)\end{array}$ \\
\hline MedianIncomeGreaterthenFederal & $\begin{array}{l}-0.001 \\
(0.11)\end{array}$ & $\begin{array}{r}-0.001 \\
(0.13)\end{array}$ & $\begin{array}{c}-0.001 * * \\
(0.04)\end{array}$ & $\begin{array}{c}-0.001 * * \\
(0.03)\end{array}$ \\
\hline MinWageGreaterthenFederal & $\begin{array}{c}0.001 * * \\
(0.01)\end{array}$ & $\begin{array}{c}0.001 * * * \\
(0.01)\end{array}$ & $\begin{array}{c}0.002 * * * \\
(0.00)\end{array}$ & $\begin{array}{c}0.002 * * * \\
(0.00)\end{array}$ \\
\hline stateIncomeTax & $\begin{array}{c}-0.000 \\
(0.88)\end{array}$ & $\begin{array}{c}0.001^{*} \\
(0.09)\end{array}$ & $\begin{array}{l}0.000 \\
(0.87)\end{array}$ & $\begin{array}{l}0.001 \\
(0.12)\end{array}$ \\
\hline Constant & $\begin{array}{c}0.025 * * * \\
(0.00)\end{array}$ & $\begin{array}{c}0.024 * * * \\
(0.00)\end{array}$ & $\begin{array}{c}0.025 * * * \\
(0.00) \\
\end{array}$ & $\begin{array}{c}0.022 * * * \\
(0.00)\end{array}$ \\
\hline $\begin{array}{l}\text { Observations } \\
\text { Fixed Effects } \\
\text { Adj. R-squared }\end{array}$ & $\begin{array}{c}5,218 \\
\mathrm{NO} \\
0.0827\end{array}$ & $\begin{array}{c}5,218 \\
\text { Industry \& Year } \\
0.240\end{array}$ & $\begin{array}{c}4,013 \\
\mathrm{NO} \\
0.0827\end{array}$ & $\begin{array}{c}4,013 \\
\text { Industry \& Year } \\
0.231\end{array}$ \\
\hline
\end{tabular}




\section{Table 8: Change in Cost Classification}

These tables present results for testing the impact of discovering labor violations on firms' cost classification and profitability. The control group includes firms that were subjected to a WHD audit but for which no labor violations were found. P-values are presented in parentheses. ***, **, * denote significance at $1 \%, 5 \%$, and $10 \%$. Detailed variable definitions are presented in Appendix 1.

\section{Panel A: Product Costs (COGS/Sales)}

\begin{tabular}{|c|c|c|c|c|}
\hline \multirow{3}{*}{$\begin{array}{l}\text { VARIABLES } \\
\text { DiD }\end{array}$} & \multicolumn{2}{|c|}{ WHD Violations } & \multicolumn{2}{|c|}{ FLSA Violations } \\
\hline & 0.017 & $0.015 *$ & 0.014 & 0.015 \\
\hline & $(\mathbf{0 . 1 0})$ & $(0.09)$ & $(0.23)$ & $(0.10)$ \\
\hline \multirow[t]{2}{*}{ Treat } & -0.007 & -0.002 & -0.007 & 0.002 \\
\hline & $(0.30)$ & $(0.74)$ & $(0.38)$ & $(0.80)$ \\
\hline \multirow[t]{2}{*}{ Post } & -0.004 & 0.001 & -0.003 & 0.002 \\
\hline & $(0.64)$ & $(0.85)$ & $(0.72)$ & $(0.77)$ \\
\hline \multirow[t]{2}{*}{ SalesGrowth } & -0.011 & -0.020 & -0.006 & -0.018 \\
\hline & $(0.16)$ & $(0.22)$ & $(0.46)$ & $(0.30)$ \\
\hline \multirow[t]{2}{*}{ size } & $-0.010 * * *$ & $-0.007 * * *$ & $-0.010 * * *$ & $-0.007 * * *$ \\
\hline & $(0.00)$ & $(0.00)$ & $(0.00)$ & $(0.00)$ \\
\hline \multirow[t]{2}{*}{ ForeignIncome } & $-0.024 * * *$ & $-0.024 * * *$ & $-0.024 * * *$ & $-0.019 * * *$ \\
\hline & $(0.00)$ & $(0.00)$ & $(0.00)$ & $(0.00)$ \\
\hline \multirow[t]{2}{*}{ Leverage } & $0.065 * * *$ & 0.025 & $0.072 * * *$ & $0.043 * *$ \\
\hline & $(0.00)$ & $(0.10)$ & $(0.00)$ & $(0.01)$ \\
\hline \multirow[t]{2}{*}{ CapIntensity } & $-0.061 * * *$ & $-0.145 * * *$ & $-0.064 * * *$ & $-0.168 * * *$ \\
\hline & $(0.00)$ & $(0.00)$ & $(0.00)$ & $(0.00)$ \\
\hline \multirow[t]{2}{*}{ Intangibles } & $-0.164 * * *$ & $-0.138 * * *$ & $-0.170 * * *$ & $-0.153 * * *$ \\
\hline & $(0.00)$ & $(0.00)$ & $(0.00)$ & $(0.00)$ \\
\hline \multirow[t]{2}{*}{ MTB } & -0.000 & $-0.001 * *$ & -0.000 & $-0.001 * *$ \\
\hline & $(0.66)$ & $(0.04)$ & $(0.57)$ & $(0.02)$ \\
\hline \multirow[t]{2}{*}{$\mathrm{RD}$} & $-0.906 * * *$ & $-0.622 * *$ & $-0.925 * * *$ & $-0.622 * *$ \\
\hline & $(0.00)$ & $(0.02)$ & $(0.00)$ & $(0.04)$ \\
\hline \multirow[t]{2}{*}{ ROA } & $-0.062 * * *$ & -0.059 & $-0.050 * * *$ & -0.044 \\
\hline & $(0.00)$ & $(0.14)$ & $(0.00)$ & $(0.15)$ \\
\hline \multirow[t]{2}{*}{ Adv } & $-1.264 * * *$ & $-1.167 * * *$ & $-1.115 * * *$ & $-1.040 * * *$ \\
\hline & $(0.00)$ & $(0.00)$ & $(0.00)$ & $(0.00)$ \\
\hline \multirow[t]{2}{*}{ Pension } & $0.038 * * *$ & $0.029 * * *$ & $0.042 * * *$ & $0.036 * * *$ \\
\hline & $(0.00)$ & $(0.00)$ & $(0.00)$ & $(0.00)$ \\
\hline \multirow[t]{2}{*}{ LossFirm } & $0.031 * * *$ & $0.035^{* * *} *$ & $0.028 * * *$ & $0.032 * * *$ \\
\hline & $(0.00)$ & $(0.00)$ & $(0.00)$ & $(0.00)$ \\
\hline \multirow[t]{2}{*}{ Union } & $0.093 * * *$ & $0.049 * * *$ & $0.097 * * *$ & $0.048 * * *$ \\
\hline & $(0.00)$ & $(0.00)$ & $(0.00)$ & $(0.00)$ \\
\hline \multirow[t]{2}{*}{ EquityIncome } & $2.175^{* * * *}$ & 0.555 & $3.229 * * *$ & $1.165^{*}$ \\
\hline & $(0.00)$ & $(0.39)$ & $(0.00)$ & $(0.10)$ \\
\hline \multirow[t]{2}{*}{ stateIncomeTax } & -0.007 & 0.004 & $-0.015^{* *}$ & 0.001 \\
\hline & $(0.20)$ & $(0.45)$ & $(0.03)$ & $(0.85)$ \\
\hline \multirow[t]{2}{*}{ Constant } & $0.787 * * *$ & $0.813 * * *$ & $0.789 * * *$ & $0.830 * * *$ \\
\hline & $(0.00)$ & $(0.00)$ & $(0.00)$ & $(0.00)$ \\
\hline Observations & 4,423 & 4,423 & 3,435 & 3,435 \\
\hline Fixed Effects & NO & Industry \& Year & NO & Industry \& Year \\
\hline Adj. R-squared & 0.167 & 0.413 & 0.155 & 0.432 \\
\hline
\end{tabular}




\begin{tabular}{|c|c|c|c|c|}
\hline \multirow{2}{*}{$\begin{array}{l}\text { VARIABLES } \\
\text { DiD }\end{array}$} & \multicolumn{2}{|c|}{$\underline{\text { WHD Violations }}$} & \multicolumn{2}{|c|}{$\underline{\text { FLSA Violations }}$} \\
\hline & $\begin{array}{c}-0.010 \\
(0.24)\end{array}$ & $\begin{array}{c}-0.011 \\
(0.11)\end{array}$ & $\begin{array}{c}-0.008 \\
(0.39)\end{array}$ & $\begin{array}{c}-0.011 \\
(0.15)\end{array}$ \\
\hline Treat & $\begin{array}{c}0.016^{* * *} * \\
(0.00)\end{array}$ & $\begin{array}{c}0.011 * * \\
(0.02)\end{array}$ & $\begin{array}{c}0.019 * * * \\
(0.00)\end{array}$ & $\begin{array}{c}0.009 * \\
(0.10)\end{array}$ \\
\hline Post & $\begin{array}{l}0.006 \\
(0.41)\end{array}$ & $\begin{array}{c}0.004 \\
(0.46)\end{array}$ & $\begin{array}{l}0.005 \\
(0.46)\end{array}$ & $\begin{array}{c}0.004 \\
(0.51)\end{array}$ \\
\hline SalesGrowth & $\begin{array}{c}0.018 * * * \\
(0.01)\end{array}$ & $\begin{array}{c}0.025 * * \\
(0.02)\end{array}$ & $\begin{array}{c}0.018^{* *} \\
(0.01)\end{array}$ & $\begin{array}{c}0.028 * * * \\
(0.00)\end{array}$ \\
\hline size & $\begin{array}{c}-0.004 * * * \\
(0.00)\end{array}$ & $\begin{array}{c}-0.007 * * * \\
(0.00)\end{array}$ & $\begin{array}{c}-0.005 * * * \\
(0.00)\end{array}$ & $\begin{array}{c}-0.009 * * * \\
(0.00)\end{array}$ \\
\hline ForeignIncome & $\begin{array}{c}-0.004 \\
(0.38)\end{array}$ & $\begin{array}{c}0.010 * * \\
(0.03)\end{array}$ & $\begin{array}{c}-0.002 \\
(0.64)\end{array}$ & $\begin{array}{c}0.009 * \\
(0.09)\end{array}$ \\
\hline Leverage & $\begin{array}{c}-0.086 * * * \\
(0.00)\end{array}$ & $\begin{array}{c}-0.043 * * * \\
(0.00)\end{array}$ & $\begin{array}{c}-0.092 * * * \\
(0.00)\end{array}$ & $\begin{array}{c}-0.050 * * * \\
(0.00)\end{array}$ \\
\hline CapIntensity & $\begin{array}{c}-0.069 * * * \\
(0.00)\end{array}$ & $\begin{array}{r}-0.009 \\
(0.57)\end{array}$ & $\begin{array}{c}-0.070 * * * \\
(0.00)\end{array}$ & $\begin{array}{l}0.003 \\
(0.88)\end{array}$ \\
\hline Intangibles & $\begin{array}{c}0.052 * * * \\
(0.00)\end{array}$ & $\begin{array}{c}0.055^{* * * *} \\
(0.00)\end{array}$ & $\begin{array}{c}0.057 * * * \\
(0.00)\end{array}$ & $\begin{array}{c}0.070 * * * \\
(0.00)\end{array}$ \\
\hline MTB & $\begin{array}{c}0.001 * * * \\
(0.01)\end{array}$ & $\begin{array}{c}0.001 * * * \\
(0.00)\end{array}$ & $\begin{array}{c}0.001 * * \\
(0.02)\end{array}$ & $\begin{array}{c}0.001 * * * \\
(0.01)\end{array}$ \\
\hline $\mathrm{RD}$ & $\begin{array}{c}1.623 * * * \\
(0.00)\end{array}$ & $\begin{array}{c}1.520 * * * \\
(0.00)\end{array}$ & $\begin{array}{c}1.749 * * * \\
(0.00)\end{array}$ & $\begin{array}{c}1.677 * * * \\
(0.00)\end{array}$ \\
\hline ROA & $\begin{array}{c}-0.043 * * * \\
(0.00)\end{array}$ & $\begin{array}{c}-0.065^{* *} \\
(0.04)\end{array}$ & $\begin{array}{c}-0.080 * * * \\
(0.00)\end{array}$ & $\begin{array}{c}-0.112 * * * \\
(0.00)\end{array}$ \\
\hline Adv & $\begin{array}{c}1.337 * * * \\
(0.00)\end{array}$ & $\begin{array}{c}1.019 * * * \\
(0.00)\end{array}$ & $\begin{array}{c}1.216^{* * *} * \\
(0.00)\end{array}$ & $\begin{array}{c}0.864 * * * \\
(0.00)\end{array}$ \\
\hline Pension & $\begin{array}{c}-0.051 * * * \\
(0.00)\end{array}$ & $\begin{array}{c}-0.049 * * * \\
(0.00)\end{array}$ & $\begin{array}{c}-0.050 * * * \\
(0.00)\end{array}$ & $\begin{array}{c}-0.050 * * * \\
(0.00)\end{array}$ \\
\hline LossFirm & $\begin{array}{c}0.044 * * * \\
(0.00)\end{array}$ & $\begin{array}{c}0.039 * * * \\
(0.00)\end{array}$ & $\begin{array}{c}0.040 * * * \\
(0.00)\end{array}$ & $\begin{array}{c}0.032 * * * \\
(0.00)\end{array}$ \\
\hline Union & $\begin{array}{c}-0.053 * * * \\
(0.00)\end{array}$ & $\begin{array}{c}-0.039 * * * \\
(0.00)\end{array}$ & $\begin{array}{c}-0.046 * * * \\
(0.00)\end{array}$ & $\begin{array}{c}-0.038 * * * \\
(0.00)\end{array}$ \\
\hline EquityIncome & $\begin{array}{c}-2.609 * * * \\
(0.00)\end{array}$ & $\begin{array}{c}-1.021^{* *} \\
(0.03)\end{array}$ & $\begin{array}{c}-3.590 * * * \\
(0.00)\end{array}$ & $\begin{array}{c}-1.521 * * * \\
(0.00)\end{array}$ \\
\hline stateIncomeTax & $\begin{array}{l}0.006 \\
(0.16)\end{array}$ & $\begin{array}{c}-0.004 \\
(0.30)\end{array}$ & $\begin{array}{c}0.012 * * \\
(0.03)\end{array}$ & $\begin{array}{r}-0.001 \\
(0.79)\end{array}$ \\
\hline Constant & $\begin{array}{c}0.263 * * * \\
(0.00)\end{array}$ & $\begin{array}{c}0.266 * * * \\
(0.00)\end{array}$ & $\begin{array}{c}0.264 * * * \\
(0.00)\end{array}$ & $\begin{array}{c}0.265^{* * *} * \\
(0.00)\end{array}$ \\
\hline $\begin{array}{l}\text { Observations } \\
\text { Fixed Effects } \\
\text { Adj. R-squared }\end{array}$ & $\begin{array}{l}4,125 \\
\text { NO } \\
0.345\end{array}$ & $\begin{array}{c}4,125 \\
\text { Industry \& Year } \\
0.509\end{array}$ & $\begin{array}{c}3,192 \\
\text { NO } \\
0.348\end{array}$ & $\begin{array}{c}3,192 \\
\text { Industry \& Year } \\
0.525\end{array}$ \\
\hline
\end{tabular}


Panel C: ROA

\begin{tabular}{|c|c|c|c|c|}
\hline \multirow{3}{*}{$\begin{array}{l}\text { VARIABLES } \\
\text { DiD }\end{array}$} & \multicolumn{2}{|c|}{ WHD Violations } & \multicolumn{2}{|c|}{$\underline{\text { FLSA Violations }}$} \\
\hline & 0.001 & -0.004 & -0.003 & -0.011 \\
\hline & $(0.96)$ & $(\mathbf{0 . 8 3})$ & $(0.92)$ & $(0.70)$ \\
\hline \multirow[t]{2}{*}{ Treat } & -0.017 & -0.012 & -0.012 & -0.009 \\
\hline & $(0.35)$ & $(0.39)$ & $(0.57)$ & $(0.62)$ \\
\hline \multirow[t]{2}{*}{ Post } & -0.010 & -0.001 & -0.015 & -0.000 \\
\hline & $(0.64)$ & $(0.90)$ & $(0.56)$ & $(0.98)$ \\
\hline \multirow[t]{2}{*}{ SalesGrowth } & 0.028 & 0.028 & 0.018 & 0.018 \\
\hline & $(0.15)$ & $(0.59)$ & $(0.41)$ & $(0.74)$ \\
\hline \multirow[t]{2}{*}{ size } & $0.028 * * *$ & $0.038 * *$ & $0.035 * * *$ & $0.048 * *$ \\
\hline & $(0.00)$ & $(0.03)$ & $(0.00)$ & $(0.03)$ \\
\hline \multirow[t]{2}{*}{ ForeignIncome } & 0.003 & -0.006 & -0.013 & -0.025 \\
\hline & $(0.85)$ & $(0.72)$ & $(0.43)$ & $(0.29)$ \\
\hline \multirow[t]{2}{*}{ Leverage } & $-0.062 *$ & -0.032 & $-0.078 *$ & $-0.064 *$ \\
\hline & $(0.06)$ & $(0.33)$ & $(0.06)$ & $(0.07)$ \\
\hline \multirow[t]{2}{*}{ CapIntensity } & -0.017 & -0.006 & 0.001 & 0.003 \\
\hline & $(0.60)$ & $(0.91)$ & $(0.98)$ & $(0.96)$ \\
\hline \multirow[t]{2}{*}{ Intangibles } & -0.044 & -0.016 & -0.035 & -0.006 \\
\hline & $(0.22)$ & $(0.67)$ & $(0.44)$ & $(0.92)$ \\
\hline \multirow[t]{2}{*}{ MTB } & $0.009 * * *$ & $0.010^{*}$ & $0.014 * * *$ & $0.014^{*}$ \\
\hline & $(0.00)$ & $(0.09)$ & $(0.00)$ & $(0.09)$ \\
\hline \multirow[t]{2}{*}{$\mathrm{RD}$} & $-1.627 * * *$ & $-1.679 * * *$ & $-1.399 * * *$ & $-1.461 * *$ \\
\hline & $(0.00)$ & $(0.00)$ & $(0.00)$ & $(0.02)$ \\
\hline \multirow[t]{2}{*}{ Adv } & 0.255 & 0.052 & 0.169 & -0.084 \\
\hline & $(0.20)$ & $(0.79)$ & $(0.49)$ & $(0.70)$ \\
\hline \multirow[t]{2}{*}{ Pension } & $0.106 * * *$ & $0.117^{*}$ & $0.109 * * *$ & $0.110 *$ \\
\hline & $(0.00)$ & $(0.06)$ & $(0.00)$ & $(0.08)$ \\
\hline \multirow[t]{2}{*}{ LossFirm } & $-0.217 * * *$ & $-0.203 * * *$ & $-0.217 * * *$ & $-0.201 * * *$ \\
\hline & $(0.00)$ & $(0.00)$ & $(0.00)$ & $(0.00)$ \\
\hline \multirow[t]{2}{*}{ Union } & $-0.072 * * *$ & $-0.079 * *$ & $-0.069 * *$ & $-0.080 * *$ \\
\hline & $(0.00)$ & $(0.01)$ & $(0.05)$ & $(0.04)$ \\
\hline \multirow[t]{2}{*}{ EquityIncome } & $7.270 * * *$ & 6.759 & $9.181 * * *$ & 8.282 \\
\hline & $(0.00)$ & $(0.12)$ & $(0.00)$ & $(0.17)$ \\
\hline \multirow[t]{2}{*}{ stateIncomeTax } & $0.056 * * *$ & $0.055 * *$ & $0.074 * * *$ & $0.069 * *$ \\
\hline & $(0.00)$ & $(0.04)$ & $(0.00)$ & $(0.04)$ \\
\hline \multirow[t]{2}{*}{ Constant } & $-0.242 * * *$ & -0.319 & $-0.319 * * *$ & -0.374 \\
\hline & $(0.00)$ & $(0.17)$ & $(0.00)$ & $(0.16)$ \\
\hline Observations & 4,425 & 4,425 & 3,437 & 3,437 \\
\hline Fixed Effects & NO & Industry \& Year & NO & Industry \& Year \\
\hline Adj. R-squared & 0.151 & 0.152 & 0.153 & 0.152 \\
\hline
\end{tabular}


Table 9: Cross-Sectional Test: Likelihood of Tax Avoidance Sample Partition

This table present results for testing whether the impact of discovering labor violations on firms' CashETR differs for firms who are more likely to engage in higher rates of tax avoidance. The control group includes firms that were subjected to a WHD audit but for which no labor violations were found. $\mathrm{P}$-values are presented in parentheses. $* * *, * *, *$ denote significance at $1 \%, 5 \%$, and 10\%. Detailed variable definitions are presented in Appendix 1.

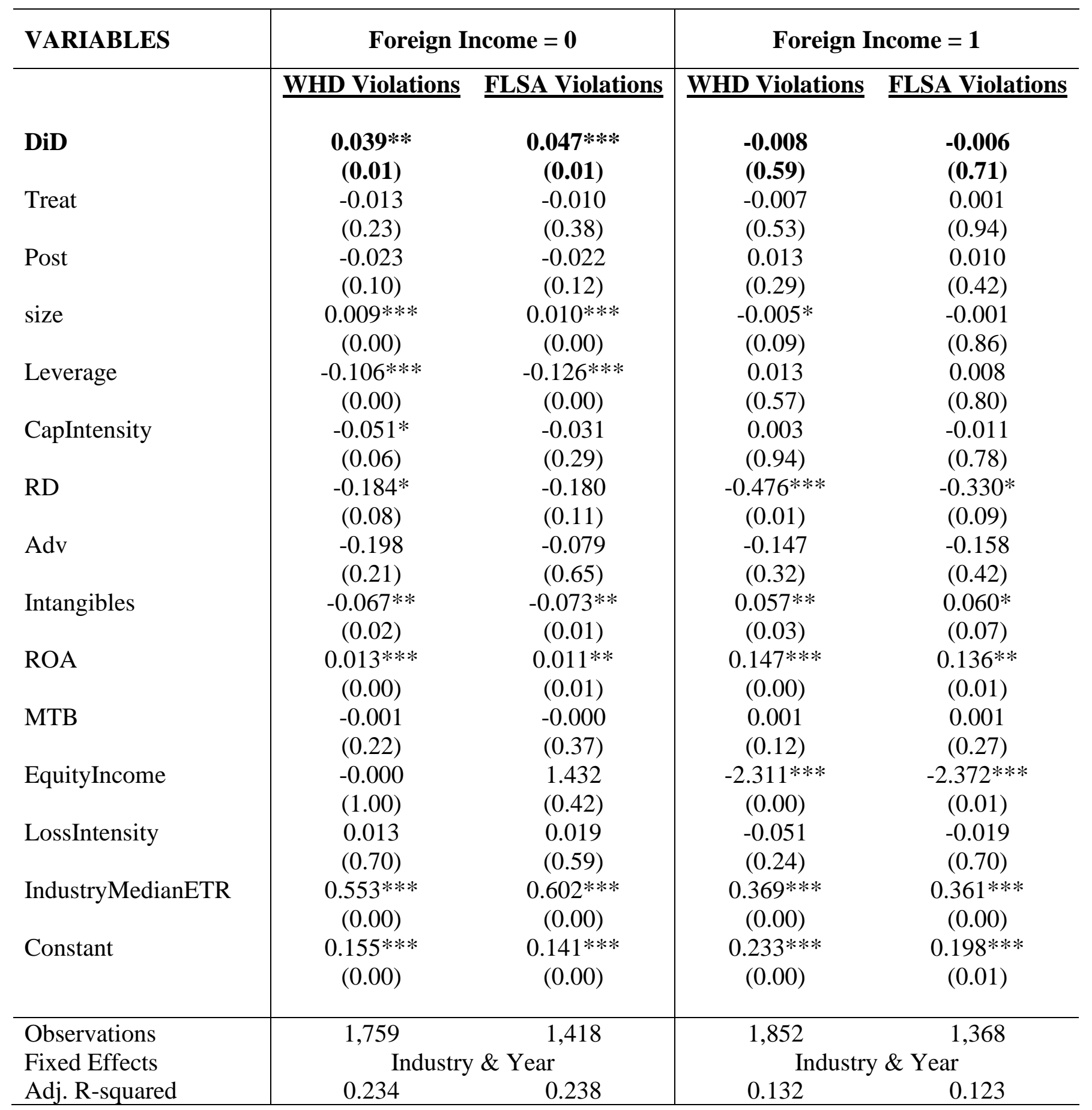




\section{Table 10: Robustness Tests}

\section{Panel A: Change in CashETR PSM-Matched Sample}

This table presents results for Equation (3) which tests the impact of discovering labor violations on firms' Cash ETR. The control group includes propensity score-matched industry-year firms based on the controls from the first stage Heckman Model in Table 4. Control firms have not been audited. I perform 1 to 1 nearest neighbor matching within a .25 caliper width without replacement. P-values are presented in parentheses. $* * *, * *, *$ denote significance at $1 \%, 5 \%$, and $10 \%$ levels, respectively. Detailed variable definitions are presented in Appendix 1.

\begin{tabular}{|c|c|c|c|}
\hline Variables & Audit & WHD Violations & FLSA Violations \\
\hline DiD & $\begin{array}{l}0.007 \\
(0.40)\end{array}$ & $\begin{array}{l}0.016 \\
(0.12)\end{array}$ & $\begin{array}{c}0.023 * \\
(0.07)\end{array}$ \\
\hline Treat & $\begin{array}{c}0.013 * * \\
(0.02)\end{array}$ & $\begin{array}{l}0.009 \\
(0.19)\end{array}$ & $\begin{array}{c}0.018 * * \\
(0.02)\end{array}$ \\
\hline Post & $\begin{array}{c}-0.003 \\
(0.62)\end{array}$ & $\begin{array}{c}-0.006 \\
(0.43)\end{array}$ & $\begin{array}{r}-0.007 \\
(0.42)\end{array}$ \\
\hline size & $\begin{array}{c}0.005 * * * \\
(0.00)\end{array}$ & $\begin{array}{c}0.004 * * \\
(0.01)\end{array}$ & $\begin{array}{c}0.007 * * * \\
(0.00)\end{array}$ \\
\hline ForeignIncome & $\begin{array}{c}0.022 * * * \\
(0.00)\end{array}$ & $\begin{array}{c}0.021 * * * \\
(0.00)\end{array}$ & $\begin{array}{c}0.020 * * * \\
(0.00)\end{array}$ \\
\hline Leverage & $\begin{array}{c}-0.081 * * * \\
(0.00)\end{array}$ & $\begin{array}{c}-0.061 * * * \\
(0.00)\end{array}$ & $\begin{array}{c}-0.083 * * * \\
(0.00)\end{array}$ \\
\hline CapIntensity & $\begin{array}{c}-0.046 * * * \\
(0.00)\end{array}$ & $\begin{array}{c}-0.045 * * * \\
(0.00)\end{array}$ & $\begin{array}{c}-0.037 * * \\
(0.03)\end{array}$ \\
\hline $\mathrm{RD}$ & $\begin{array}{c}-0.572 * * * \\
(0.00)\end{array}$ & $\begin{array}{c}-0.605 * * * \\
(0.00)\end{array}$ & $\begin{array}{c}-0.613 * * * \\
(0.00)\end{array}$ \\
\hline Adv & $\begin{array}{c}0.008 \\
(0.90)\end{array}$ & $\begin{array}{l}0.005 \\
(0.96)\end{array}$ & $\begin{array}{l}0.099 \\
(0.35)\end{array}$ \\
\hline Intangibles & $\begin{array}{c}0.024^{*} \\
(0.06)\end{array}$ & $\begin{array}{c}0.018 \\
(0.24)\end{array}$ & $\begin{array}{l}0.013 \\
(0.50)\end{array}$ \\
\hline ROA & $\begin{array}{c}0.039 * * * \\
(0.00)\end{array}$ & $\begin{array}{c}0.145^{* * *} \\
(0.00)\end{array}$ & $\begin{array}{c}0.142 * * * \\
(0.00)\end{array}$ \\
\hline MTB & $\begin{array}{c}-0.000 \\
(0.26)\end{array}$ & $\begin{array}{c}-0.000 \\
(0.45)\end{array}$ & $\begin{array}{r}-0.001 \\
(0.16)\end{array}$ \\
\hline EquityIncome & $\begin{array}{c}0.021 \\
(0.97)\end{array}$ & $\begin{array}{l}-0.496 \\
(0.42)\end{array}$ & $\begin{array}{l}-0.019 \\
(0.98)\end{array}$ \\
\hline LossIntensity & $\begin{array}{c}0.003 \\
(0.80)\end{array}$ & $\begin{array}{c}-0.009 \\
(0.47)\end{array}$ & $\begin{array}{c}-0.018 \\
(0.25)\end{array}$ \\
\hline IndustryMedianETR & $\begin{array}{c}0.373 * * * \\
(0.00)\end{array}$ & $\begin{array}{c}0.376 * * * \\
(0.00)\end{array}$ & $\begin{array}{c}0.331 * * * \\
(0.00)\end{array}$ \\
\hline Constant & $\begin{array}{c}0.158 * * * \\
(0.00)\end{array}$ & $\begin{array}{c}0.156^{* * *} \\
(0.00)\end{array}$ & $\begin{array}{c}0.145^{* * *} * \\
(0.00)\end{array}$ \\
\hline $\begin{array}{l}\text { Observations } \\
\text { Fixed Effects } \\
\text { Adj. R-squared }\end{array}$ & $\begin{array}{c}5,583 \\
\text { NO } \\
0.0886\end{array}$ & $\begin{array}{c}3,880 \\
\text { NO } \\
0.106\end{array}$ & $\begin{array}{c}2,595 \\
\mathrm{NO} \\
0.120\end{array}$ \\
\hline
\end{tabular}




\section{Panel B: Change in CashETR with an Alternative Control Group}

This table presents results for Equation (3) which tests the impact of discovering labor violations on firms' Cash ETR with an alternative control group. The control group includes firms that were subjected to a WHD audit but for which no FLSA labor violations were found. P-values are presented in parentheses. $* * *, * * *$ denote significance at $1 \%, 5 \%$, and $10 \%$ levels, respectively. Detailed variable definitions are presented in Appendix 1.

\begin{tabular}{|c|c|c|}
\hline Variables & \multicolumn{2}{|c|}{ FLSA Violations } \\
\hline DiD & $\begin{array}{c}0.025^{* *} \\
(0.01)\end{array}$ & $\begin{array}{c}0.022 * * \\
(0.03)\end{array}$ \\
\hline Treat & $\begin{array}{c}-0.000 \\
(0.98)\end{array}$ & $\begin{array}{r}-0.002 \\
(0.83)\end{array}$ \\
\hline Post & $\begin{array}{c}-0.008 \\
(0.24)\end{array}$ & $\begin{array}{c}-0.002 \\
(0.81)\end{array}$ \\
\hline size & $\begin{array}{l}0.002 \\
(0.27)\end{array}$ & $\begin{array}{c}0.005 * * \\
(0.01)\end{array}$ \\
\hline ForeignIncome & $\begin{array}{c}0.024 * * * \\
(0.00)\end{array}$ & $\begin{array}{c}0.026 * * * \\
(0.00)\end{array}$ \\
\hline Leverage & $\begin{array}{c}-0.065^{* * * *} \\
(0.00)\end{array}$ & $\begin{array}{c}-0.061 * * * \\
(0.00)\end{array}$ \\
\hline CapIntensity & $\begin{array}{c}-0.035 * * * \\
(0.01)\end{array}$ & $\begin{array}{c}-0.036^{*} \\
(0.08)\end{array}$ \\
\hline $\mathrm{RD}$ & $\begin{array}{c}-0.255^{* * *} * \\
(0.00)\end{array}$ & $\begin{array}{c}-0.246 * * \\
(0.02)\end{array}$ \\
\hline Adv & $\begin{array}{r}-0.067 \\
(0.45)\end{array}$ & $\begin{array}{c}-0.198^{*} \\
(0.06)\end{array}$ \\
\hline Intangibles & $\begin{array}{l}0.001 \\
(0.94)\end{array}$ & $\begin{array}{l}0.013 \\
(0.48)\end{array}$ \\
\hline ROA & $\begin{array}{c}0.022 * * * \\
(0.00)\end{array}$ & $\begin{array}{c}0.019 * * * \\
(0.00)\end{array}$ \\
\hline МТB & $\begin{array}{c}-0.000 \\
(0.23)\end{array}$ & $\begin{array}{c}-0.000 \\
(0.60)\end{array}$ \\
\hline EquityIncome & $\begin{array}{c}-0.698 \\
(0.27)\end{array}$ & $\begin{array}{c}-1.586^{* * * *} \\
(0.01)\end{array}$ \\
\hline LossIntensity & $\begin{array}{l}0.014 \\
(0.29)\end{array}$ & $\begin{array}{c}-0.033 \\
(0.22)\end{array}$ \\
\hline IndustryMedianETR & $\begin{array}{c}0.414 * * * \\
(0.00)\end{array}$ & $\begin{array}{c}0.528 * * * \\
(0.00)\end{array}$ \\
\hline Constant & $\begin{array}{c}0.181 * * * \\
(0.00)\end{array}$ & $\begin{array}{c}0.142 * * * \\
(0.00)\end{array}$ \\
\hline $\begin{array}{l}\text { Observations } \\
\text { Fixed Effects } \\
\text { Adj. R-squared }\end{array}$ & $\begin{array}{c}3,611 \\
\mathrm{NO} \\
0.0900\end{array}$ & $\begin{array}{c}3,611 \\
\text { Industry \& Year } \\
0.153\end{array}$ \\
\hline
\end{tabular}




\section{Panel C: Change in CashETR with an Alternative Treatment Group}

This table presents results for Equation (3) which tests the impact of discovering labor violations on firms' Cash ETR with an alternative treatment group. The treatment group includes firms that were subjected to a WHD audit and were found to have minimum wage violations. P-values are presented in parentheses. $* * *, * * *$ denote significance at $1 \%, 5 \%$, and $10 \%$ levels, respectively. Detailed variable definitions are presented in Appendix 1.

\begin{tabular}{|c|c|c|c|c|}
\hline \multirow{2}{*}{$\begin{array}{l}\text { Variables } \\
\text { DiD }\end{array}$} & \multicolumn{2}{|c|}{$\begin{array}{c}\text { Control Group as Audits with } \\
\text { Zero FLSA Min Wage } \\
\text { Violations }\end{array}$} & \multicolumn{2}{|c|}{$\begin{array}{c}\text { Control Group as Audits without } \\
\text { Labor Violations }\end{array}$} \\
\hline & $\begin{array}{c}0.048 * * \\
(0.02)\end{array}$ & $\begin{array}{c}0.046 * * \\
(0.04)\end{array}$ & $\begin{array}{c}0.045 * * \\
(0.03)\end{array}$ & $\begin{array}{c}0.043 * * \\
(0.05)\end{array}$ \\
\hline Treat & $\begin{array}{l}0.010 \\
(0.51)\end{array}$ & $\begin{array}{l}0.008 \\
(0.68)\end{array}$ & $\begin{array}{l}0.009 \\
(0.57)\end{array}$ & $\begin{array}{l}0.008 \\
(0.66)\end{array}$ \\
\hline Post & $\begin{array}{l}-0.001 \\
(0.83)\end{array}$ & $\begin{array}{l}0.004 \\
(0.52)\end{array}$ & $\begin{array}{l}0.000 \\
(0.98)\end{array}$ & $\begin{array}{l}0.004 \\
(0.54)\end{array}$ \\
\hline size & $\begin{array}{l}0.002 \\
(0.26)\end{array}$ & $\begin{array}{c}0.005 * * \\
(0.01)\end{array}$ & $\begin{array}{c}0.006 * * * \\
(0.00)\end{array}$ & $\begin{array}{c}0.008 * * * \\
(0.00)\end{array}$ \\
\hline ForeignIncome & $\begin{array}{l}0.024 * * * \\
(0.00)\end{array}$ & $\begin{array}{l}0.026 * * * \\
(0.00)\end{array}$ & $\begin{array}{l}0.026 * * * \\
(0.00)\end{array}$ & $\begin{array}{l}0.030 * * * \\
(0.00)\end{array}$ \\
\hline Leverage & $\begin{array}{c}-0.064 * * * \\
(0.00)\end{array}$ & $\begin{array}{c}-0.062 * * * \\
(0.00)\end{array}$ & $\begin{array}{c}-0.081 * * * \\
(0.00)\end{array}$ & $\begin{array}{c}-0.085 * * * \\
(0.00)\end{array}$ \\
\hline CapIntensity & $\begin{array}{c}-0.037 * * * \\
(0.01)\end{array}$ & $\begin{array}{c}-0.037 * \\
(0.07)\end{array}$ & $\begin{array}{c}-0.037 * * \\
(0.02)\end{array}$ & $\begin{array}{r}-0.037 \\
(0.11)\end{array}$ \\
\hline $\mathrm{RD}$ & $\begin{array}{l}-0.257 * * * \\
(0.00)\end{array}$ & $\begin{array}{c}-0.245^{* *} \\
(0.02)\end{array}$ & $\begin{array}{l}-0.216 * * * \\
(0.01)\end{array}$ & $\begin{array}{c}-0.205^{* *} \\
(0.04)\end{array}$ \\
\hline$A d v$ & $\begin{array}{l}-0.065 \\
(0.46)\end{array}$ & $\begin{array}{c}-0.178 * \\
(0.10)\end{array}$ & $\begin{array}{l}0.004 \\
(0.97)\end{array}$ & $\begin{array}{l}-0.104 \\
(0.40)\end{array}$ \\
\hline Intangibles & $\begin{array}{l}0.004 \\
(0.81)\end{array}$ & $\begin{array}{l}0.016 \\
(0.39)\end{array}$ & $\begin{array}{c}-0.002 \\
(0.89)\end{array}$ & $\begin{array}{l}0.007 \\
(0.76)\end{array}$ \\
\hline ROA & $\begin{array}{c}0.022 * * * \\
(0.00)\end{array}$ & $\begin{array}{c}0.019 * * * \\
(0.00)\end{array}$ & $\begin{array}{c}0.018 * * * \\
(0.00)\end{array}$ & $\begin{array}{c}0.015^{* * *} * \\
(0.00)\end{array}$ \\
\hline MTB & $\begin{array}{c}-0.000 \\
(0.26)\end{array}$ & $\begin{array}{r}-0.000 \\
(0.64)\end{array}$ & $\begin{array}{c}-0.001 \\
(0.19)\end{array}$ & $\begin{array}{l}-0.000 \\
(0.70)\end{array}$ \\
\hline EquityIncome & $\begin{array}{l}-0.582 \\
(0.36)\end{array}$ & $\begin{array}{c}-1.482 * * \\
(0.01)\end{array}$ & $\begin{array}{l}-0.062 \\
(0.94)\end{array}$ & $\begin{array}{r}-1.164 \\
(0.12)\end{array}$ \\
\hline LossIntensity & $\begin{array}{l}0.015 \\
(0.25)\end{array}$ & $\begin{array}{c}-0.034 \\
(0.21)\end{array}$ & $\begin{array}{l}0.016 \\
(0.30)\end{array}$ & $\begin{array}{r}-0.021 \\
(0.47)\end{array}$ \\
\hline IndustryMedianETR & $\begin{array}{c}0.407 * * * \\
(0.00)\end{array}$ & $\begin{array}{l}0.521 * * * \\
(0.00)\end{array}$ & $\begin{array}{l}0.407 * * * \\
(0.00)\end{array}$ & $\begin{array}{c}0.540 * * * \\
(0.00)\end{array}$ \\
\hline Constant & $\begin{array}{c}0.182 * * * \\
(0.00)\end{array}$ & $\begin{array}{c}0.142 * * * \\
(0.00)\end{array}$ & $\begin{array}{c}0.155^{* * * *} \\
(0.00)\end{array}$ & $\begin{array}{c}0.124 * * * \\
(0.00)\end{array}$ \\
\hline $\begin{array}{l}\text { Observations } \\
\text { Fixed Effects } \\
\text { Adj. R-squared }\end{array}$ & $\begin{array}{l}3,611 \\
\text { NO } \\
0.0928\end{array}$ & $\begin{array}{c}3,611 \\
\text { Industry \& Year } \\
0.156\end{array}$ & $\begin{array}{c}2,786 \\
\text { NO } \\
0.102\end{array}$ & $\begin{array}{c}2,786 \\
\text { Industry \& Year } \\
0.159\end{array}$ \\
\hline
\end{tabular}

